UNIVERSIDADE DE SÃO PAULO

FACULDADE DE ZOOTECNIA E ENGENHARIA DE ALIMENTOS

DÉBORA ROSCHE FERREIRA PLANELLO

Estudo exploratório do mercado da tilápia no estado de São Paulo

Pirassununga SP

2015 
DÉBORA ROSCHE FERREIRA PLANELLO

Estudo exploratório do mercado da tilápia no estado de São Paulo

Versão corrigida

Dissertação apresentada à Faculdade de Zootecnia e Engenharia de Alimentos da Universidade de São Paulo, como parte dos requisitos para a obtenção do Título de Mestre em Ciências.

Área de Concentração: Gestão e Inovação na Indústria Animal

Orientador: Prof. Dr. Augusto Hauber Gameiro

\section{Pirassununga SP}


Dados Internacionais de Catalogação na Publicação

Serviço de Biblioteca e Informação da Faculdade de Zootecnia e Engenharia de Alimentos da Universidade de São Paulo

Planello, Débora Rosche Ferreira Estudo exploratório do mercado da tilápia no estado de São Paulo / Débora Rosche Ferreira Planello. -Pirassununga, 2015.

$102 \mathrm{f}$. Dissertação (Mestrado) -- Faculdade de Zootecnia e Engenharia de Alimentos - Universidade de São Paulo. Departamento de Nutrição e Produção Animal. Área de Concentração: Gestão e Inovação na Indústria Animal.

Orientador: Prof. Dr. Augusto Hauber Gameiro.

1. Oferta 2. Demanda 3. Mercado 4. Tilapicultura

5. Piscicultura. I. Título. 
Dedico a...

Minha mãe Suzete Koki Rosche Ferreira, Meu pai Desidério Ferreira Neto e Meu esposo Marcos Bastos Planello, Pelo amor, incentivo e paciência. 


\section{AGRADECIMENTOS}

Em primeiro lugar, agradeço ao meu orientador Prof. Dr. Augusto Hauber Gameiro por ter me oferecido a oportunidade de cursar o mestrado profissional na FZEA/USP. Mais do que isso, pelo seu apoio à minha vontade de me tornar uma profissional do setor do pescado, pelos seus ensinamentos, dedicação ao meu crescimento e desenvolvimento, compreensão à minha personalidade e limitações, pelo seu eterno apoio.

Ao meu esposo Marcos pelo incentivo à realização de mais esta etapa em minha vida. Pelas horas no final de semana que me esperava enquanto eu assistia às aulas, pelas vezes que fez a cotação da tilápia por mim, pela compreensão dos momentos em que eu precisava focar nas leituras e escrita deste projeto, o meu muito obrigada.

Aos meus pais que desde sempre se esforçaram para me oferecer a melhor educação e saúde para eu correr atrás dos meus sonhos e felicidade.

Aos meus amigos que me apoiaram de diferentes formas na realização deste trabalho, mas, em especial, Alejandro Ojeda, Luciana Kimie Savay da Silva, Rafael Barone e Daniel Sonoda.

Aos professores do curso do mestrado profissional em Gestão e Inovação na Indústria Animal, à Profa Dra Marisa d'Arce pelo incentivo e palavras tão sábias, à Profa Dra Marília Oetterer pela sementinha que plantou em meu coração durante as aulas de graduação e que é a motivação que tenho até hoje para trabalhar pelo desenvolvimento da cadeia do pescado brasileira.

Aos colegas da primeira turma do Mestrado Profissional em Gestão e Inovação na Indústria Animal da FZEA pelo conhecimento compartilhado e pela companhia durante as aulas às 6as feiras a noite e sábado pela manhã e tarde.

Aos profissionais e empresas que colaboraram para a realização desta pesquisa, em especial a FIESP, em nome de Roberto Imai, que me recebeu durante as reuniões em São Paulo e me possibilitou aproximar do setor. 


\section{RESUMO}

PLANELLO, D.R.F. Estudo exploratório do mercado da tilápia no Estado de São Paulo. 2015. Dissertação (Mestrado) - Faculdade de Zootecnia e Engenharia de Alimentos, Universidade de São Paulo, Pirassununga, 2015.

O presente trabalho teve como objetivo desenvolver um estudo exploratório sobre o mercado da tilápia no estado de São Paulo, identificando os tipos de produtos oferecidos, estimando as quantidades comercializadas e consumidas, analisando os preços dos produtos e propondo melhorias no processo de comercialização. Para tanto, os determinantes de oferta e demanda foram levantados por meio de duas abordagens, uma exploratória e outra descritiva, baseadas em dados primários e secundários. Além das consultas feitas às referências disponíveis na literatura, pesquisas a campo, entrevistas e aplicação de questionário junto a consumidores foram realizadas. Para a análise dos resultados obtidos, a teoria da organização industrial (OI) foi utilizada para auxiliar nas conclusões de como os processos de mercado estão orientando os produtores a atenderem a demanda por tilápia, o que parece está falhando, e o que poderia ser ajustado para atingir um padrão satisfatório. Em suma, o estado de São Paulo produz aproximadamente 50.000 t de tilápia anualmente e, os seus consumidores consomem menos de $100 \mathrm{~g}$ de tilápia por semana. O estado é o quarto maior consumidor desta espécie de peixe, segundo dados da Pesquisa de Orçamento Familiar de 2008-2009 e o maior consumo está concentrado nas classes com renda abaixo de $R \$ 2.490,00$. O produto mais comercializado e consumido é a tilápia inteira e o motivo mais apontado por consumidores como sendo a causa de não consumirem mais foi "não ter o hábito de comprar". Além dessas conclusões, verificou-se que o país ainda não participa de forma significativa do mercado exportador de tilápia, apesar de uma demanda internacional grande e crescente, principalmente pelos Estados Unidos. Considerando que a carne desta espécie de peixe é bem aceita pelos consumidores devido suas características nutricionais, sensoriais e ausência de espinhas em "Y", e considerando as perspectivas do varejo, conclui-se que a demanda interna deve 
aumentar nos próximos anos. Há oportunidade de reduzir o custo de produção, elevar a rentabilidade da indústria via aproveitamento dos subprodutos e investir em processamento e inovação para atender às exigências do consumidor. Para tanto, é preciso que mais dados e estatísticas sejam gerados, com maior periodicidade, para que pesquisas e análises de viabilidade de negócios e investimentos sejam possíveis de serem realizadas, refletindo a realidade e permitindo projeções mais plausíveis. 
Palavras-chave: oferta, demanda, mercado, tilapicultura, piscicultura

\section{ABSTRACT}

This study aimed to develop an exploratory study on the tilapia market in the state of Sao Paulo, identifying the types of products offered, estimating the quantities sold and consumed, analyzing the product's prices and proposing improvements in the commercialization process. Therefore the supply and demand determinants were raised through two approaches, exploratory and other descriptive, based on primary and secondary data. In addition to the research on the references available in the literature, field research, interviews, and an application of questionnaires to endconsumers were carried out. From the analysis of the results obtained, the industrial organization theory was used to aid the findings of how market processes are driving producers to meet the demand for tilapia, what seems to be failing, and what should be adjusted to an ideal standard. In short, the state of Sao Paulo produces about $50.000 \mathrm{t}$ tilapia annually and the population consumes, generally less than $100 \mathrm{~g}$ of tilapia per week. The state is the fourth largest consumer of this kind of fish, according to the Household Budget Survey of 2008-2009, and the highest consumption is concentrated in the classes with income below $R \$ 2,490.00$. The product most marketed and consumed is the whole tilapia, and the reason most mentioned by consumers as being the cause of not consuming more was "not have the habit of buying". In addition to these conclusions, it was found that the country still does not participate significantly in the tilapia exporter market, despite a large and growing international demand, especially by the United States. Whereas the meat of this fish species is well accepted by consumers because of its nutritional characteristics, sensory and absence of spines on " $Y$ " and, considering the retail perspective, it is concluded that the domestic demand for this fish shall increase in the coming years. There is an opportunity to reduce production costs, increase profitability via the use of industrial by-products and investments in processing and innovation to meet consumer demands. Therefore, it is necessary that more data and statistics are generated with greater frequency, so that the research and business feasibility analysis and investment in this sector are able to be made, reflecting the reality and allowing projections more plausible.

Keywords: supply, demand, market, fish farming, tilapia 


\section{LISTA DE ILUSTRAÇÕES}

Figura 1 - Porcentagem de participação dos diferentes sistemas de produção de pescado no Brasil

Figura 2 - Ranking mundial de produção de pescado de pesca extrativa e aquicultura, em toneladas.

Figura 3 - Produção Nacional de Tilápia de 2008 a 2011 em toneladas....................................23

Figura 4 - Distribuição regional da produção de Tilápia ..........................................................24

Figura 5 - Vendas totais e de tilápia, mês a mês, de 2011 a2013, na peixaria de uma rede de

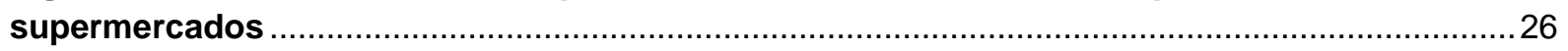

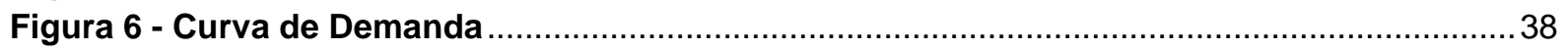

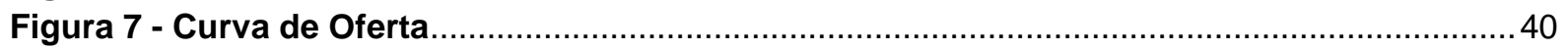

Figura 8 - Representação esquemática do Sistema Agroindustrial da Tilápia no estado de São

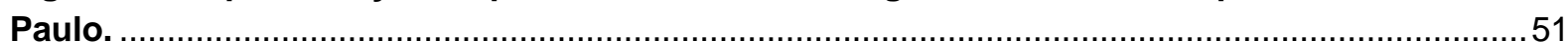

Figura 9 - Histórico de preço real (dez/2014) e volume (em kg) de tilápia inteira comercializada

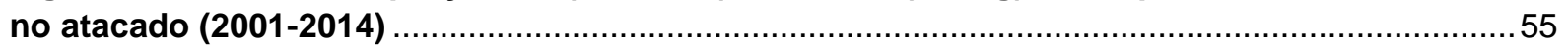

Figura 10 - Sazonalidade de venda (em kg) de tilápia no atacado (2011-2014) .....................56 Figura 11 - Comparação entre venda (em kg) de pescado no varejo e tilápia no atacado e no

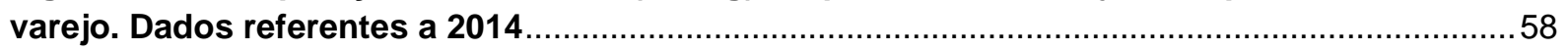
Figura 12 - Idade dos participantes da pesquisa com consumidores no estado de São Paulo. 66 Figura 13 - Renda dos participantes da pesquisa com consumidores no estado de São Paulo 66

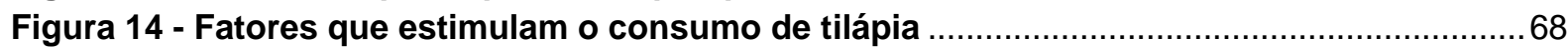
Figura 15 - Fatores que levariam a um maior consumo de tilápia ....................................... 70 Figura 16 - Motivos que levam o consumidor a não consumir mais tilápia ............................71 Figura 17 - Preço real (dez/2014) por kg de tilápia inteira comercializada no atacado de 2011 a

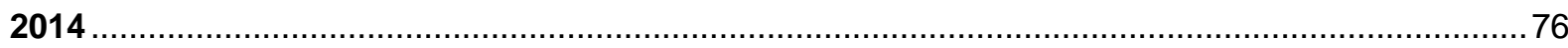
Figura 18 - Preço por kg de tilápia inteira comercializada na CEAGESP de janeiro a abril de 2015

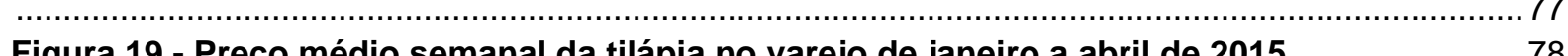

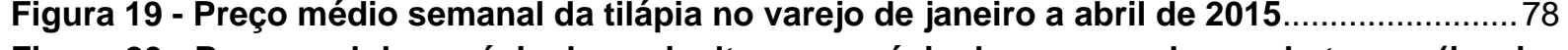

Figura 20 - Preço real de espécie de aquicultura x espécie de pesca ao longo do tempo (janeiro

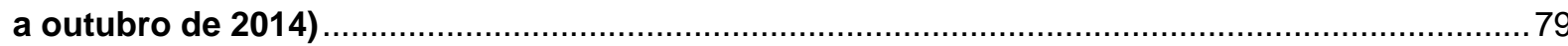
Figura 21 - Comportamento dos preços deflacionados médios mensais do filé de tilápia congelado e fresco no varejo na cidade de Piracicaba/SP 80 


\section{LISTA DE TABELAS}

Tabela 1 - Ranking mundial de produção de pescado em toneladas.

Tabela 2 - Produção aquícola continental 2011 - por Regiões e Unidades da Federação ........... 2

Tabela 3 - Produção nacional de pescado $(t)$ da aquicultura continental por espécie................. 22

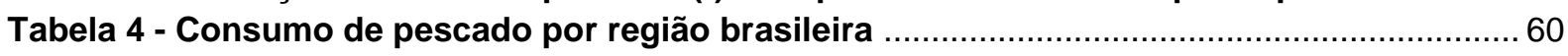

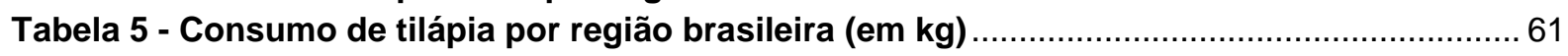

Tabela 6 - Consumo de tilápia no Brasil por faixa de renda .................................................... 63

Tabela 7 - Consumo de tilápia no Brasil, por tipo de produto, por faixa de renda .....................64

Tabela 8 - Tipo de produto adquirido pelo consumidor paulista ........................................... 70

Tabela 9 - Preço do kg de tilápia na última compra realizada por consumidores paulistas ....... 71

Tabela 10 - Substituição de tilápia na hora da compra por outras proteínas ……....................... 73

Tabela 11 - Resultados da análise de correlação entre os preços da tilápia e das demais espécies

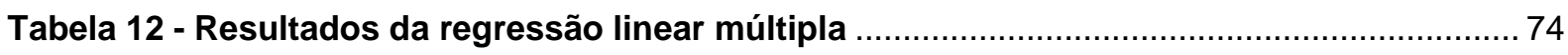

Tabela 13 - Histórico de importação de tilápia pelos Estados Unidos (em t) ............................ 83

Tabela 14 - Exportação de tilápia do Brasil para os Estados Unidos, por produto, por ano, em t

Tabela 15 - Análise do preço de aquisição do salmão e da tilápia pelo varejo em 2014. 


\section{SUMÁRIO}

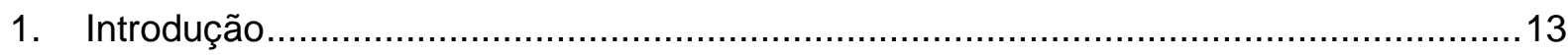

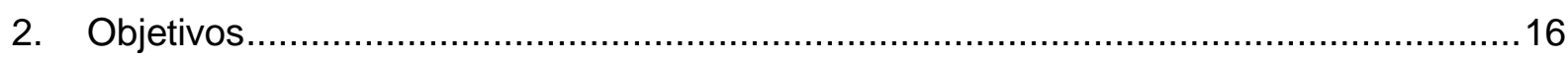

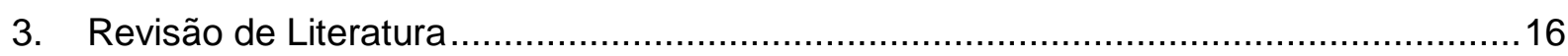

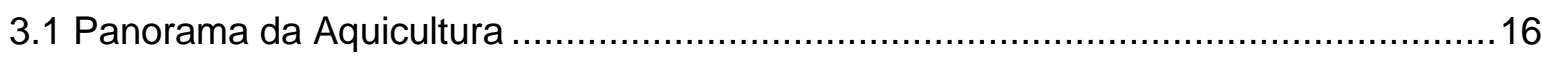

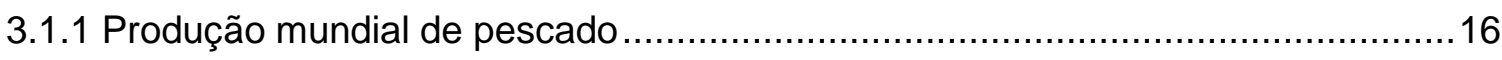

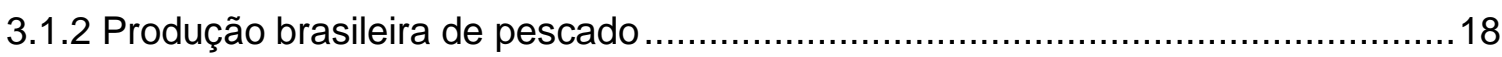

3.1.3 Tilapicultura no Brasil e no Estado de São Paulo ..............................................21

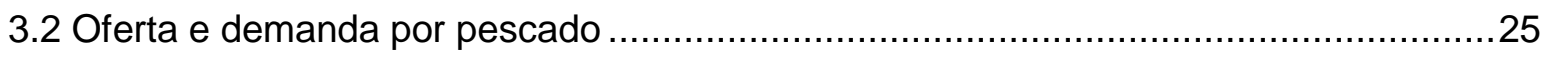

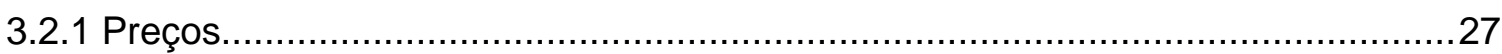

3.2.2 Tecnologia e aproveitamento de resíduos.......................................................29

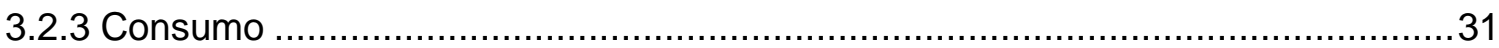

3.3 Mercado e Teoria Econômica.............................................................................

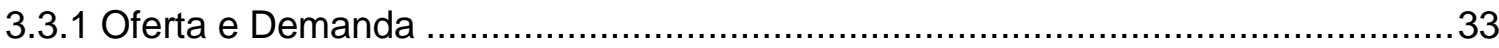

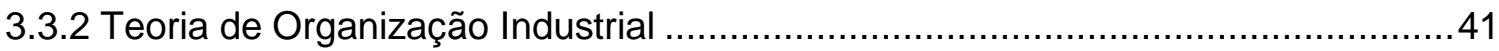

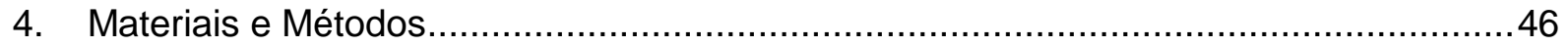

5. Resultados e Discussão............................................................................

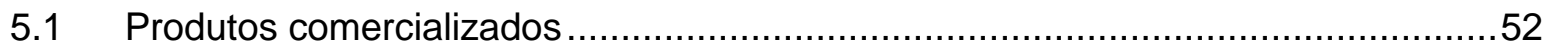

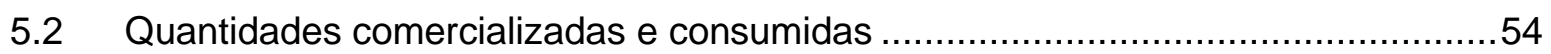

5.2.1 Quantidades comercializadas no atacado.....................................................

5.2.2 Quantidades comercializadas no varejo ……….........................................56

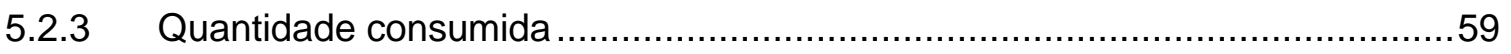

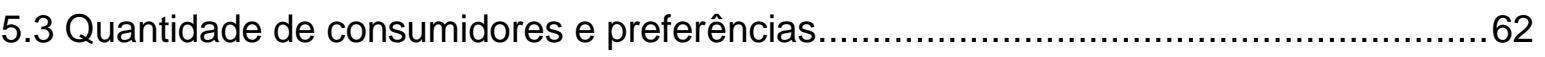

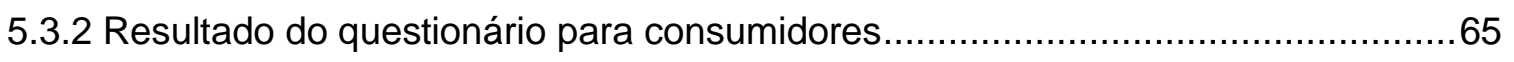

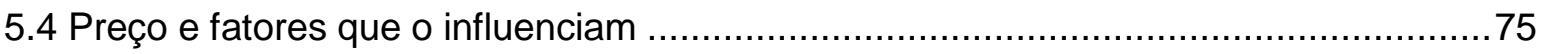

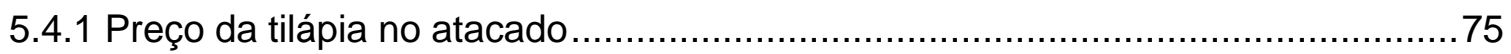

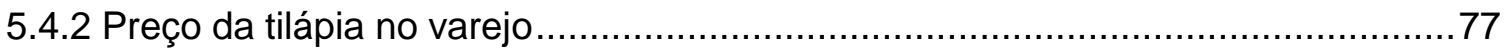

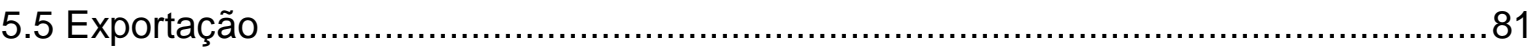

5.6 Oportunidades de melhoria na comercialização de tilápia .........................................86

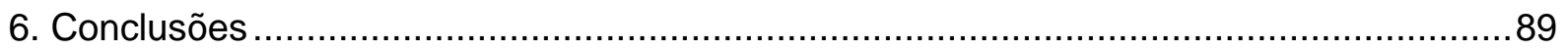

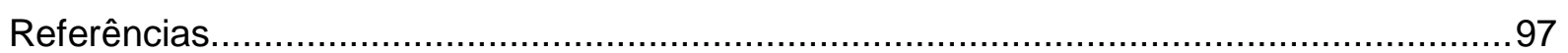




\section{Introdução}

O Brasil é um país que se destaca mundialmente na produção de proteína animal de qualidade, como é o caso da carne bovina, carne suína e de frango. Porém, na área de pescado, proteína animal mais consumida no mundo e com alto valor nutricional, o país ainda não é um fornecedor de destaque, apesar de possuir vantagens na produção e no fornecimento deste alimento.

O desafio de alimentar bilhões de pessoas envolve especialistas em diferentes áreas, de diferentes países e o Brasil é um deles. Devido à sua extensão e disponibilidade de recursos hídricos, há no país um potencial de crescimento da aquicultura continental e, consequentemente, uma expectativa de que o Brasil se torne, além de um grande fornecedor de grãos e de outras proteínas animais, um importante produtor e exportador de pescado.

Assim, para o Brasil atingir o patamar de grande fornecedor de pescado e concorrer com competitividade com outros países produtores, é preciso que pesquisas, investimentos e ações sejam realizadas em prol da atividade. A tilápia, uma vez que tem uma boa aceitação nacional e internacional, é uma das espécies que merece mais estudos para se ter um panorama concreto do mercado, além de informações para investimentos e definição de estratégias para o crescimento do setor.

A produção de pescado pode se dar por meio de cultivo (aquicultura) ou extrativismo (pesca). Todavia é a aquicultura que tem se destacado e crescido significativamente em diversas nações. No Brasil não é diferente. O país possui diversas espécies de pescado de água doce e água salgada, e uma das que mais tem atraído a atenção dos produtores, investidores e pesquisadores é a Tilápia do Nilo ("Oreochromis niloticus"), espécie de origem africana cuja produção firmou-se como atividade empresarial no Brasil a partir da década de 1980.

O estado de São Paulo é um dos três maiores produtores desta espécie de peixe. Com este trabalho pretende-se estudar o mercado estadual, apresentar os resultados sobre as características da oferta e da demanda para o consumidor final, além de identificar oportunidades de melhoria na comercialização dos produtos de origem desta espécie. Dessa forma, o estudo poderá auxiliar os agentes do setor nas suas 
tomadas de decisão e investimentos, visando o desenvolvimento sustentável desse mercado.

A tilapicultura teve início expressivo no estado de São Paulo na década de 90 e o foco era abastecer os pesque-pague. Contudo, devido aos avanços tecnológicos, a tilápia atingiu um novo patamar e é uma das espécies de peixe mais apreciadas pelo consumidor devido ao seu sabor suave, carne branca e ausência de espinhas em "Y".

Portanto, além de ser uma espécie utilizada para fins de lazer e esporte, é um produto rico para ser fornecido para alimentação humana no mercado nacional e internacional. Apesar disso, no Brasil a tilápia ainda não é ofertada em grande escala aos canais de distribuição, quando comparada a outras proteínas animais.

Entretanto, nota-se no país um crescimento desde 2005 no volume de tilápia produzido. De acordo com os dados oficiais, entre 2000 e 2010 a produção de tilápia cresceu em média 17\% ao ano, mais do que o crescimento médio de 10\% experimentado pela aquicultura no geral, sendo que a espécie já representa $47 \%$ da produção da piscicultura brasileira.

Esse desenvolvimento se deve, dentre outras, às características que permitem o cultivo e, em alguns casos, a produção de dois ciclos por ano, o que ajuda a tornar a atividade rentável e atrativa para os produtores. A produção está presente em quase todos os estados brasileiros. Apesar do cenário favorável e em expansão, esta cadeia agroindustrial enfrenta desafios logísticos, legais e comerciais, que têm dificultado a maior oferta ao consumidor final em todo o território nacional.

Dentre os desafios comerciais pode-se citar a falta de conhecimento dos volumes exatos comercializados e dos preços praticados no mercado físico. Além disso, os tipos de produtos, a demanda e o perfil dos clientes ainda não são plenamente conhecidos. Os produtores de tilápia são independentes e a maioria trabalha com volumes pequenos, o que dificulta a negociação com grandes redes de distribuição.

Essa falta de informações e do entendimento da dinâmica deste mercado prejudicam a identificação das oportunidades e alternativas de produção, tanto para o desenvolvimento dos negócios existentes, quanto o investimento em novos projetos, a criação de políticas públicas e o ganho de competividade. 
Conhecer o mercado de tilápia permite entender o comportamento e as exigências do cliente final da cadeia, identificar os gargalos, e assim, orientar as estratégias das empresas fornecedoras de tais produtos. Com isso, pode-se estruturar e investir em ações que atenderão de forma satisfatória as demandas do público-alvo e mesmo expandir e diversificar os negócios.

O mercado de pescado no Brasil ainda não é amplamente estudado. Mais raros ainda são os trabalhos nessa área sobre uma espécie de peixe específica. Nesta pesquisa, o modelo de oferta e demanda, que é uma ferramenta central de análise econômica, será utilizado como concepção teórica para descrever o mercado da tilápia no estado de São Paulo, e sistematizar dados para a caracterização do setor produtivo.

O estado de São Paulo foi escolhido para este estudo pela sua importância econômica. Além disso, o estado possui grandes empresas processadoras instaladas principalmente no oeste paulista -, uma infraestrutura logística que favorece o abastecimento do mercado interno e externo, além de possuir uma das maiores regiões produtoras de tilápia do Brasil, a de Santa Fé do Sul.

Dentre as informações que se pretende obter estão: identificar e descrever os tipos de produtos oferecidos, as quantidades comercializadas, os preços, seu comportamento e os fatores que os influenciam, além das possibilidades de melhorias no processo de comercialização.

No que se refere à oferta, outros países que se destacam na produção de pescado estudaram previamente seus mercados e realizaram seu planejamento estratégico. Com isso, alavancaram a produção de determinadas espécies, focando em produtos e mercados específicos. Atualmente eles se beneficiam do crescimento no consumo mundial, como é o caso do salmão.

Pelo lado da demanda, não apenas a quantidade consumida deve ser considerada, mas também os gostos, as preferências, os preços e as quantidades de consumidores atuais e potenciais. Essas questões serão levantadas e discutidas no presente trabalho. No Brasil ainda há um mercado inexplorado devido ao baixo consumo de proteína oriunda da pesca e aquicultura. Somado a isso, há uma demanda crescente dos restaurantes (food service) e do mercado internacional, principalmente nos 
Estados Unidos e Europa. Para atender esses mercados é preciso conhecer a concorrência, os tipos e a qualidade de produto que satisfazem esse público-alvo.

Este trabalho foi organizado de forma a fornecer uma revisão de literatura sobre a aquicultura, a tilapicultura no Brasil e no estado de São Paulo, o mercado de pescado e a teoria econômica da oferta e demanda. Em materiais e métodos apresenta-se a forma como os dados serão obtidos e como serão feitas as análises para cada determinante de oferta e demanda a ser estudado. Na seção de resultados são apresentados os dados e as análises referentes ao mercado de tilápia, tais como volumes comercializados, os preços praticados, os agentes de comercialização, quantidade consumida, dentre outros.

\section{Objetivos}

O objetivo desta pesquisa é desenvolver um estudo exploratório sobre o mercado da tilápia no Estado de São Paulo. Para tanto, definem-se como objetivos específicos:

2.1 Identificar e descrever os tipos de produtos oferecidos neste mercado;

2.2 Estimar as quantidades de produto comercializadas e consumidas no estado;

2.3 Identificar os preços dos produtos, seu comportamento e os fatores que os influenciam; e

2.4 Identificar possibilidades de melhorias no processo de comercialização.

\section{Revisão de Literatura}

3.1 Panorama da Aquicultura

\subsubsection{Produção mundial de pescado}

A produção mundial de pescado oriunda tanto da pesca quanto da aquicultura em 2013 foi de, aproximadamente, 160 milhões de toneladas, segundo dados da FAO (Food and Agricultural Organization - Organização da Alimentação e Agricultura). 0 
maior produtor mundial de pescado é a China, que em 2010, produziu $37,69 \%$ da produção mundial (63,5 milhões de toneladas). O Brasil naquele mesmo ano produziu 1,2 milhões de toneladas de pescado, o equivalente a $0,75 \%$ da produção mundial, assumindo a 19 a posição no ranking dos maiores países produtores. Na figura abaixo é possível ver a produção brasileira de pescado em comparação com os maiores produtores mundiais:

Tabela 1 - Ranking mundial de produção de pescado em toneladas.

\section{Produção Total de Pescado \\ Ranking mundial em toneladas (2010)}

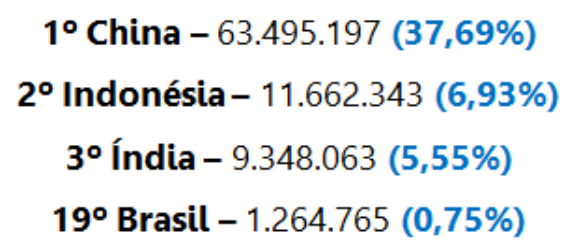

Fonte: 1ํAnuário Brasileiro da Pesca e Aquicultura do MPA, 2014

Quando comparado aos países da América do Sul, o Brasil assume o terceiro lugar, ficando apenas atrás de Peru e Chile, que produziram, em 2010, 4,4 milhões de toneladas e 3,8 milhões de toneladas, respectivamente (BRASIL, 2011).

A aquicultura representa $41,2 \%$ do total do volume de pescado produzido no mundo e contribui com o crescimento do comércio internacional com espécies de alto valor como salmão, robalo, dourada, camarão e moluscos, mas também espécies de menor valor como tilápia, bagre, panga e carpa, negociadas tanto em nível nacional e nas grandes regiões produtoras, como também internacionalmente.

A taxa média anual de crescimento da aquicultura mundial entre 2000 e 2012 foi de $6,2 \%$, ou seja, a produção nesse período mais do que dobrou, passando de 32,4 milhões para 66,6 milhões de toneladas. Essa expansão se deu devido a novas áreas produtivas instaladas, novas espécies que estão sendo cultivadas, bem como intensificação da produção e diversificação da gama de produtos ofertados aos consumidores visando atender às suas necessidades (FAO, 2014). 
A estimativa da FAO é de que a produção aquícola mundial em 2030 atinja 186,3 milhões de toneladas, um aumento de $21 \%$ com relação à produção do ano de 2011 , sendo que a participação da aquicultura nesse volume poderá atingir $50 \%$ do total (FAO, 2013).

A produção mundial de tilápia é de, aproximadamente, 4,5 milhões de toneladas e, o valor total desta indústria é estimada em US\$ 6,7 bilhões. A tilápia foi a principal responsável pelas altas taxas de crescimento do setor de peixes brancos, havendo a produção se expandido para mais de 80 países e, os volumes crescidos a uma taxa média de $11 \%$ ao ano na última década. Atualmente a tilápia é a segunda espécie de peixe mais cultivada no mundo (HEINHUIS; NIKOLIK, 2015).

As previsões para 2030, segundo a $\mathrm{FAO}$, são de que o volume produzido de tilápia quase dobre, atingindo 7,3 milhões de toneladas. A participação da tilápia dentre as espécies produzidas na aquicultura tende a atingir $7 \%$ nos próximos 15 anos, um dos maiores crescimentos previstos pela instituição (FAO, 2013).

A China é o maior produtor mundial de tilápia e, os Estados Unidos, o maior importador (mais de 228 mil toneladas por ano). A América Latina, contudo, possui vantagens frente ao maior produtor devido à sua localização, acesso aos ingredientes para a ração e recursos naturais. Apesar de em 2012 a região ter produzido 453 mil toneladas de tilápia, o que representa aproximadamente $10 \%$ da produção mundial da espécie, há previsões de que esse volume atinja 2 milhões de toneladas até 2025 sendo, mais da metade desse volume ofertado pelo Brasil (HEINHUIS; NIKOLIK, 2015).

Em anos recentes, a exportação de tilápia da América Latina para os Estados Unidos tem crescido. O produto mais exportado por esta região ao mercado americano é o filé de tilápia fresco. Para expandir essa indústria será preciso desenvolver as indústrias processadoras, de ração e logística (HEINHUIS; NIKOLIK, 2015).

\subsubsection{Produção brasileira de pescado}

A produção brasileira de pescado em 2011 foi de 1,4 milhões de toneladas, 13,2\% maior em relação a 2010. A pesca extrativa marinha é a principal fonte de produção do pescado nacional, conforme apresentado na figura 1 abaixo: 
Figura 1 - Porcentagem de participação dos diferentes sistemas de produção de pescado no Brasil

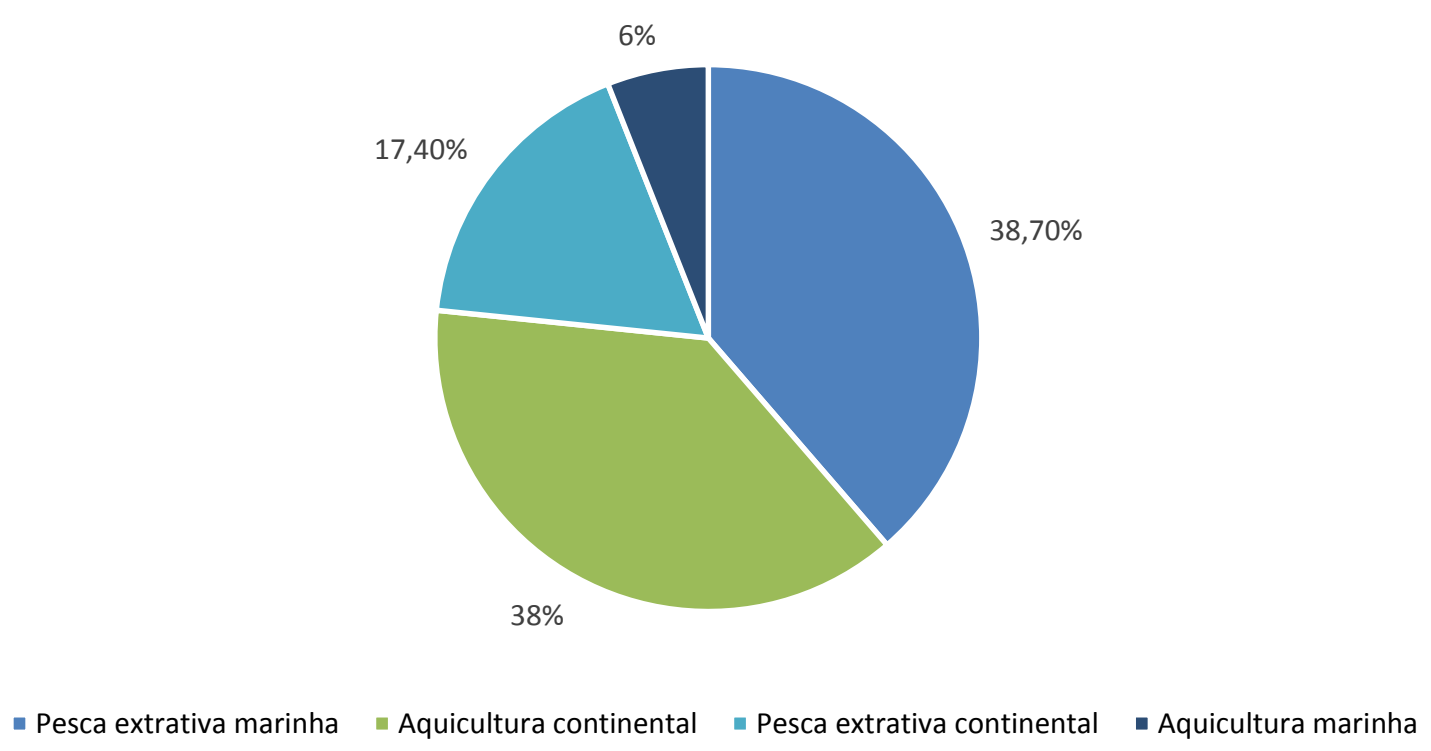

Fonte: Boletim estatístico da pesca e aquicultura do MPA, 2011

Apesar da pesca extrativa marinha representar a maior contribuição ao volume de pescado produzido nacionalmente, a participação da aquicultura continental vem aumentando e, assim como já acontece em outros países, o volume de pescado provenientes da aquicultura poderá ultrapassar o da pesca. A figura abaixo mostra a participação do volume de pescado provenientes de pesca e aquicultura nos maiores países produtores em comparação com o Brasil:

Figura 2 - Ranking mundial de produção de pescado de pesca extrativa e aquicultura, em toneladas.

AQUICULTURA

Ranking mundial em toneladas (2010)

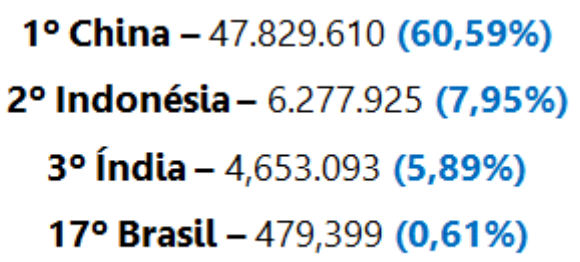

\section{PESCA EXTRATIVA}

Ranking mundial em toneladas (2010)

$$
\begin{gathered}
\mathbf{1}^{\circ} \text { China - } 15.665 .587(17,50 \%) \\
2^{\circ} \text { Indonésia - } 5.384 .418(6,02 \%) \\
3^{\circ} \text { Índia - } 4.694 .970(5,25 \%) \\
\mathbf{2 5}^{\circ} \text { Brasil - } 785.366(0,88 \%)
\end{gathered}
$$


O Brasil tem características que favorecem a sua produção aquícola tanto continental quanto marinha. Além de sua extensão litorânea, o país conta com aproximadamente $12 \%$ da água doce disponível no planeta, cerca de 5 milhões de hectares de reservatórios naturais e artificiais e clima favorável para o crescimento de várias espécies (COSTA NOGUEIRA, 2008).

Apesar de todas essas vantagens, algumas desvantagens podem ser apontadas como entraves para o desenvolvimento deste mercado competitivo no Brasil, como falta de comunicação entre os elos da cadeia, mercado fragmentado, falta de dados estatísticos, a existência de produtores informais e desorganização dos agentes do setor.

Segundo Pereira (2010), alguns dos entraves para o desenvolvimento do setor são a baixa qualidade higiênico-sanitária dos produtos comercializados, o baixo consumo de pescado no Brasil e escassez de informações setoriais publicadas. Além destes, períodos de estiagem prolongadas, como a ocorrida em 2014, podem afetar a produção de peixes.

A análise da produção nacional de pescado por Unidade da Federação para o ano de 2011 demonstrou que o Estado de Santa Catarina se manteve como o maior produtor de pescado do Brasil, com 194.866,6 t (13,6\%), seguido pelos estados do Pará com 153.332,3 t (10,7\%) e Maranhão com 102.868,2 t (7,2\%). Os estados da Bahia, Rio Grande do Sul, São Paulo, Mato Grosso, Alagoas, Sergipe e Distrito Federal apresentaram uma redução em relação ao volume produzido em 2010. No entanto, para os demais estados foi observado um incremento na produção de pescado em relação ao ano de 2010 (MPA, 2011). 
Tabela 2. Produção aquícola continental 2011 - por Regiões e Unidades da Federação

\begin{tabular}{|c|c|c|c|}
\hline Posição & Estado & $\begin{array}{c}\text { Produção } \\
(\mathbf{t})\end{array}$ & $\%$ \\
\hline 1 & Paraná & 73.831 & $14 \%$ \\
\hline 2 & Santa Catarina & 53.642 & $10 \%$ \\
\hline 3 & Mato Grosso & 48.748 & $9 \%$ \\
\hline 4 & São Paulo & 43.491 & $8 \%$ \\
\hline 5 & Ceará & 36.066 & $7 \%$ \\
\hline 6 & Maranhão & 32.238 & $6 \%$ \\
\hline 7 & Amazonas & 27.604 & $5 \%$ \\
\hline 8 & Rio Grande do Sul & 26.202 & $5 \%$ \\
\hline 9 & Minas Gerais & 25.918 & $5 \%$ \\
\hline 10 & Roraima & 25.163 & $5 \%$ \\
\hline 11 & Bahia & 20.704 & $4 \%$ \\
\hline 12 & Piauí & 17.001 & $3 \%$ \\
\hline 13 & Goiás & 13.647 & $3 \%$ \\
\hline 14 & Mato Grosso do Sul & 12.454 & $2 \%$ \\
\hline 15 & Tocantins & 12.412 & $2 \%$ \\
\hline 16 & Outros & 75.369 & $14 \%$ \\
\hline & BRASIL & 544.490 & $100 \%$ \\
\hline
\end{tabular}

Fonte: Boletim Estatístico da Pesca e Aquicultura 2011.

Analisando a produção da aquicultura continental por estado brasileiro (tabela 2), em 2011 o Paraná liderou o ranking com 14\% da produção nacional, conforme tabela acima. O Paraná foi o primeiro estado brasileiro a organizar de forma racional a atividade, inclusive com a implantação de frigoríficos especializados em beneficiamento de tilápia, com destaque para os municípios de Toledo e Assis Chateaubriand (FIGUEIREDO JÚNIOR E VALENTE JÚNIOR, 2008)

\subsubsection{Tilapicultura no Brasil e no Estado de São Paulo}

O cultivo da tilápia desenvolveu-se de forma significativa no Brasil a partir de 1996, sendo que em 2002 já era a espécie de peixe mais cultivada no país (COSTA NOGUEIRA, 2008). Desde então a produção nacional continuou crescendo e, em 
2011, a tilápia já representava $47 \%$ da produção de peixes produzidos pela piscicultura brasileira.

Segundo dados da FAO (2014), a tilápia, incluindo a tilápia do Nilo, é a espécie mais cultivada na aquicultura mundialmente e o mesmo pode-se dizer do Brasil, que produz a espécie em quase todos os estados do país, ficando de fora apenas o estado do Amazonas.

Analisando a produção aquícola brasileira discriminada por espécie, é possível verificar que a tilápia é a espécie mais cultivada, seguida do tambaqui, tambacu e carpa.

Tabela 3. Produção nacional de pescado (t) da aquicultura continental por espécie.

\begin{tabular}{|l|r|r|}
\hline \multicolumn{1}{|c|}{ Espécie } & Produção 2011 & \multicolumn{1}{|c|}{$\%$} \\
\hline Tilápia & $253.824,1$ & $47 \%$ \\
\hline Tambaqui & $111.084,1$ & $20 \%$ \\
\hline Tambacu & $49.818,0$ & $9 \%$ \\
\hline Carpa & $38.079,1$ & $7 \%$ \\
\hline Pacu & $21.689,3$ & $4 \%$ \\
\hline Tambatinga & $14.326,4$ & $3 \%$ \\
\hline Pirapitinga & $9.858,7$ & $2 \%$ \\
\hline Pintado & $8.824,3$ & $2 \%$ \\
\hline Curimatã & $7.143,1$ & $1 \%$ \\
\hline Bagre & $7.048,1$ & $1 \%$ \\
\hline Matrinxã & $5.702,1$ & $1 \%$ \\
\hline Outros & $5.372,2$ & $1 \%$ \\
\hline Paiu & $4.309,3$ & $1 \%$ \\
\hline Truta & $3.277,2$ & $1 \%$ \\
\hline Jundiá & $1.747,3$ & $0 \%$ \\
\hline Pirarucu & $1.137,1$ & $0 \%$ \\
\hline Traíra & 926,5 & $0 \%$ \\
\hline Piraputanga & 265,0 & $0 \%$ \\
\hline Cascudo & 58,0 & $0 \%$ \\
\hline Total & $\mathbf{5 4 4 . 4 9 0 , 0}$ & $100 \%$ \\
\hline
\end{tabular}

Fonte: Boletim Estatístico da Pesca e Aquicultura 2011

Em 2011 a produção brasileira de tilápia ultrapassou 253 mil toneladas, de acordo com o Ministério da Pesca e Aquicultura (MPA). Isso representou um crescimento de $64 \%$ se comparado ao ano 2010 , quando o volume produzido foi de 155 mil toneladas. 
Figura 3 - Produção Nacional de Tilápia de 2008 a 2011 em toneladas.

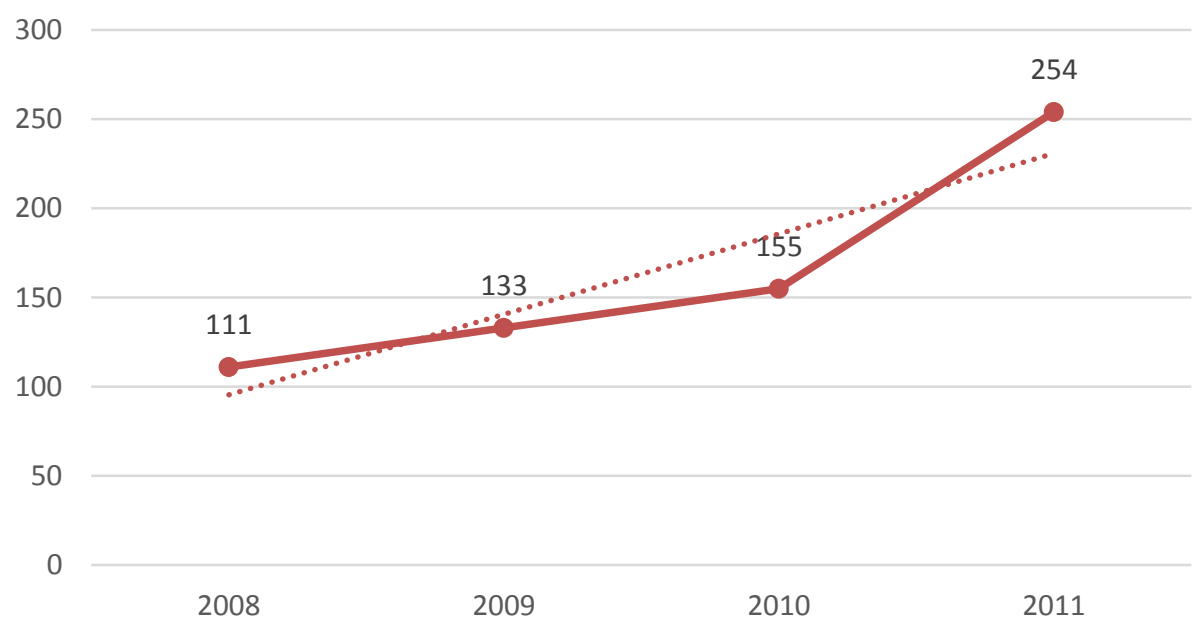

Fonte: Boletim Estatístico da Pesca e Aquicultura, 2011

Essa taxa elevada de crescimento da produção da tilápia no Brasil ocorre devido a fatores favoráveis de produção e consumo. Dentre os fatores de produção é possível destacar algumas de suas características que favorecem a aquicultura: crescimento rápido, fácil reprodução, adaptabilidade a uma variedade de condições ambientais e a alimentos artificiais (rações) (DUAN et al., 2011). Na parte do consumo, a tilápia é um peixe de carne branca, de textura firme, sabor suave, não tem espinhas em " $Y$ " e por isso é bem aceita pelos consumidores (JORY et al., 2000)

Silva (2007) cita que,

O Brasil tem o potencial de ser o maior produtor de tilápia do mundo. É possível produzir tilápia em qualquer parte do território brasileiro. A tilápia, que era um peixe praticamente desconhecido há alguns anos, é hoje uma estrela no mercado americano. É atualmente o sexto pescado mais consumido nos EUA. No Estado do Paraná está concentrado um enorme número de piscicultores e a introdução e difusão da linhagem permitirá melhor rentabilidade para o setor produtivo. Atinge o peso comercial mais rapidamente (maior ganho de peso e crescimento, quantidade de filé), quando comparada com as linhagens de outros peixes convencionais. Possui maior resistência a doenças e variações climáticas, diminuindo assim o índice de mortalidade e consequentemente, maior produção (Silva, 2007. 11p).

Igarashi et al. (2009) afirmam que o interesse pelo cultivo da tilápia vem aumentando nos últimos anos devido à introdução da tecnologia de produção de machos, através 
principalmente da reversão sexual. Com o desenvolvimento destas tecnologias 0 peixe pode atingir entre $400 \mathrm{~g}$ e $500 \mathrm{~g}$ em 5 meses, sendo comercializado vivo ou abatido "in natura", inteiro, eviscerado, resfriado, filetado e congelado, como também para estocagem de pequenos açudes dos "pesque-pague", o que tem encorajado a expansão do seu cultivo, não somente extensivo, mas por outros sistemas, como o semi-intensivo em viveiros fertilizados com adubo orgânico, intensivo em "race-ways" e superintensivo, em tanques-rede flutuantes.

A tilapicultura nacional tem sido praticada majoritariamente por pequenos produtores, podendo ser encontrada em viveiros escavados ou em sistemas mais intensivos como o de tanque-rede. Viveiros escavados são mais comuns nos estados do Sul, onde se desenvolveu primeiro a produção industrial de tilápias. Já o sistema em tanque-rede (também conhecido como gaiola) é a modalidade em que o cultivo de tilápias vem se expandido tanto na região Sudeste quanto na região Nordeste, com empreendimentos instalados em açudes públicos e represas rurais (OSTRENSKY et al., 2007). O mapa abaixo, retirado de uma apresentação do ํㅡㄹ Congresso Mundial de Tilápia em 2013 mostra a distribuição regional da produção de tilápia.

Figura 4 - Distribuição regional da produção de Tilápia

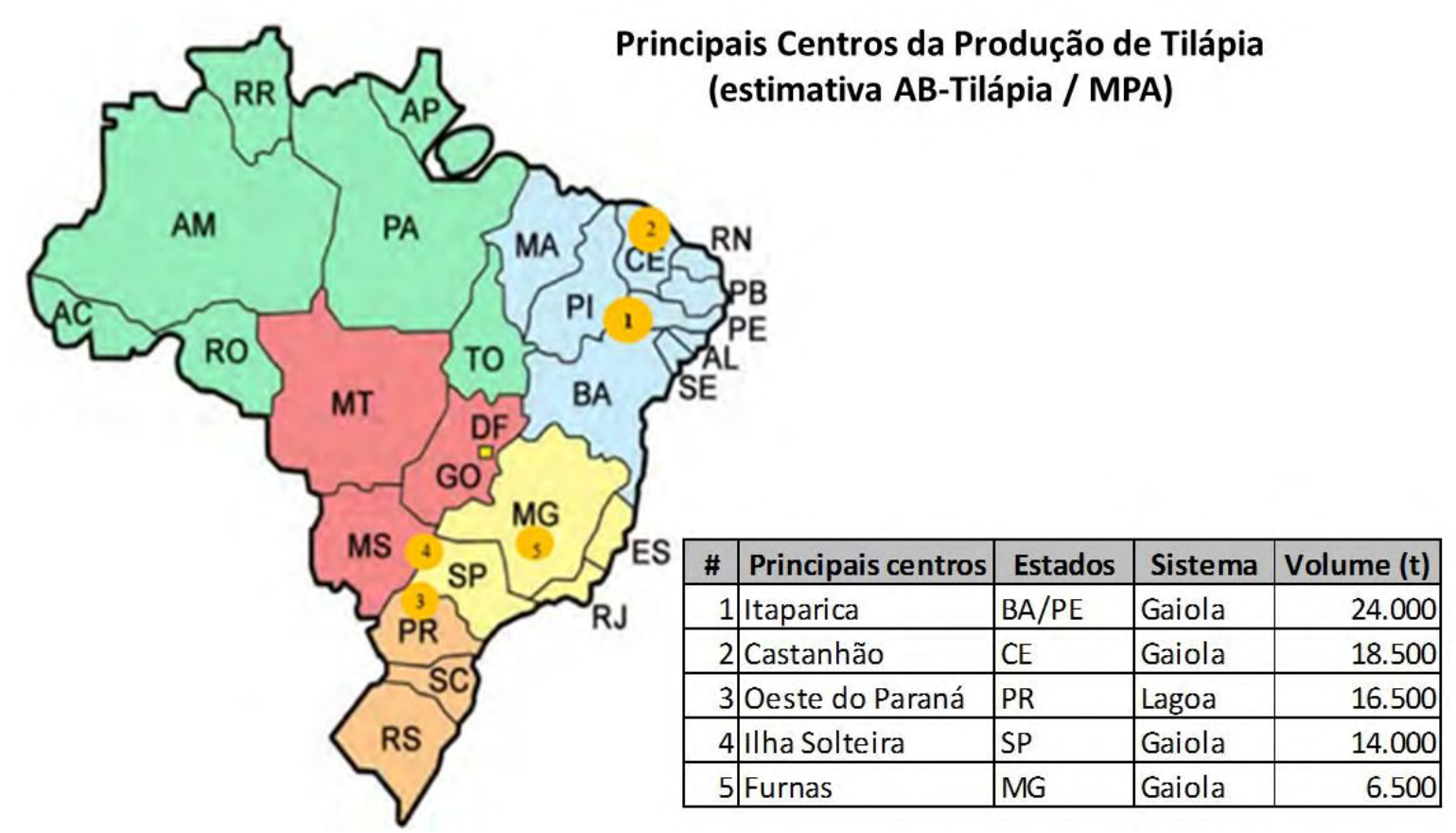

Fonte: Tendências e perspectivas do mercado e da produção de tilápia no Brasil. $2^{\circ}$ Congresso Mundial de Tilápia, 2013 
Nota-se que os sistemas produtivos para os principais centros apresentados estão em linha com as afirmações de Ostrensky et al. (2007)

De acordo com Sussel (2011a) a tilapicultura no estado de São Paulo é formada por pequenos e médios produtores, assim como em todo o território nacional. O volume produzido de tilápia no estado atende à demanda interna, e, portanto, não é comercializada em outro estado e nem exportado. Essas informações quanto às demandas serão atualizadas por meio dos levantamentos desta pesquisa e, também será medido o potencial para exportação de tilápia pelos produtores paulistas.

A produção no estado concentra-se no Noroeste, compreendendo a região de Santa Fé do Sul e reservatórios do Rio Paraná, do Rio Grande e do baixo Rio Tietê (SUSSEL, 2011a). Em 2014, uma seca ocasionou queda de 30\% na produção de Santa Fé do Sul, região responsável por uma produção anual de aproximadamente 22 mil toneladas de tilápia (GLOBEFISH, 2015b).

Por volta de $70 \%$ da tilápia produzida em São Paulo é processada em frigoríficos de peixe e comercializada na forma de filé nas grandes redes de supermercados. $\mathrm{O}$ restante é comercializado como peixe inteiro no Ceagesp ou como peixe vivo nos pesque-pague (turismo rural) (SUSSEL, 2011). Com relação a este dado, há algumas controvérsias em relação ao volume de tilápia processada (filetada), que esta pesquisa poderá ajudar a elucidar.

\subsection{Oferta e demanda por pescado}

O Brasil tem as condições necessárias para se tornar um dos principais fornecedores mundiais de peixes e frutos do mar, rivalizando com produtores como Índia, Noruega e até China, segundo um estudo do banco Rabobank publicado no início de 2013 (MELO; NIKOLIK, 2013). Entretanto, apesar de seus recursos naturais e a disponibilidade de grãos, a indústria do pescado no Brasil ainda tem que superar algumas barreiras para cumprir seu potencial. Dentre eles, pode-se destacar a burocracia necessária para obter permissões de explorar a água, a falta de padrões de biossegurança para produção, a indústria de ração para peixes ainda 
subdesenvolvida e a ausência de informações públicas sobre o setor (MELO; NIKOLIK, 2013).

Mas não só na parte produtiva estão os gargalos. A população brasileira se alimenta de pouca proteína de peixe quando comparada a outras nações. Segundo dados da FAO, em 2011 o consumo per capita de pescado no Brasil foi de 9,6 kg/habitante, enquanto que no Japão foi de $35,5 \mathrm{~kg} /$ habitante, China $31,6 \mathrm{~kg} /$ habitante e Noruega $47,6 \mathrm{~kg} /$ habitante.

Os períodos de maior comercialização de pescado no Brasil são dois, de acordo com Sonoda (2002): o primeiro é entre os meses de março e abril, causado pelo aumento na demanda associado à Semana Santa - em que a população de religião católica dá preferência ao consumo de carne de peixe em relação à carne vermelha. Essa afirmação é verdadeira também analisando os dados de venda mês a mês de peixes e frutos do mar de uma grade rede de supermercados do país (informação verbal) ${ }^{1}$.

Figura 5 - Vendas totais e de tilápia, mês a mês, de 2011 a2013, na peixaria de uma rede de supermercados

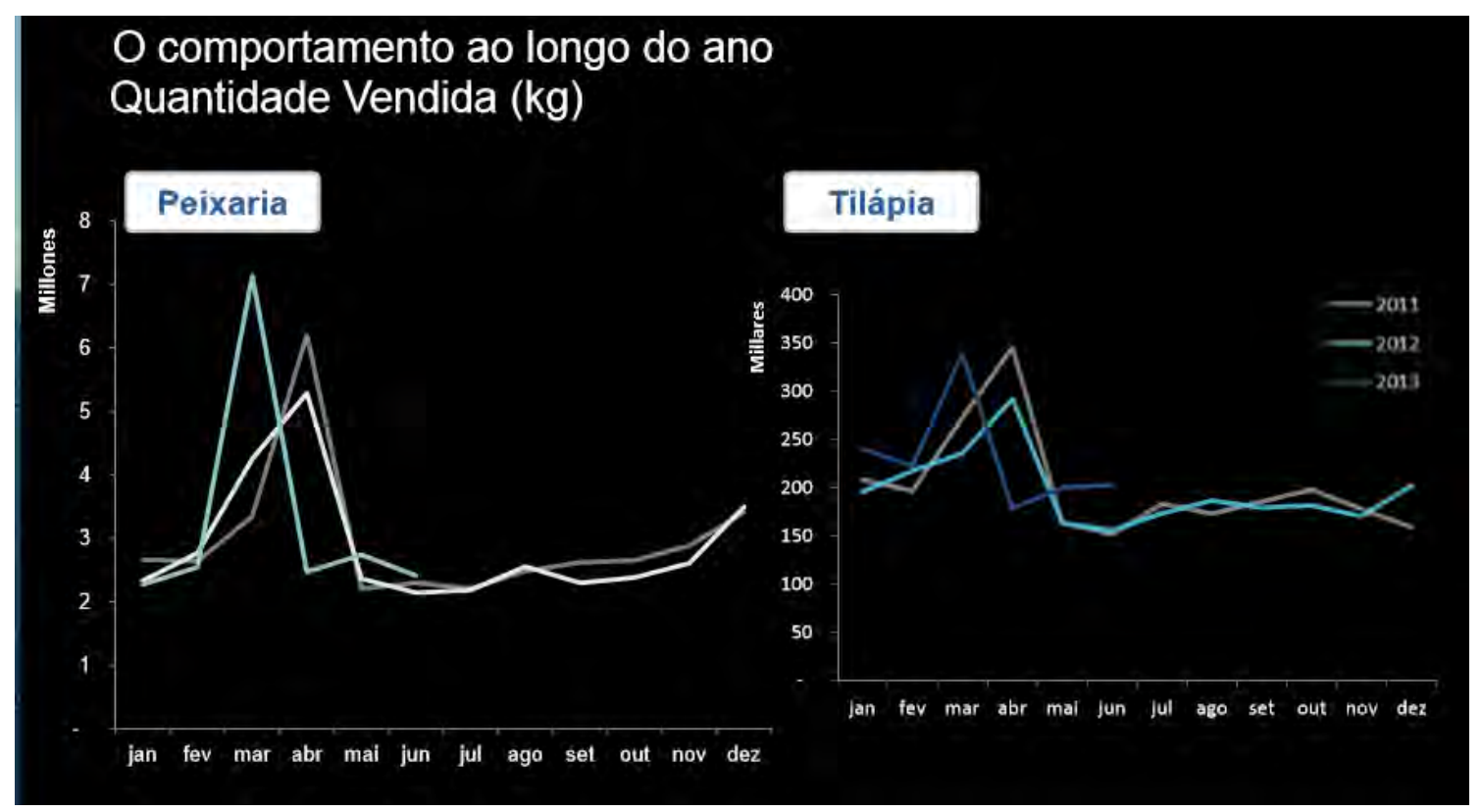

Fonte: $2^{\circ}$ Congresso Mundial de Tilápia.

\footnotetext{
${ }^{1}$ Informações apresentadas no 2을 Congresso Mundial de Tilápia, no Rio de Janeiro, por Meg Felippe, em 17 de setembro de 2013.
} 
O segundo período vai de agosto a outubro, período em que a pesca é mais favorável e há preferência por alimentação mais leve, devido às altas temperaturas. Nessa época, apesar do aumento da demanda, o crescimento da oferta faz com que os preços se mantenham relativamente baixos.

No inverno, ainda segundo Sonoda (2002), entre os meses de maio e julho, há uma redução da oferta de peixes e frutos do mar no mercado e, também, uma menor demanda por parte do consumidor que procura nesta época do ano alimentos mais energéticos. Por isso, nessa estação os preços são relativamente mais baixos em relação ao restante do ano.

Entre os meses de novembro e fevereiro o período é caracterizado como de baixa comercialização pois de um lado há redução da oferta - devido a uma redução na captura como resultado do defeso (proibição da pesca no período de desova) de diversas espécies - e, do outro lado, as festas de final de ano fazem com que haja aumento no consumo de outros tipos de carne, como as de suíno e aves, diminuindo a demanda por pescado (SONODA, 2002).

Os supermercados são importantes canais de vendas de pescado aos consumidores finais e nota-se que a preferência do brasileiro é para o peixe fresco, uma vez que este representa $56 \%$ das vendas de pescado deste supermercado em questão (informação verbal) ${ }^{1}$. Deste volume, a tilápia em 2013 representou 11\% do total. Os peixes frescos são vendidos no varejo inteiros, em filé ou postas. Já os congelados são vendidos em filés e, a participação nas vendas representou $29 \%$ naquele ano, sendo a tilápia responsável por $2 \%$ desse total. Outro dado interessante é que a tilápia, para esta rede, está entre as 20 espécies mais vendidas e, apenas estas representam $70 \%$ do faturamento da peixaria (informação verbal) ${ }^{1}$.

\subsubsection{Preços}

Tanto peixes quanto frutos do mar são proteínas que têm potencial para terem aumentada, de forma significativa, a sua oferta no mercado devido ao crescimento da produção via aquicultura. O resultado dessa transição de pesca para aquicultura como modelo de suprimento de pescado no mercado tem chances de reduzir os preços para algumas espécies e, tilápia é uma delas. 
Porém, é preciso que a cadeia e o mercado estejam organizados para que então sejam possíveis os ganhos com a produção em escala. No Estados Unidos por exemplo, o consumo de salmão de 1990 a 2007 mais do que dobrou devido ao aumento eficiente da produção desta espécie e maior disponibilidade no mercado americano via importação, o que causou declínio no preço na ordem de $50 \%$ (KNAPP et al., 2007; ASCHE, 2008; VALDERRAMA; ANDERSON, 2010 apud KITE-POWELL et al., 2013) ${ }^{2}$.

Um aumento na oferta possibilita expansão do mercado e pode diminuir o preço ao consumidor final. Dentre os benefícios para o consumidor, preços mais baixos de pescado beneficiam o acesso a uma alternativa de proteína saudável (KITE-POWELL et al., 2013). Um dos fatores que pode influenciar na queda do preço da tilápia é o custo de produção e, este só irá diminuir significativamente quando a cadeia receber a atenção devida da área de pesquisa e investimentos da indústria em sistemas de produção de larga escala (KITE-POWELL et al., 2013).

No caso da indústria do salmão, Asche et al. (2013) afirma que apesar de ainda não existirem dados suficientes para concluir se as fazendas produtoras devem ou não ter um tamanho maior para promover o crescimento da produtividade, considerando-se que as empresas para esta espécie se tornaram mais concentradas em todos os países com larga produção, sugere-se que existam benefícios da produção em escala em outras partes da cadeia produtiva. Segundo o autor, parece ser vantajoso ser uma empresa grande em negociações de compras de serviços, na produção e/ou em marketing e vendas, e que a existência de grandes empresas tem ajudado a indústria de salmão na tentativa de crescer.

O preço médio do filé de tilápia fresco em 2012 comercializado na rede GPA de supermercados foi de $\mathrm{R} \$ 17,58 / \mathrm{kg}$. Esse valor foi apontado como o segundo mais elevado de suas lojas com peixaria, ficando abaixo apenas do preço do salmão (peixe importado do Chile). Já a tilápia vendida inteira teve um preço médio de venda de $\mathrm{R} \$$

\footnotetext{
${ }^{2}$ Knapp, G., C.A. Roheim, \& J.L. Anderson (2007) The Great Salmon Run: Competition Between Wild and Farmed Salmon. TRAFFIC North America World Wildlife Fund, Washington, DC, apud
} 
$4,78 / \mathrm{kg}$ e, o filé de tilápia congelado $R \$ 16,86$ conforme apresentado no $2^{\circ}$ Congresso Mundial de Tilápia (2013).

Havendo diminuição no preço na gôndola dos supermercados pode-se esperar que o consumo da tilápia torne-se uma prática mais comum das dietas dos brasileiros assim como aconteceu com o salmão, que desde o início da sua criação de forma intensiva tornou-se uma fonte de proteína mais acessível nos países produtores, responsável pela transição de um alimento de luxo para um produto de consumo no dia-a-dia nesses locais (OGLEND, 2013). Isso pode ser conseguido por meio da redução do custo de produção e processamento.

A redução no preço da tilápia pode se dar também pelo aproveitamento econômico de todas as partes do peixe. O rendimento médio da tilápia para a produção de filé é $33 \%$ (COSTA NOGUEIRA, 2008) e, como hoje os produtos derivados dessa espécie não são ofertados no mercado (como couro, produtos processados, carne mecanicamente separada, silagem, dentre outros), ou seja, são descartados, o produtor tem que pagar os custos de produção e ainda receber o seu preço apenas sobre o filé, o que pode ser uma das razões para a manutenção de valor elevado do produto nas gôndolas dos supermercados e peixarias.

As empresas brasileiras do setor avícola têm um modelo interessante nesse aspecto. O setor buscou desenvolver e fornecer produtos que estivessem bem em linha com as preferências do consumidor em termos de coloração da carne, cortes e peso das embalagens e, a evolução tecnológica possibilitou o uso das partes menos nobres do frango, como partes de osso, costelas e pescoço em alimentos processados (PIEDADE; SILVA, 2002), o que ajuda na lucratividade produtor, tirando assim a pressão dos cortes nobres, sendo estes ofertados a preços mais acessíveis ao mercado.

\subsubsection{Tecnologia e aproveitamento de resíduos}

As possibilidades para os subprodutos do pescado - cabeça, pele, escama, vísceras, carcaça - são diversas e, diferentemente de outros resíduos, têm um apelo nutricional (FERRAZ DE ARRUDA, 2012). Os coprodutos gerados a partir dos resíduos, em 
geral, podem ser destinados a alimentação humana ou à produção animal - na forma de ração - e vegetal, como fertilizante (EMBRAPA, 2013).

A silagem, obtida na forma química, enzimática ou microbiológica é um produto liquefeito utilizado como ingrediente para ração ou adubo (OETTERER, 2012). A compostagem dos resíduos de pescado gera um composto orgânico que pode ser utilizado na alimentação animal ou como fertilizante. Outros coprodutos que podem ser gerados são a farinha e o óleo de peixe, ricos em ômega-3, destinados para a produção de ração e, atualmente, são essas as indústrias que absorvem a maior parte do volume do resíduo de pescado (OETTERER, 2006).

O minced, ou polpa - parte comestível do pescado, separada mecanicamente - é outra opção de aproveitamento de resíduos do pescado. Essa carne mecanicamente separada (CMS) - torna-se um ingrediente que é utilizado no desenvolvimento de novos produtos à base de peixe, como empanados e hambúrgueres, que têm alto rendimento e reduz a quantidade de material descartado (ANGELINI, 2012). Gelatina é uma outra opção de coproduto que pode ser gerado a partir de partes não comestíveis do pescado (OETTERER, 2006).

Para a pele de peixe - que representa entre $4,5 \%$ e $8,5 \%$ do peso - ao invés de descarta-la é possível transformá-la em couro por meio de curtimento. Esse tipo de atividade ainda é desenvolvido mais artesanalmente, em algumas comunidades próximas a colônias de pescadores, envolvendo a população local que usa a atividade como uma forma de melhoria da condição de vida, educação ambiental e uma renda adicional. $O$ couro do peixe pode ser trabalhado e transformado em roupas, sapatos, bolsas e bijuterias (VIDOTI, 2011).

Além das alternativas apresentadas acima, o biocombustível a partir das vísceras do pescado se mostrou também uma alternativa técnica e economicamente viável. Contudo, para funcionar, é preciso uma logística estruturada na região em que a máquina estiver instalada para a coleta do material a ser utilizado para a produção do biocombustível - pois também demanda certo controle de qualidade da matéria-prima que será processada (MELO, 2010)

A graxaria é a alternativa mais simples, de baixo investimento e a mais praticada atualmente pelos produtores paulistas. Da graxaria saem farinha e óleo de peixe 
destinados à produção de ração para peixe. Uma vez que os subprodutos da indústria do pescado têm o diferencial do alto valor nutricional, planejar a destinação dos resíduos da indústria pode aumentar a lucratividade do produtor e diminuir a dependência sobre o filé, reduzindo consequentemente o preço para o consumidor.

\subsubsection{Consumo}

A crescente demanda por consumo de peixe, embora haja variações consideráveis entre países e regiões em termos do montante total de pescado para consumo humano, reflete grandes diferenças nos hábitos alimentares, disponibilidade deste e outros alimentos, além dos preços e níveis socioeconômicos (FABINYI, 2012; OKEN et al., 2012). Peixes e frutos do mar representam uma importante fonte de micronutrientes essenciais e proteína animal para grande parte da população mundial. Globalmente, os peixes fornecem a cerca de três bilhões de pessoas, aproximadamente $20 \%$ de sua ingestão diária de proteína animal (FAO 2012 apud VILASANTE et al., 2013).

Um dos principais constrangimentos que afetava a indústria de tilápia era o problema de off-flavour (sabor residual de barro). A indústria tem feito um esforço para treinar os produtores e seus funcionários para reconhecer a presença de as algas e os odores que caracterizam o mau sabor. Para resolver essa questão, muitas fazendas e processadores desenvolveram sistemas e procedimentos de depuração para garantir que nenhum peixe com sabor fora do padrão aceitável pelo consumidor seja processado. Além disso, testes e ensaios laboratoriais mais sofisticados também estão disponíveis para ajudar os produtores e processadores na identificação de offflavour, evitando que este produto chegue até o consumidor (FITZSMMONS et al., 2011)

Costa Nogueira (2008) também afirma que o desenvolvimento tecnológico nas técnicas de cultivo e de processamento de tilápias tem melhorado a qualidade do peixe e, consequentemente, a sua imagem perante os consumidores, passando da condição de peixe pequeno, cheio de espinhas, com gosto de barro e que é encontrado em qualquer lagoa, para "alimento saudável e de alta qualidade". 
Apesar disso, Zimmermann (2010) defende que o consumo de tilápia só irá aumentar significativamente nos países da América Latina quando houver declínio no preço no mercado local.

Nos Estados Unidos a demanda por tilápia cresceu de forma rápida na última década devido às características que agradam os americanos: carne branca, sem odor forte, fácil de filetar e sabor suave (VANNUCCINI, 2001). Segundo Heinhuis e Nikolik (2015), os americanos consomem mais tilápia do que países conhecidos como grandes consumidores desta espécie como Egito e China.

Os principais fornecedores de tilápia congelada e fresca para os Estados Unidos são países da Ásia e da América Central. O consumo de peixe de carne branca (bacalhau, tilápia, panga) pelos americanos superou o de camarão em 6,2\% em 2012 $(F A O, 2014)$. Juntamente com o panga, a tilápia tem a principal influência nesse crescimento e, nos próximos anos, a demanda por peixes de carne branca vai continuar a crescer devido o maior foco em dietas mais saudáveis (HEINHUIS; NIKOLIK, 2015).

A FAO (2014) também aponta outros países que têm a tilápia como uma das espécies de peixe mais consumida por seus habitantes, como Bangladesh, Indonésia, Filipinas, Sri Lanka e Tailândia. Além desta informação, a instituição indica que uma grande parte da tilápia cultivada mundialmente é comercializada na forma de filé.

Segundo Turra et al. (2009), uma das vantagens competitivas do pescado, frente a outras carnes, é apresentar uma diversidade de produtos e espécies que atendam nichos diferenciados de mercados consumidores, com uma grande faixa de elasticidade-renda. Porém, é opinião de vários autores como Heinhuis e Nikolik (2015), Duan et al. (2011) e Costa Nogueira (2008), que a reunião dos atributos pela tilápia com tamanha eficiência, resulta na escolha desta espécie como a que terá a importância no mercado nacional e mundial similar à da carne de aves. Essa expectativa é alinhada com as previsões da FAO para 2030 que indicam um 
crescimento no volume produzido de tilápia de $30 \%$, enquanto que para outras espécies como camarão e salmão, apenas 10\% (FAO, 2014).

No Brasil, a participação das vendas de tilápia ao consumidor final, segundo dados de uma rede varejista foi, em 2013: $24 \%$ no Ceará, $15 \%$ no Piauí, $11 \%$ na Paraíba e Distrito Federal, 9\% em São Paulo, 8\% no Rio Grande do Norte, Pernambuco e Alagoas, 7\% em Minas Gerais e Goiás e 5\% no Mato Grosso do Sul (informação verbal) ${ }^{1}$. Nota-se que São Paulo é um dos principais mercados consumidores, apesar de ainda abaixo de estados do Nordeste; apesar disso, mostrou-se como o estado da região Sudeste com maior expressividade no consumo de tal espécie. Além da qualidade, a aceitação pelo consumidor também é motivada pela oferta regular do produto, o que gera confiança e fidelidade do cliente (informação verbal) ${ }^{1}$.

\subsection{Mercado e Teoria Econômica}

\subsubsection{Oferta e Demanda}

O mercado e a demanda por peixes têm sido exemplos e objetos de estudo de economistas há alguns anos (GRADDY, 2006). Alfred Marshall usou o peixe fresco para uma série de exemplos em seu livro "Princípios de Economia". Bell (1968) examinou o efeito sobre o preço do peixe do decreto papal de 1966 em que os católicos não precisavam mais se abster de carne às sextas-feiras, exceto durante a Quaresma, concluindo que essa mudança no decreto teve uma influência negativa sobre os preços do pescado e, portanto, as receitas do setor.

Segundo Asche e Bjorndal (2011), mercado pode ser definido pelos seus canais de distribuição, seus produtos e preços. Definições mais simples são frequentemente baseadas na relação entre os preços. Passos e Nogami (2005) afirmam que os mercados estão no centro da atividade econômica e, é por essa razão, que muitos temas importantes em economia estão relacionados à maneira de funcionar desses mercados.

De acordo com os conceitos econômicos, um mercado se trata de um grupo de compradores e vendedores de um determinado bem ou serviço (MANKIW, 2010). Os 
compradores, como um grupo, determinam a demanda pelo produto e os vendedores, também como grupo, representam a oferta do produto (MANKIW, 2008).

Para fins de análise econômica, o conceito de mercado não implica, necessariamente, a existência de um lugar geográfico em que as transações se realizam. As mercadorias são vendidas segundo os mais diferentes contextos institucionais, tais como feiras, lojas, bolsas de valores etc., podendo o termo mercado aplicar-se a qualquer um deles. Basta apenas que compradores e vendedores de qualquer bem (ou serviço, ou recurso) interajam, resultando daí a possibilidade de comercializarem esse bem (PASSOS; NOGAMI, 2005).

Em um mercado de concorrência perfeita, por existirem diversos compradores e vendedores de um determinado produto, cada um deles tem um impacto insignificante sobre o preço geral do mercado, ou seja, os vendedores têm controle limitado sobre o preço que vendem seus bens uma vez que há outros vendedores oferecendo produtos muitos similares (MANKIW, 2010).

De acordo com Kupfer (2013), nesse âmbito da concorrência perfeita, o mercado é tratado como um espaço abstrato de encontro de oferta e demanda, adotando-se uma noção de produto como algo absolutamente bem definido e, portanto, perfeitamente distinguido na análise dos consumidores. Com relação a isso, o mercado reflete, em última instância, o conjunto de empresas produtoras desta mercadoria, de forma que a cada indústria corresponda a um mercado.

Ainda segundo Kupfer (2013), a suposição de um processo de crescimento da empresa marcado pela crescente diferenciação de produto, além de um movimento de expansão diversificante da atividade produtiva como uma estratégia fundamental, insere um alto teor de heterogeneidade de produto, ao menos no que se refere à percepção dos consumidores. Isto, portanto, implica maior importância analítica da substitutibilidade de produtos e do foco e direcionamento dos esforços competitivos, aspectos que passam a preponderar para uma definição mais adequada de mercado e indústria.

Assim, de maneira geral, mercado representa espaços de concorrência cuja delimitação não é (e não pode ser) estanque - nem no que se refere à definição do produto, nem quanto aos objetivos concorrenciais e de expansão. Do ponto de vista 
metodológico, a questão é definir o corte analítico - qual é efetivamente o grupo de produtos que compõe o mercado e, por conseguinte, que conjunto de empresas faz parte da análise de concorrência (KUPFER, 2013).

Oferta e demanda são as forças que fazem as economias de mercado funcionarem, que determinam a quantidade produzida e o preço pelo qual o bem será vendido (MANKIW, 2010). Este conceito é um tema básico da economia, já consolidado na literatura em livros-texto por diversos autores como Varian (2006), Nordhaus e Samuelson (2006), Mankiw (2010), dentre outros. Por tratar-se de uma adequada ferramenta de análise, outros estudos do mercado agropecuário que já utilizaram tais conceitos podem ser encontrados. Nos próximos parágrafos será apresentada uma revisão de literatura dessas contribuições, que servem de inspiração para a presente pesquisa.

Osaki (2003) analisou a oferta e demanda por cebola argentina. Como resultado, observou que há influência do preço da cebola nacional no valor pago pelo produto argentino, mostrando assim que o mercado argentino é altamente sensível às variações do produto no mercado brasileiro. $\mathrm{O}$ autor concluiu também que o Mercosul gerou efetiva integração desses mercados, afetando a produção e o consumo de cebolas em ambos os países.

Soares et al., (2009) analisou o mercado brasileiro de celulose. Como objetivo daquele trabalho, o autor especificou e estimou a oferta e demanda brasileira de celulose, bem como a oferta e a demanda de exportação, no período de 1969 a 2005. O método utilizado para análise dos resultados foi a regressão econométrica, estimada pela técnica dos Mínimos Quadrados de Dois Estágios (MQ2E), que indicaram que a oferta e a demanda interna de celulose, bem como a oferta e a demanda de exportação, são preço-inelásticas. Outras conclusões do estudo foram que a demanda interna era inelástica com relação à renda, ao contrário da demanda de exportação. A oferta interna era mais sensível a variações no preço das máquinas e equipamentos $\mathrm{e}$, a oferta de exportação, a variações na produção e no consumo interno. A demanda de exportação era sensível a variações na renda dos países importadores. 
O mercado de hortaliças foi estudado por Tofanelli et al. (2007). O questionário utilizado com parte da metodologia do trabalho continha questões sobre os volumes comercializados, fornecedores e preço médio de compra e venda. Com os dados levantados os autores identificaram os principais produtos comercializados no município de Mineiros (Goiás) (tomate, cebola, batata inglesa e melancia), os principais canais de comercialização (supermercados e quitandas) e as tendências dos preços.

No contexto do estudo de mercados, a teoria da demanda é definida como a quantidade de um bem ou serviço que o consumidor deseja adquirir em um determinado período de tempo. Esse desejo de adquirir é influenciado por alguns fatores e, além disso, derivado de hipóteses sobre a escolha do consumidor entre diversos bens que seu orçamento suporta adquirir. Assim, analisa-se o processo de escolha do consumidor frente a diferentes alternativas e, ao final, ele irá definir por aquela destinação que trará o maior nível de satisfação a ele (VASCONCELLOS; PINHO, 2002).

Os determinantes da demanda são definidos por diversos autores. Abaixo os fatores conforme estabelecidos por Rossetti (1997), Passos e Nogami (2005), Nordhaus; Samuelson (2006) e Mankiw (2010):

I) Preço do bem: A quantidade demanda de um bem é influenciada por seu preço. Normalmente é de se esperar que quanto maior for o preço de um bem, menor deverá ser a quantidade que o consumidor desejará adquirir desse bem.

II) Renda do consumidor: Para a maioria dos bens é de se esperar que uma elevação na renda do consumidor esteja associada a uma elevação nas quantidades compradas. Contudo, há outros em que a quantidade demandada varia inversamente em relação ao nível de renda do consumidor, que são os bens inferiores. Neste, se a renda aumenta, a quantidade procurada diminui; se a renda cai, a quantidade procurada aumenta.

III) Preço dos bens relacionados: A demanda de um produto pode ser afetada pela variação no preço de outros bens, que podem ser complementares ou substitutos. 
Bens complementares são aqueles que aumentam a satisfação do consumidor quando utilizados em conjunto. Nesse caso, a elevação no preço de um deles produz uma redução na demanda do outro. Os bens substitutos por sua vez são aqueles cujo consumo de um pode substituir o consumo de outro. Nesse caso haverá uma relação direta entre o preço de um bem e a demanda do outro bem.

IV) Gosto ou preferência do indivíduo: A demanda de um determinado bem (ou serviço) depende dos hábitos e preferências do consumidor. Estes, por sua vez, dependem de uma série de circunstâncias, tais como idade, sexo, tradições culturais, religião e até educação. Mudanças nesses hábitos e preferências podem provocar mudanças na demanda desse bem.

V) Expectativas: As expectativas das pessoas com relação ao futuro dos seus rendimentos e em relação ao comportamento dos preços também exercem papel fundamental na demanda por bens e serviços. Se as expectativas são de aumento nos rendimentos, elas poderão estar dispostas a gastar mais hoje, aumentando a demanda. Além disso, se as pessoas acharem que os preços irão aumentar no futuro, podem aumentar a demanda corrente de bens estocáveis.

VI) Número de consumidores: Mudanças significativas no número de consumidores potenciais é fator relevante para o posicionamento da procura de um grande número de produtos. Ele determina a magnitude da procura, embora esse fator deva ser complementado por outros.

Vasconcellos; Pinho (2002) e Ferguson (1999) não consideram como fatores que interferem na demanda o número de consumidores e as expectativas.

O comportamento da demanda de mercado pode ser determinado em função de quantidades e preços (VIAN, 2009); isso porque há uma relação explícita entre o preço de mercado de um produto e a quantidade demanda do mesmo, com os outros fatores mantidos constantes (NORDHAUS; SAMUELSON, 2006). Essa relação é chamada de função de demanda ou curva de demanda e pode ser representada em um gráfico, conforme abaixo: 
Figura 6 - Curva de Demanda

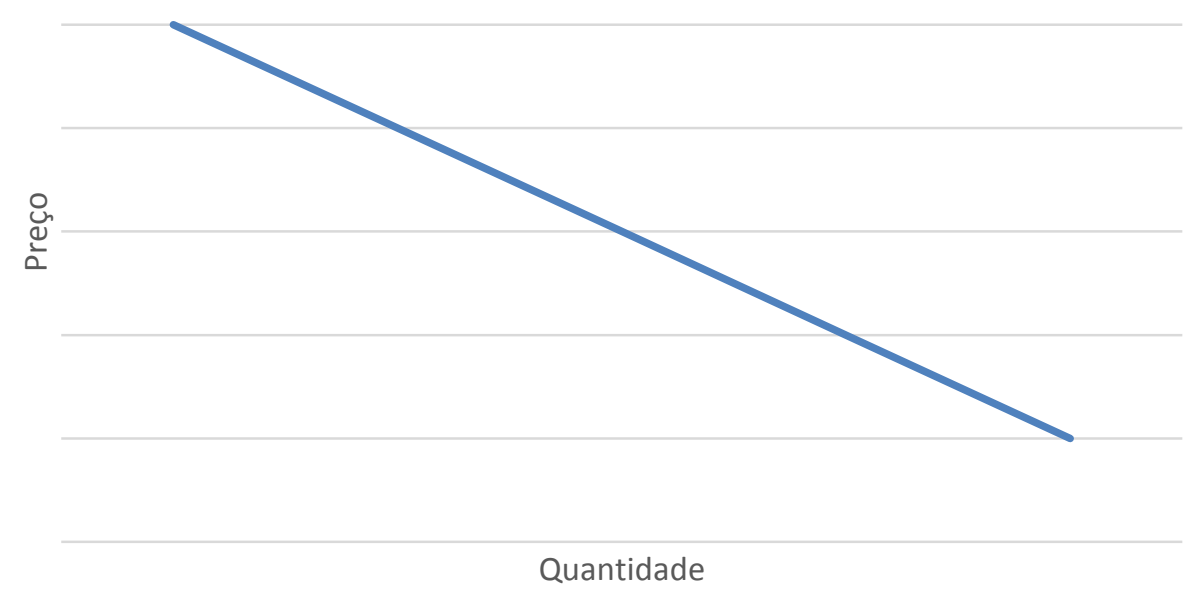

Fonte: NORDHAUS; SAMUELSON, 2006

Percebe-se que a curva de demanda é, em geral, negativamente inclinada. Isso é a manifestação do comportamento racional do consumidor - quanto maiores os preços, menores as quantidades adquiridas e, para preços menores, quantidades maiores são adquiridas (VASCONCELLOS; PINHO, 2002, NORDHAUS; SAMUELSON, 2006, VIAN, 2009).

Além das alterações de preços, um outro tipo de deslocamento pode ocorrer na demanda de mercado, originando assim movimentos que não são influenciados por preços. Isso significa que, se qualquer uma das variáveis acima mudar, à exceção do preço do produto, a curva da demanda será deslocada, aumentando (deslocamento da curva para cima) ou diminuindo (deslocamento da curva para baixo) a procura por um determinado bem (VASCONCELLOS; PINHO, 2002, NORDHAUS; SAMUELSON, 2006, VIAN, 2009).

A quantidade demandada pode cair ocasionada por alguns efeitos. Um deles pode ser o efeito substituição - quando o preço de um produto sobe, a pessoa o substitui por outros similares e, o outro, o efeito renda - quando o preço de um bem sobe, $o$ poder aquisitivo diminui, ou seja, diminui-se o consumo daquele e outros bens (VASCONCELLOS; PINHO, 2002, NORDHAUS; SAMUELSON, 2006). Já um 
aumento na intensidade do desejo para uma mercadoria provoca um acréscimo em sua demanda (Ferguson, 1999).

A teoria da oferta, por sua vez, a define como a quantidade de um bem ou serviço que os produtores desejam vender por unidade de tempo (VASCONCELLOS; PINHO, 2002, NORDHAUS; SAMUELSON, 2006, VIAN, 2009). A oferta de um determinado bem depende de seu preço - em todas as variáveis se mantendo constantes, quanto maior for o preço do bem, mais interessante é produzi-lo e, portanto, a oferta é maior (VASCONCELLOS; PINHO, 2002, VIAN, 2009).

Além disso, a oferta depende dos preços dos fatores de produção, ou seja, estes, juntamente com a tecnologia empregada, determinam o custo de produção e, quanto maior este, menor a lucratividade do produtor (VASCONCELLOS; PINHO, 2002, NORDHAUS; SAMUELSON, 2006). O emprego de tecnologia pode também vir a diminuir o custo de produção em alguns casos, otimizando o processo produtivo, tornando a oferta mais abundante, como por exemplo o que ocorreu com os fabricantes de automóveis (NORDHAUS; SAMUELSON, 2006).

Assim, tem-se como os determinantes da oferta, segundo Mankiw (2010):

I) Preço do bem: Normalmente espera-se uma relação direta entre a quantidade ofertada e o preço. Nessas condições, quanto maior for o preço de um bem (ou serviço), maior deverá ser sua quantidade ofertada no mercado. Da mesma forma, quanto menor for o preço de um bem (ou serviço), menor deverá ser sua quantidade ofertada no mercado.

II) Preço dos insumos: Reduções nos preços dos insumos diminuem os custos, tornando a produção mais lucrativa. $\mathrm{O}$ aumento na lucratividade estimula a firma a aumentar a produção e a oferta de seu produto no mercado. Inversamente, elevações nos preços dos fatores de produção acarretam aumentos de custos e diminuição na lucratividade, desestimulando a produção e diminuindo a oferta.

III) Tecnologia: Avanços tecnológicos que permitam obter um volume e produtividade maior de produção a custos menores aumentarão a lucratividade da empresa 
produtora do bem cujo processo foi beneficiado pela evolução tecnológica, estimulando a produção e aumentando a oferta do bem produzido por essa empresa.

IV) Expectativas: O produtor considera as alterações esperadas de preços, ou seja, se a expectativa é de aumento no preço do bem no futuro, é provável que ele retenha ou controle os volumes produzidos e ofertados, a fim de aproveitar preços mais altos posteriormente. Isso causa diminuição na oferta atual.

V) Número de produtores/vendedores: A oferta de mercado depende do número de vendedores. A decisão de um vendedor sair do mercado pode impactar significativamente a oferta dependendo sua participação no setor em que atua.

Alguns autores consideram alguns outros fatores como determinantes da oferta. Nordhaus e Samuelson (2006) também consideram tecnologia e preço dos insumos, assim como Mankiw (2010), porém, adicionam preço de produtos relacionados, políticas governamentais e influências especiais. Passos e Nogami (2005) incluem a estes as condições climáticas, e Rossetti (1997) acrescenta capacidade instalada e condições de oferta dos fatores.

Figura 7 - Curva de Oferta

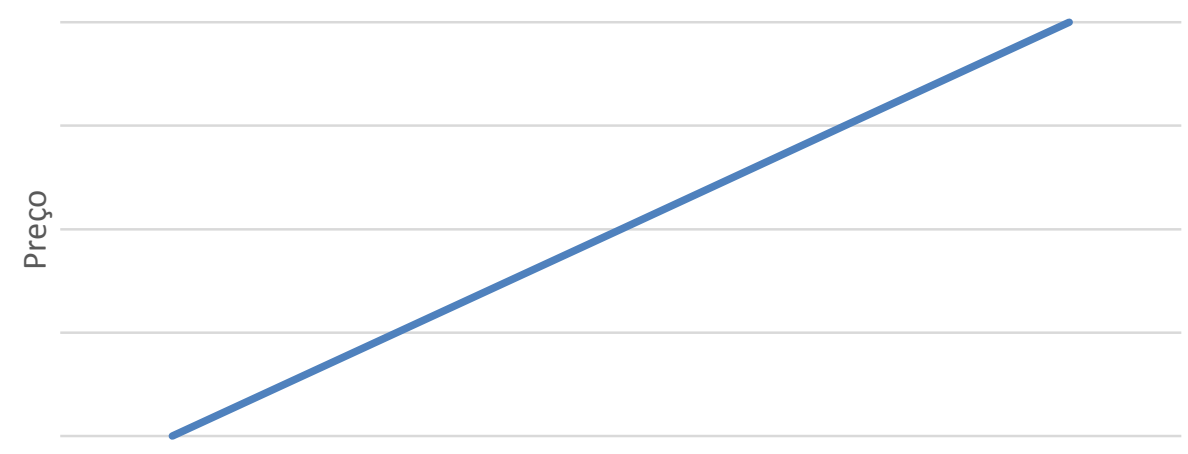

Quantidade

Fonte: NORDHAUS; SAMUELSON, 2006 
Percebe-se que a curva de oferta é positivamente inclinada no gráfico que relaciona quantidades e preços, ou seja, um preço menor provoca uma oferta menor de produtos e, onde o preço é maior, há uma maior oferta de bens e serviços. Havendo alteração em algum dos fatores acima, isso mudará a oferta dos produtos e serviços que estão sendo analisados (VIAN, 2009). Com isso, haverá deslocamento para cima caso haja aumento da oferta e, para baixo, em caso de diminuição da oferta (NORDHAUS; SAMUELSON, 2006, VIAN, 2009).

Um determinado mercado pode ser influenciado por vários fatores. Os mais óbvios são os econômicos, como preço dos bens relacionados e renda dos compradores. Se o preço de um determinado bem relacionado diminui, este produto se tornará mais atrativo aos compradores, ou seja, eles comprarão mais dos produtos com preços mais baixos e isso reduzirá o mercado do produto de interesse. Já um aumento na renda da população faz com que o interesse por diversos produtos aumente, sendo o impacto do aumento da renda diferente para produtos diferentes (ASCHE; BJORNDAL, 2011).

\subsubsection{Teoria de Organização Industrial}

Desde os primórdios, a Teoria de Organização Industrial (OI) esteve inspirada em questões de política pública. Seu nome e primeiros passos como disciplina nasceram em Harvard na década de 30 (FARINA, 1996). Os autores Scherer \& Ross (1990) definem o escopo da OI como sendo a análise de "como os processos de mercado orientam as atividades dos produtores no sentido de atender a demanda dos consumidores, como esses processos falham, como se ajustam ou podem ser ajustados, de sorte a alcançarem um desempenho, o mais próximo possível, de algum padrão ideal".

Scherer em 1980 foi ainda mais direto: "O objeto da Ol diz respeito a como as atividades produtivas e a demanda da sociedade são harmonizadas por meio de algum mecanismo organizacional com o livre mercado, e como variações e imperfeições neste mecanismo afetam o grau de sucesso alcançado pelos produtores em satisfazer os desejos da sociedade em termos de bens e serviços" (SCHERER, 1980:2-3 apud FARINA, 1996) 
Já segundo Coase (1972), o verdadeiro objetivo da Ol é determinar quais forças são responsáveis pela organização da indústria, como estas forças têm se alterado no tempo e que efeitos podem ser esperados de mudanças na forma de organização da indústria. Por firma entende-se uma unidade de ação que objetiva a maximização de seus resultados em termos de produção e lucro (GARÓFALO, 1995). Porém foi o trabalho de Ronald Coase que inspirou os avanços que dão sustentação ao que se convencionou chamar de Nova Economia Institucional, onde se desenvolveu um novo paradigma para o estudo das organizações, entendendo-se firma como uma relação orgânica entre agentes que se realiza através de contratos, sejam eles explícitos, como os contratos de trabalho, ou implícitos, como uma parceria informal. (ZYLBERSZTJAN, 2000) e, indústria, como um conjunto de firmas de um determinado bem ou serviço.

No âmbito da OI, configurações eficientes de mercado que, portanto, minimizam o custo da indústria dependem de uma hipótese fundamental: a existência de uma forte pressão competitiva (FARINA, 1996). Os autores da Ol reconhecem os problemas de informação, complexidade organizacional e incerteza que comprometem a maximização de lucros como o objeto único da firma.

Nas versões mais antigas dessa teoria econômica, as estruturas de mercado são determinadas exogenamente e dependiam das condições básicas de oferta e demanda, tais como taxa de crescimento dos mercados, hábitos e métodos de compra, sazonalidade do consumo e da produção, atributos tecnológicos dos produtos, insumos e processos, atitudes empresariais, aparato legal (SCHERER \& ROSS, 1990:5 apud FARINA, 1996).

Nas versões mais modernas, essas procuram tratar as estruturas dos mercados endogenamente, de forma que a conduta das empresas e seu desempenho são simultaneamente determinados, ao invés de haver uma relação causal e unidirecional entre eles. As estruturas de mercado apresentam determinantes tecnológicos (subaditividade de custos de produção, distribuição e de transação) que, combinados com as estratégias empresariais (investimentos em P\&D, propaganda, concorrência 
de preços, produto etc.) vão resultar em diferentes padrões de concentração (FARINA, 1996).

A Ol propõe-se a tratar das estratégias competitivas das firmas em condições de interdependência oligopolista e seus efeitos sobre o próprio ambiente competitivo (criação e sustentação de barreiras à entrada, expulsão de rivais efetivos e potenciais, exploração e extensão do poder de monopólio). Seus resultados são aplicáveis à orientação da política governamental, embora tratem dos efeitos das estratégias empresariais sobre o desempenho dos mercados. Esses mesmos resultados podem, de outro lado, orientar as empresas em suas estratégias competitivas, no sentido de obter lucros extraordinários no curto prazo ou no longo prazos (FARINA, 1996).

Michael Porter, em sua obra Vantagem Competitiva das Nações (1993), foi responsável por traduzir os fatos estilizados da OI para o mundo das empresas, estabelecendo condições para obtenção de vantagens competitivas que nada mais são do que assimetrias em relação aos concorrentes - vantagens de custo, informação, diferenciação, capacidade de criação e aproveitamento de oportunidades de investimento.

\subsubsection{Concentração Industrial}

As medidas de concentração pretendem captar de que forma agentes econômicos apresentam um comportamento dominante em determinado mercado e, dessa forma, os diferentes indicadores consideram as participações no mercado dos agentes, segundo diferentes critérios de ponderação (KUPFER, 2013).

Os mercados estão estruturados de maneira diferenciada em função de diferentes fatores, como por exemplo: o número de firmas produtoras atuando no mercado e a homogeneidade (igualdade) ou diferenciação dos produtos de cada firma (PASSOS; NOGAMI, 2005).

Assumindo diferentes formas, eles podem ser altamente organizados ou não. Mais frequentemente, os mercados são menos organizados, caracterizando um mercado competitivo. Isso significa que o preço e a quantidade de bens vendidos não são 
determinados por um único comprador ou vendedor, mas sim pelo conjunto de compradores e vendedores, conforme interagem no mercado (MANKIW, 2008).

O padrão concorrencial vigente, contudo, é o resultado da ação dos produtores individuais (conduta), ao escolherem os níveis de preço ou as quantidades ofertadas, as características específicas dos produtos fabricados, as preferências dos consumidores e as condições de acesso. As taxas de preferência intertemporais dos agentes, seus graus de informação e seus coeficientes de aversão ao risco (incerteza) são fatores que influenciam as tomadas de decisão (KUPFER, 2013).

O padrão concorrencial contribui para dar uma estrutura particular à indústria, como consequência do desempenho das empresas e dos resultados obtidos, vale dizer: dados os recursos empregados, como consequência da maior ou menor eficiência produtiva alcançada e da maior ou menor eficiência gerencial obtida. Os resultados obtidos pela empresa lhes conferem, pelo seu lado, um determinado "poder de mercado" individual no seio da indústria (KUPFER, 2013).

Para o caso de produtos diferenciados, esse poder está relacionado com sua capacidade de controlar o preço de venda do produto. Por isso, empresas mais eficientes, que produzem com custos de produção mais baixos, têm mais facilidade que as demais de competir em preço e de ocupar parcelas crescentes do mercado por meio de reduções progressivas no preço. Mais do que isso, o poder de mercado de uma empresa se manifesta pela sua capacidade de fixar e sustentar o preço de venda em um nível acima daquele fixado pelas concorrentes, sem prejuízo para sua participação no mercado (KUPFER, 2013).

\subsubsection{Diferenciação de produtos}

Quando consumidores consideram os produtos idênticos, ou seja, substitutos perfeitos, a ocorrência de preços distintos não permite à empresa com preço superior realizar vendas, pois os consumidores optam por adquirir apenas da empresa com preço menor. Por isso, quando são considerados mercados sem diferenciação de produtos, respeitando as demais condições competitivas, o preço é único, sendo definido pelo mercado. Nesse caso, as empresas são tomadores de preços, já que 
não podem influenciar o preço de mercado e, na verdade, se deparam com curvas de demandas perfeitamente elásticas (KUPFER, 2013).

Algumas vezes consumidores se dispõe pagar preços superiores pois, os produtos encontrados nos pontos de venda dificilmente são idênticos. O que explica esse comportamento é a diferenciação do produto, que pode ser resultante de diversos aspectos como: local da oferta, qualidade do produto ou percepção da marca. Rigorosamente, basta que os consumidores percebam os produtos como diferentes, isto é, que tenham preferências subjetivas distintas, para ocorrer diferenciação de produto (KUPFER, 2013).

Para ter poder de mercado, as empresas podem utilizar-se da diferenciação de produtos - uma vez que são substitutos imperfeitos - fixando assim preços acima das demais e realizar venda. Essa estratégia pode tornar-se importante, na medida em que a maior parte das empresas produz uma grande variedade de bens/serviços. (KUPFER, 2013).

\subsubsection{Barreiras à entrada}

Foi a partir do trabalho de Joe S. Bain, nas décadas de 1940 e 1950, que, nas teorias de Economia Industrial, a existência ou não de barreiras à entrada na indústria tomou forma, ou seja, consolidou-se a ideia de que o principal fator na determinação dos preços e da lucratividade em uma indústria está relacionado à facilidade ou à dificuldade que as empresas estabelecidas encontram para impedir a entrada de novas empresas (KUPFER, 2013).

Bain (1956) especificou três fontes de barreiras à entrada: vantagens absolutas de custo, economias de escala e vantagens da diferenciação dos produtos de empresas incumbentes, como por exemplo, reputação (CARLTON \& PERLOFF, 1994; SHY, 1995). Além disso os políticos e todos os níveis de governo podem explicitar ou implicitamente dar suporte às empresas existentes. Outras razões incluem a experiência adquirida pelas empresas existentes, lealdade dos consumidores às marcas que já consumem e disponibilidade de financiamento (SHY, 1995). 
As barreiras à entrada são consideradas uma característica estrutural importante de uma indústria. A competitividade e o desempenho de uma indústria são geralmente são fortemente influenciados por suas condições de entrada (SHY, 1995).

A definição para barreiras à entrada segundo Carlton \& Perloff (1994) é tudo aquilo que impede um empreendedor de instantaneamente criar uma nova firma no mercado, porém, esta definição é bastante generalista. Assim, uma abordagem razoável é se concentrar em barreiras de longo prazo à entrada, que impedem que novas empresas entrem no mercado, apesar de uma empresa existente ganhar lucros de longo prazo.

Se existem muitas empresas que podem entrar com curvas de custo iguais e enfrentar preços idênticos, então nenhuma empresa pode ter sucesso no longo prazo em ganhar os lucros que excederem os custos sem indução de entrada adicional. Só por ter alguma vantagem sobre os concorrentes uma empresa pode obter lucros mais elevados do que outras empresas existentes ou potenciais. Como os lucros a longo prazo só podem persistir se uma empresa tiver vantagem sobre entrantes potenciais, uma definição lógica para barreira à entrada de longo prazo seria o custo que deve ocorrer sobre um novo operador que as empresas existentes não poderiam suportáIo (CARLTON \& PERLOFF, 1994).

A teoria da organização industrial auxiliará na análise conclusiva desta pesquisa de como os processos reais de mercado estão orientando os produtores a atenderem a demanda por tilápia, o que está falhando e o que pode ser ajustado para atingir um padrão satisfatório.

\section{Materiais e Métodos}

Uma vez que dados sobre o mercado da tilápia são escassos na literatura, uma pesquisa exploratória foi realizada. Segundo Raupp; Beuren (2003), esse tipo de pesquisa deve ser utilizado quando há pouco conhecimento sobre a temática a ser abordada. Alguns métodos adotados em pesquisa exploratória de acordo com Vieira (2002) são: levantamentos em fontes secundárias, levantamentos de experiência, estudos de casos selecionados e observação informal. 
Além da abordagem exploratória, realizou-se uma abordagem descritiva, por estas serem amplamente utilizadas em estudos de mercado e terem como objetivo a descrição das características de determinado fenômeno, incluindo as pesquisas que intencionam conhecer opiniões e atitudes. Para essa finalidade, dentre as técnicas de coleta de dados, utiliza-se a aplicação de questionários (DAYAN, 2004; SAMPIERI; COLLADO; LUCIO, 2006; GIL, 2009; GRAY, 2012).

As fontes de dados para descrever os determinantes da oferta e demanda nesta pesquisa serão primárias e secundárias. Dados primários são novos e coletados para um projeto específico de pesquisa e, dados secundários são dados que já foram coletados para outra finalidade e podem ser encontrados em fontes diversas (KOTLER, 2006).

Foram utilizados como instrumentos de pesquisa para a coleta de dados primários questionários - instrumento mais usado para este fim, e que consiste em um conjunto de perguntas que são feitas aos entrevistados - formulado com perguntas abertas e fechadas. As perguntas abertas, segundo Kotler (2006), são particularmente úteis em pesquisas exploratórias, em que o pesquisador está interessado em saber como as pessoas pensam, e não mensurar quantas pessoas pensam de determinado modo.

Para a identificação e descrição dos produtos comercializados, uma pesquisa a campo foi realizada em quatro lojas de redes varejistas nacionais, na cidade de Piracicaba, semanalmente, durante quatro meses (de janeiro a abril de 2015), totalizando 16 semanas. Durante a visita eram visitadas as áreas de peixaria fresca e peixaria congelada, observando-se o tamanho das embalagens, tipo de processamento, se o produto era vendido a granel ou embalado, marca, endereço do frigorífico e preço por quilo.

As quantidades de tilápia comercializadas no estado e o preço foram obtidos de três formas: 1) entrevista não estruturada a produtores e especialistas do setor, 2) visita ao principal mercado atacadista do estado, e 3) - entrevista estruturada (Apêndice I) com representantes de duas redes varejistas do estado. 
Entrevistas não estruturadas foram realizadas com especialistas e representantes setoriais durante as reuniões mensais do COMPESCA - Comitê de Pesca e Aquicultura do estado de São Paulo, da FIESP, a fim de se obter informações sobre a organização do setor, investimentos e expectativas.

Quanto às quantidades de tilápia consumidas, foram analisados dos dados da pesquisa POF (Pesquisa de Orçamento Familiar) do IBGE (Instituto Brasileiro de Geografia e Estatística) de 2008-2009 - que são os últimos dados disponibilizados pelo instituto e os resultados obtidos de um questionário aplicado a consumidores, durante o mês de março de 2015.

Tal questionário continha 21 perguntas (Apêndice II) e foi aplicado via internet a 203 consumidores moradores do estado de São Paulo, com o intuito de avaliar os determinantes da demanda preço do bem, renda e preferências. Tal meio de levantamento de dados oferece vantagens de custo, rapidez, tendência das pessoas serem mais honestas do que em entrevistas pessoais e mais versátil (Kotler, 2006), além de se conseguir uma amostragem que contou com respostas de pessoas de diferentes cidades do estado.

O questionário foi testado previamente com uma amostra de sete pessoas para verificar o entendimento das perguntas, a facilidade em responder e a coerência das opções de resposta, além verificar se todas as questões relevantes para os resultados desta pesquisa estavam contempladas. Após os testes e os respectivos ajustes necessários, houve divulgação ampla da pesquisa com a versão final do questionário. Esta etapa foi realizada por e-mail e pelas mídias sociais para uma base de contatos pessoal e junto a especialistas e um grupo de discussão do setor.

Paralelamente, um levantamento de dados secundários foi realizado durante o período da pesquisa para complementar a análise do mercado de tilápia. Para isso, foram consultadas instituições de pesquisa e representativas do setor, tais como:

1) CEAGESP: um levantamento das informações de preço de venda da tilápia e outras espécies de pescado fornecidas por essa instituição foi realizado e, com tais dados foi possível entender, em comparação com os preços levantados diretamente no 
varejo, a diferença na precificação do produto e o impacto para o consumidor. Além disso, essa instituição apresenta uma série história de preços, sendo assim, analisar tal base de dados permitiu compreender as variações no preço em diferentes períodos do ano e, comparar o preço da tilápia com outras espécies.

2) Fiesp (Federação da Indústria do Estado de São Paulo), ABIA (Associação Brasileira das Indústrias da Alimentação), APAS (Associação Paulista de Supermercados) e ABRAS (Associação Brasileira de Supermercados): com o objetivo de identificar o número de supermercados, peixarias e lojas especializadas em pescado no estado de São Paulo, visando conhecer-se a quantidade de tilápia comercializada no estado.

3) Projeto Índice de Preços ao Consumidor (IPC) da Fundação Instituto de Pesquisas Econômicas - Fipe): para o fornecimento dos dados mensais de preço no varejo cotados pela instituição para as seguintes espécies de pescado: camarão, corvina, cação, merluza, sardinha e pescada.

A fim de complementar as análises sobre a demanda agregada, principalmente no que diz respeito ao preço, os dados mensais de preço no varejo, cotados pelo Projeto Índice de Preços ao Consumidor (IPC) da Fundação Instituto de Pesquisas Econômicas - Fipe) para as espécies camarão, corvina, cação, merluza, sardinha e pescada foram utilizados em análise estatística para se identificar as espécies que mais se relacionam com a tilápia. Uma análise de correlação e uma regressão linear múltipla foram realizadas para checar o efeito do preço dessas espécies sobre o preço da tilápia, assumindo-se a seguinte fórmula:

$$
\text { Ptilápia }=A+B \cdot \text { pescada }+ \text { C. sardinha }+ \text { D.cação }+ \text { E.corvina }+ \text { F.camarão }
$$

O modelo de regressão foi estimado pelo método dos mínimos quadrados ordinários. Para a realização de tais análises, os preços nominais foram deflacionados, utilizando-se o Índice Nacional de Preços ao Consumidor (INPC/IBGE).

Por fim, os dados de exportação foram obtidos junto ao banco de dados da Secretaria de Comércio Exterior (SECEX), na plataforma eletrônica Aliceweb 
(http://aliceweb.mdic.gov.br/) e do USDA (United States Department of Agriculture). Esses dados foram processados em planilha eletrônica. As informações quantitativas apresentadas foram analisadas contrapondo-as com resultados de pesquisas bibliográficas e entrevistas com agentes do setor, a fim de se obter dados da demanda no mercado internacional.

\section{Resultados e Discussão}

A tilápia começou a ganhar expressividade no estado de São Paulo por volta da década de 80 , quando começaram a surgir os pesque-pague como forma de atividade esportiva alternativa à pesca, até então muito realizada no estado do Mato Grosso. Com o avanço desta atividade, tornou-se necessário criar determinadas espécies de peixe em lugares próximos a estes locais, favorecendo então o suprimento e a logística de peixes para a prática do lazer.

Além deste avanço, estudos na parte de genética e tecnologia para a melhoria da criação de tilápia foram desenvolvidos, por universidades e institutos de pesquisa, até atingir-se a situação atual, que é de conhecimento de técnicas e práticas que fazem da tilapicultura uma atividade produtiva economicamente viável.

Com esse desenvolvimento tecnológico, um dos ganhos obtidos foi na qualidade da carne da tilápia - branca, de sabor suave e sem espinhas na forma de "Y" -, o que motivou os produtores a começarem a ofertar em maior quantidade esta espécie de peixe para os canais de venda ao consumidor final.

Apesar deste cenário que favorece o desenvolvimento da atividade, a falta de estatísticas e bases de dados históricas e confiáveis, além da aparente falta de união dos produtores e desinteresse na disponibilização de informações sobre a produção, podem ser apontadas como alguns dos gargalos para a análise e projeções desse mercado e definição de estratégias e investimentos para a tilapicultura.

Algumas informações sobre produção foram encontradas, porém, com dados que são questionados pelos próprios integrantes do setor. Devido à pulverização e heterogeneidade dos produtores, houve dificuldade de se concluir a respeito do real número de produtores e suas capacidades produtivas. Diversos produtores 
contatados mostraram-se resistentes a abrirem suas informações. Porém, segundo dados de especialistas, a produção de tilápia no estado em 2014 foi de aproximadamente 50.000 a 55.000 toneladas.

De acordo com o levantamento realizado junto a profissionais do mercado em questão, identificou-se que o sistema agroindustrial da tilápia está atualmente organizado da seguinte forma:

Figura 8 - Representação esquemática do Sistema Agroindustrial da Tilápia no estado de São Paulo.

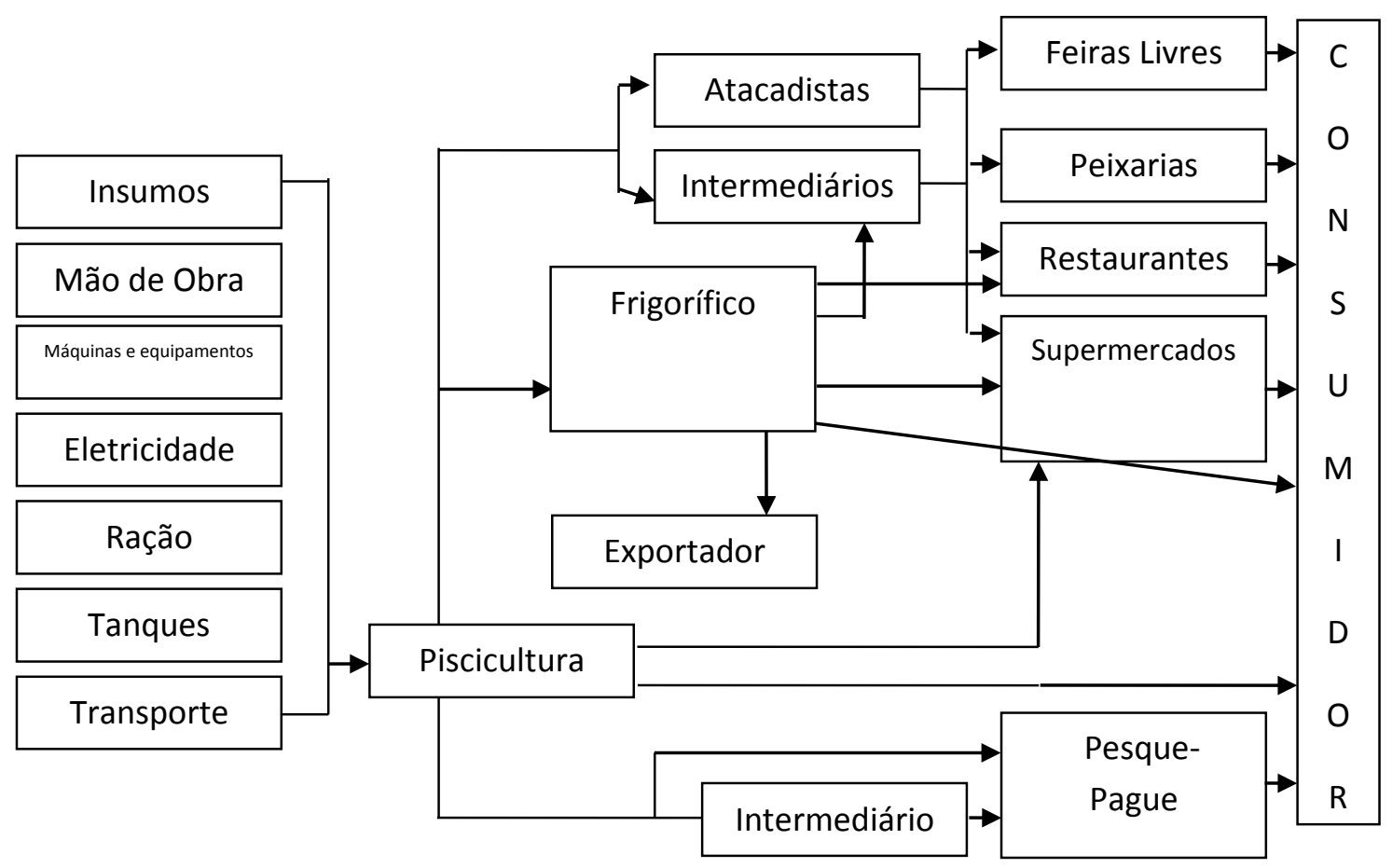

Fonte Adaptado de Sonoda (2002) e baseado em informações de profissionais do mercado.

Na representação esquemática acima é possível visualizar os agentes desta cadeia. São esses os fornecedores de insumos, máquinas e equipamentos, energia elétrica, tanques, ração, transporte e a mão de obra. Os produtores (piscicultores) podem ser produtores de alevinos, responsáveis pela engorda ou ambos. Atingido o peso entre $800 \mathrm{~g}$ e $1.100 \mathrm{~g}$, as tilápias são comercializadas vivas para os frigoríficos, pesquepague ou intermediários, que farão o transporte da área produtiva para o pesqueiro. Também podem ser comercializadas abatidas diretamente ao consumidor final, exportadores, entrepostos, intermediários ou varejistas. O varejo, elo mais próximo 
dos consumidores finais, é caracterizado neste mercado pelas feiras livres, supermercados e peixarias.

A questão da verticalização da tilapicultura, assim como acontece com algumas cadeias produtivas de proteína animal, como a do frango, ainda não está bem definida. Algumas empresas estão recebendo suas licenças ambientais e investindo em fábrica de ração, frigorífico e produção de alevinos, principalmente no polo de produção da região de Santa Fé do Sul, no Noroeste de São Paulo, com plantas capazes de processar toda a produção de tilápia de suas áreas particulares.

Porém, segundo especialistas, há também aqueles produtores menores - em maior quantidade - que estão focando apenas na produção dos peixes, vendendo sua produção para abatedouros processarem (abate, evisceração, filetagem e embalagem) e comercializarem. No estado, foram constatados apenas dois casos de empresas que estão investindo em um modelo verticalizado. Portanto, os resultados desta pesquisa permitiram observar que a verticalização não é um consenso, e que, o setor ainda busca uma definição sobre o que é melhor para esta cadeia.

Os produtores que estão abastecendo as redes varejistas são os de grande porte, que em muitos casos possuem frigorífico próprio. Os produtores menores fornecem para o pesque-pague e mercado local (venda direta ao consumidor final). Tais informações puderam ser obtidas através das pesquisas a campo e por meio das informações fornecidas pelos produtores consultados.

As empresas frigoríficas de grande porte têm, em sua maioria, parte do volume abatido e comercializado vinda de criação própria. Dependendo da época e da capacidade do abatedouro, é possível que a empresa compre peixe produzido por terceiros, através de parceria, sem contrato, apenas com um volume de peixe negociado para ser fornecido por semana. Há outras, contudo, que só compram peixe de terceiros que usaram a ração fornecida pela empresa - modelo este mais próximo da integração praticada por outras cadeias.

\subsection{Produtos comercializados}

Cada opção de escoamento da produção de tilápia tem suas particularidades quanto à forma de apresentação do produto. De acordo com a legislação brasileira, o pescado 
pode ser classificado como fresco ou congelado e, ainda, pela forma de apresentação, inteiro ou eviscerado. Os filés, são classificados como "congelados rapidamente", blocos de filés de pescado e misturas de filés, de acordo com o Regulamento para Inspeção Industrial e Sanitária de Alimentos de Origem Animal (Riispoa), de 1952.

Neste mercado foram identificados três tipos de produtos vendidos ao consumidor final, que são:

- $\quad$ Tilápia inteira eviscerada;

- Tilápia em filé fresco; e

- $\quad$ Tilápia em filé congelado.

Em todas as lojas de redes de supermercados visitadas na cidade de Piracicaba havia tilápia fresca e congelada. A tilápia inteira eviscerada fresca foi encontrada para venda a granel. Já a tilápia fresca em filé é vendida a granel, em bandejas de isopor embaladas pelo próprio supermercado (normalmente embalagens de até $500 \mathrm{~g}$ ) ou embalada a vácuo (embalagem de $500 \mathrm{~g}$ ). Dentre esta categoria de peixe fresco, apenas o peixe embalado a vácuo possui o nome do produtor, marca e indicação de SIF.

A tilápia em filé congelado é a que traz na embalagem o maior número de informações ao consumidor: nome do produtor, marca, SIF, tabela nutricional e receita. As embalagens encontradas foram sacos plásticos, de $250 \mathrm{~g}$ a $1 \mathrm{~kg}$, podendo o peixe ser congelado no pacote ou congelados individualmente (IQF - Individual Quick Frozen). Com relação às marcas, foram identificadas oito marcas de produto congelado, sendo quatro do Estado de São Paulo. Uma destas marcas paulistas é própria de uma rede de supermercados, ou seja, de marca própria, encontrada em duas lojas das quatro visitadas. 
5.2 Quantidades comercializadas e consumidas

\subsubsection{Quantidades comercializadas no atacado}

Por atacado entendem-se todas as atividades relacionadas com a venda de bens ou serviços para aqueles que compram para revenda ou uso comercial. Não fazem parte do atacado os fabricantes e agricultores, que lidam basicamente com a produção (KOTLER, 2006).

No estado de São Paulo há um canal importante para o escoamento da produção de tilápia por atacado. A CEAGESP (Companhia de Entrepostos e Armazéns Gerais de São Paulo) é o maior entreposto de pescado da América Latina e atende o mercado consumidor da capital do estado, além de outras cidades do país.

O entreposto de pescado é frequentado por feirantes, restaurantes, peixarias, supermercados, comerciantes informais, hospitais, instituições de caridade e hotéis. Funciona de terça-feira a sábado, das $02 \mathrm{~h}$ às $06 \mathrm{~h}$, sendo o horário de maior movimento nas vendas às $3^{\text {a }}$ s feiras, entre as $02 \mathrm{~h}$ e $03 \mathrm{~h} 30$. O local de comercialização de pescado é composto por três pátios: (1) pátio central onde são vendidas diferentes espécies de pescado; (2) venda principalmente de pescado congelado; e (3) pátio da sardinha - conhecido assim por, antigamente, ser exclusivo para a venda desta espécie (informação verbal) ${ }^{3}$

Atualmente pode-se encontrar nesse mercado mais de 97 espécies de pescado na forma inteira fresca, eviscerada, congelada inteira, congelada eviscerada, sem cabeça e sem vísceras congelada e resfriada, filé industrializado e postas congeladas. $O$ volume total comercializado no ano de 2014 foi de 153.614 toneladas e o período do ano com maior venda no entreposto é durante a Semana Santa, podendo chegar a 400 toneladas em um dia.

A venda de tilápia na CEAGESP em 2014 atingiu 3,9 mil toneladas, o maior volume registrado até então para a espécie. Este valor representa 34,5\% a mais do que o ano

\footnotetext{
${ }^{3}$ Informações obtidas durante visita ao mercado da CEAGESP, em conversa com o responsável pela cotação diária do pescado, Sr. Wagner Ferrarini.
} 
2013 e, em comparação ao ano 2010, evidencia crescimento de 135\%. Abaixo encontra-se um gráfico com o histórico de preço e volume de tilápia inteira comercializada na Companhia.

Figura 9 - Histórico de preço real (dez/2014) e volume (em kg) de tilápia inteira comercializada no atacado (2001-2014)

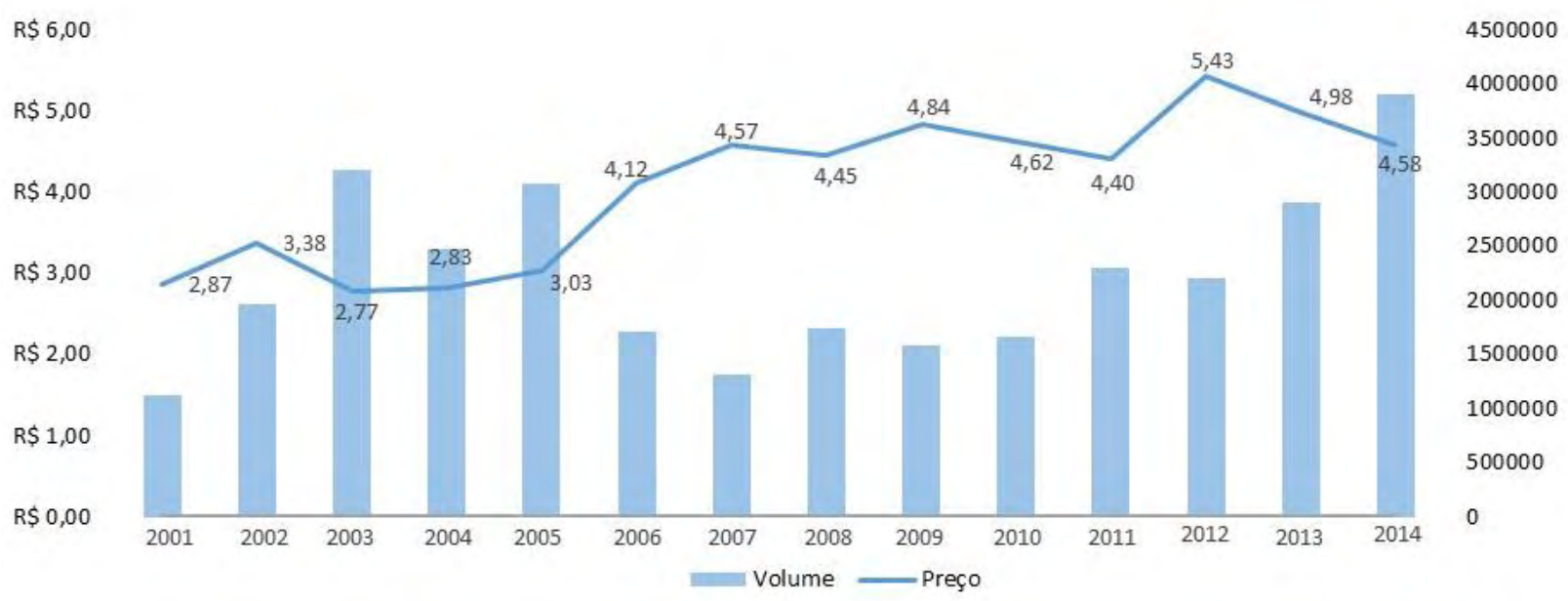

Fonte: CEAGESP

$\mathrm{Na}$ figura 10, abaixo, é possível analisar a sazonalidade da venda de tilápia no mercado atacadista. Comparando-se os dados mês a mês de 2011 a 2014, nota-se aumento das vendas de fevereiro até abril e, tendência de aumento a partir de agosto, mantendo-se de outubro a dezembro, conforme já constatado por Sonoda (2002).

Analisando-se o volume de venda mensal em 2013 nesta mesma figura, percebe-se aumento da quantidade comercializada no período de agosto a dezembro, sendo este último, o mês de maior venda do mercado atacadista para a espécie em questão. Em 2014 o volume comercializado em outubro e novembro foi menor do que no ano anterior, porém, durante todo o ano o volume de tilápia foi superior a 2013, o que representou, ao final de um ano, aumento de 1.000 toneladas só desta espécie. 
Figura 10 - Sazonalidade de venda (em kg) de tilápia no atacado (2011-2014)

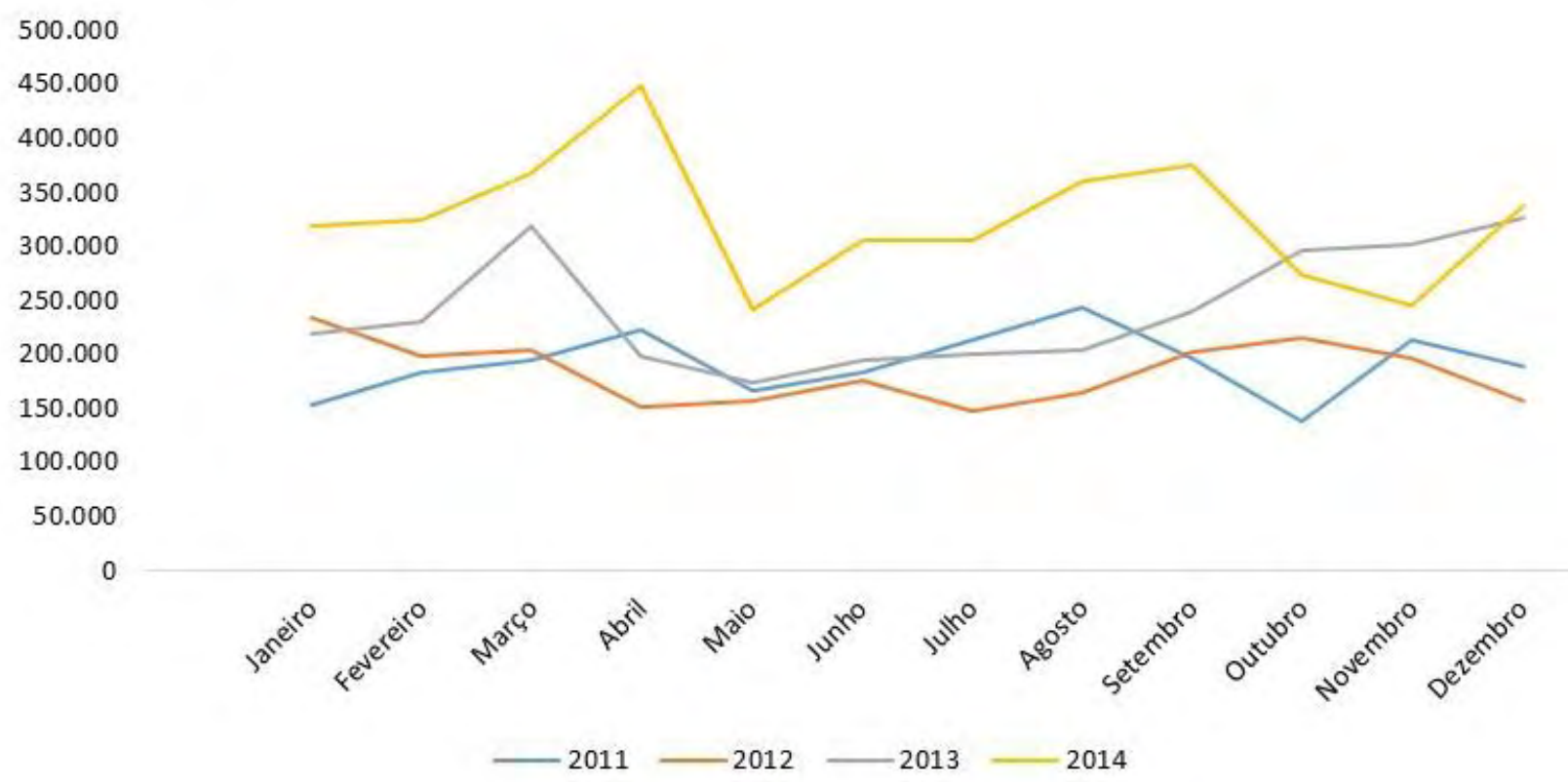

Fonte: CEAGESP

Todos os valores apresentados para esta análise do mercado atacadista referem-se ao produto que representa $95 \%$ das vendas de tilápia neste canal de comercialização: tilápia inteira. Filés representam apenas $5 \%$ e não foram contabilizados para esta análise do atacado.

Os fornecedores de tilápia para o canal atacadista da CEAGESP são em sua maioria do estado de São Paulo, porém, durante visita ao mercado, constatou-se a presença de peixes criados em Minas Gerais e Paraná.

\subsubsection{Quantidades comercializadas no varejo}

As vendas a varejo são aquelas realizadas aos consumidores finais (SOUZA BARROS et al. 1978). Um varejista ou uma loja de varejo é qualquer empreendimento comercial cujo faturamento provenha principalmente da venda de pequenos lotes (KOTLER, 2006). No caso da tilápia, os tipos de lojas varejistas podem ser definidos como: peixarias, feiras livres e supermercados. 
A maioria dos consumidores compra peixe nos supermercados. Tal afirmação foi constatada por Tavares (2013), Kubitza (2002) e na pesquisa realizada juntos aos consumidores finais para este estudo. Ocasionalmente alguns compram em mercados locais e lojas especializadas, como feira e peixarias.

O papel do peixeiro na hora da compra é indicado como importante pelos consumidores. A decisão final da compra é fortemente influenciada pela confiança na pessoa que está vendendo a eles o produto, segundo um estudo americano (PEAVEY, 1994).

O consumidor tem preferência por peixe fresco e isso foi observado com os dados de venda das redes varejistas nos últimos anos. Em 2014, a participação média da venda de peixe fresco foi $59 \%$ do total. Com relação às vendas de tilápia, o consumo também foi maior para os produtos frescos $-70 \%$ do total - , porém, menos de $0,3 \%$ desse volume é de filé de tilápia fresco, sendo, portanto, o maior volume comercializado de tilápia inteira eviscerada fresca. Comparando-se venda de filé de tilápia fresco e congelado no varejo, a participação na venda de filé de tilápia congelado é maior. Dados obtidos via entrevista com duas redes varejistas mostram uma venda nacional de mais de 1,5 mil toneladas de tilápia em 2014.

A sazonalidade de venda da tilápia no varejo, de forma geral, analisando-se o ano 2014, acompanhou a das demais espécies. Entretanto, comparando a venda de tilápia no varejo e no atacado durante $o$ ano, percebe-se que a sazonalidade é semelhante apenas no primeiro semestre, enquanto que, no segundo, a alta nas vendas é identificada apenas no atacado. No varejo, a venda de tilápia no segundo semestre fica constante, com leve alta entre os meses de novembro e dezembro. 
Figura 11 - Comparação entre venda (em kg) de pescado no varejo e tilápia no atacado e no varejo. Dados referentes a 2014

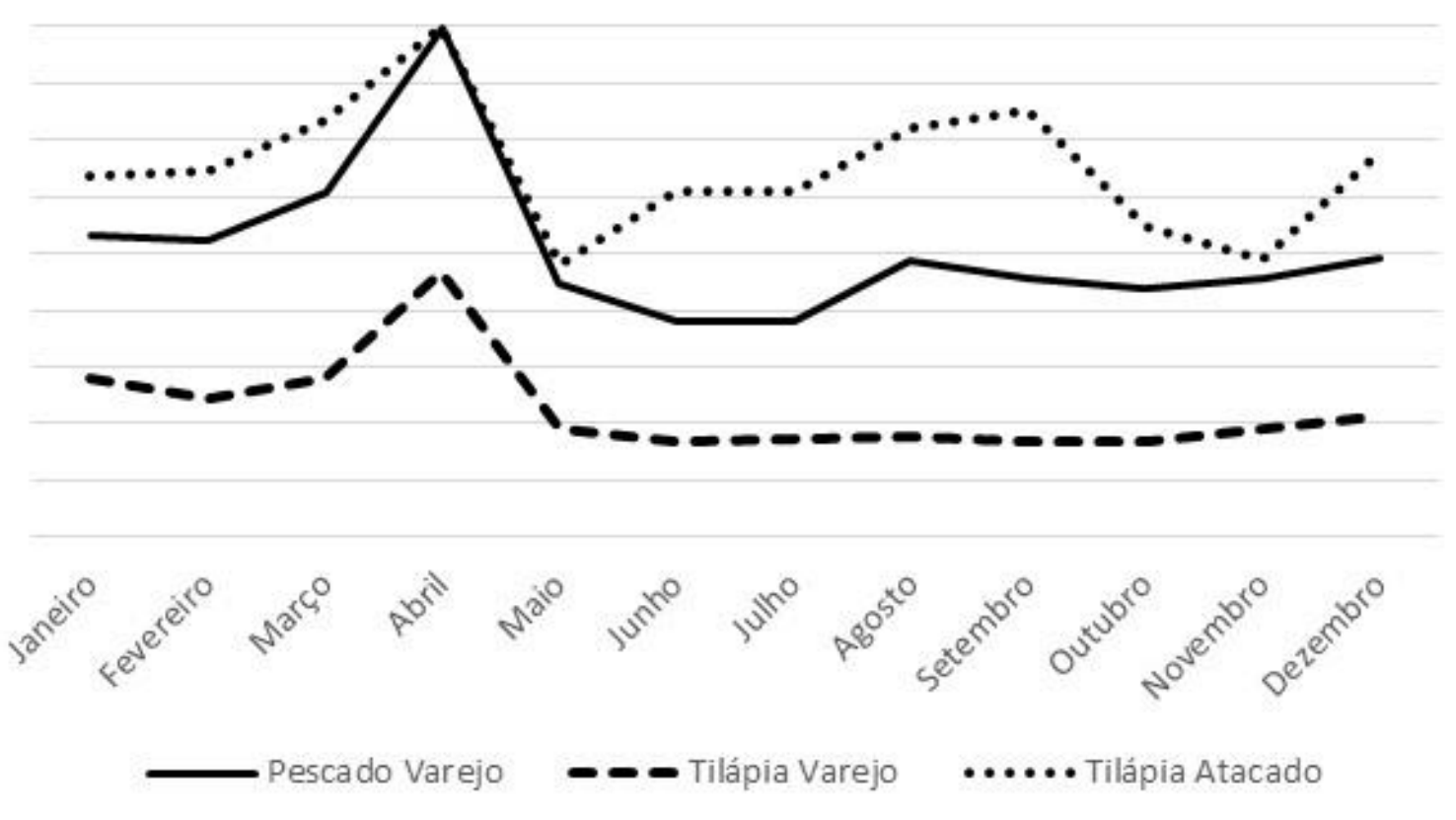

Fonte: da própria autora

Para os varejistas, trabalhar com um peixe de aquicultura é uma vantagem pois consegue-se ter previsibilidade da oferta. Acredita-se que a tilápia e o salmão sejam duas espécies que se enquadram nessa questão. Consegue-se abastecer a peixaria todas as semanas com peixe fresco, de qualidade, a um preço previamente conhecido e o consumidor geralmente encontra o produto disponível quando vai às compras.

Uma questão levantada pelos varejistas foi que eles não têm fornecedores suficientes para atender a demanda de produto na forma como eles querem, ao contrário de outros peixes que são importados. Ainda, informaram, ao contrário do que constatado por Sussel (2011), que o volume produzido no estado de São Paulo não atende toda a demanda, sendo preciso, em períodos de maior venda, comprar peixe de estados da região Sul e Minas Gerais.

Os varejistas também comentaram que o produto brasileiro não possui qualidade padronizada, ou seja, os produtores nacionais de tilápia não produzem volume 
suficiente para atender a demanda, o preço não é competitivo comparado a outros filés de peixe importados e o padrão não é mantido a cada entrega, o que desfavorece a fidelização dos consumidores e dificulta a percepção de qualidade das marcas.

A tendência da peixaria no varejo é o produto vir cada vez mais pronto para o consumo, direto do fornecedor; acabados, temperados, embalados. Dessa forma, evita-se processamento dentro da loja, diminui o custo para o varejo e atende exigência do consumidor por produtos mais convenientes.

Dos produtos comercializados no varejo, apenas uma empresa varejista paulista apresentou filé de tilápia fresco embalado a vácuo, diferenciando-se das demais. Este produto poderá vir a tornar-se uma tendência devido à qualidade, higiene, praticidade e conveniência que oferece.

Para o levantamento de dados estatísticos sobre o número de lojas, venda, consumo e preço de pescado, as instituições APAS, ABRAS, ABIA e FIESP foram consultadas, porém, nenhuma delas possui tais informações.

\subsubsection{Quantidade consumida}

Em 2008 os brasileiros consumiram, de acordo com os dados da Pesquisa de Orçamento Familiar (POF), mais de 771 mil toneladas de pescado. Essa quantidade é ligeiramente inferior à levantada na pesquisa anterior realizada no ano de 2002, que apresentou consumo de 775 mil toneladas. O consumo de pescado por região do país pode ser visto na tabela abaixo: 
Tabela 4 - Consumo de pescado por região brasileira

\begin{tabular}{|c|c|}
\hline Estado & Quantidade (kg) \\
\hline PA & $139.604 .067,21$ \\
\hline AM & $102.927 .894,01$ \\
\hline SP & $75.449 .082,71$ \\
\hline MA & $68.161 .595,17$ \\
\hline RJ & $54.956 .184,86$ \\
\hline BA & $52.581 .293,05$ \\
\hline CE & $46.876 .716,46$ \\
\hline PE & $28.874 .477,71$ \\
\hline MG & $27.805 .420,01$ \\
\hline RN & $18.149 .427,62$ \\
\hline RS & $17.430 .710,14$ \\
\hline PI & $15.229 .633,46$ \\
\hline PR & $14.708 .274,25$ \\
\hline PB & $12.645 .781,59$ \\
\hline AL & $12.318 .351,74$ \\
\hline SE & $12.166 .092,76$ \\
\hline SC & $12.103 .142,51$ \\
\hline AM & $9.669 .810,30$ \\
\hline ES & $8.118 .593,68$ \\
\hline AC & $7.443 .646,78$ \\
\hline GO & $7.278 .320,79$ \\
\hline DF & $6.623 .750,81$ \\
\hline RO & $5.364 .913,43$ \\
\hline MT & $4.624 .515,83$ \\
\hline MS & $3.978 .763,63$ \\
\hline RR & $3.656 .189,73$ \\
\hline TO & $3.130 .608,14$ \\
\hline Brasil & $771.877 .258,38$ \\
\hline FOn: \\
\hline 0
\end{tabular}

Fonte: POF 2008-2009

O estado de São Paulo, segundo os dados da pesquisa, foi o 3ํㅡaior consumidor de pescado do país, sendo responsável por 75 mil toneladas de pescado consumidas, 0 que representa 4,39\% a menos do que a pesquisa anterior (POF 2002-03). Uma parte dessa queda foi impactada pelo consumo de tilápia, que reduziu 58\% no estado, na comparação entre as duas pesquisas; no Brasil, o consumo de tilápia aumentou 32\%. 
O total de tilápia consumida em São Paulo, de acordo com a última POF disponibilizada, foi de 1,4 mil toneladas, sendo assim o $4^{\circ}$ estado maior consumidor de tilápia do Brasil, ficando atrás apenas de Ceará, Paraná e Rio Grande do Norte respectivamente, conforme tabela abaixo:

Tabela 5 - Consumo de tilápia por região brasileira (em kg)

\begin{tabular}{|c|c|}
\hline Estado & Quantidade (kg) \\
\hline CE & $7.778 .461,16$ \\
\hline PR & $2.693 .916,49$ \\
\hline RN & $2.473 .265,46$ \\
\hline SP & $1.440 .771,65$ \\
\hline PE & $1.244 .928,41$ \\
\hline SC & $1.163 .218,75$ \\
\hline PB & $1.144 .665,96$ \\
\hline MG & $1.084 .568,00$ \\
\hline PI & $536.019,11$ \\
\hline BA & $375.054,46$ \\
\hline AL & $276.957,69$ \\
\hline SE & $201.450,84$ \\
\hline MA & $154.251,12$ \\
\hline DF & $148.548,38$ \\
\hline ES & $61.764,63$ \\
\hline GO & $56.477,28$ \\
\hline MS & $55.734,87$ \\
\hline TO & $33.436,16$ \\
\hline AC & $13.123,39$ \\
\hline MT & $7.161,18$ \\
\hline Brasil & $\mathbf{2 0 . 9 4 3 . 7 7 4 , 9 9}$ \\
\hline Fonte: POF $2008-09$ \\
\hline
\end{tabular}

Ainda segundo os dados da POF, $79 \%$ do volume de tilápia consumido no Brasil é na forma inteira, sendo o restante, filé congelado (12\%), filé fresco $(5 \%)$, em postas $(3 \%)$ e salgado (1\%). Os dados do varejo para 2014 também mostram predominância da tilápia inteira fresca, seguida dos filés congelado e fresco, respectivamente. 
Ao contrário das duas referências anteriores, a pesquisa realizada para este estudo mostrou que, dos paulistas que consomem tilápia, $47 \%$ compra filé sem pele e congelado, $36 \%$ filé sem pele e fresco e, apenas $14 \%$ a tilápia inteira.

Esta mesma pesquisa identificou que, das 203 pessoas que responderam o questionário, 161 consomem menos de $100 \mathrm{~g}$ do peixe por semana, ou seja, $79 \%$, sendo que, quando questionados sobre a quantidade da proteína animal que mais consumem durante a semana, a resposta foi acima de $300 \mathrm{~g}$ para $64 \%$ dos entrevistados. Dentre os motivos que fazem com que os paulistas não comam mais tilápia estão: a) falta de hábito de comprar (49\%), b) não encontrar no local onde faz compras $(23 \%), c)$ preço alto $(21 \%)$ e d) não ter esta opção no restaurante que frequenta $(20 \%)$.

O consumo nacional de pescado é baixo devido aos altos preços do produto final, aos hábitos alimentares da população - que valoriza o consumo da carne bovina e, à falta de qualidade, diversidade e praticidade oferecidas pelos produtos à base de peixe comercializados (BOMBARDELLI et al., 2005; SONODA, 2006; OSTRENSKY et al., 2007 apud Tavares, 2013) ${ }^{4}$.

5.3 Quantidade de consumidores e preferências

\subsubsection{Dados POF 2008-2009}

O estado de São Paulo possuía em 2008 aproximadamente 40 milhões de habitantes segundo dados da POF. Em 2014 esse total passou para 44 milhões segundo dados do IBGE (2014). De acordo com aquela mesma pesquisa, o consumo de tilápia no Brasil foi $75 \%$ realizado pelas pessoas com faixa de renda menor que $R \$ 2.490,00$, segundo tabela 6 .

\footnotetext{
4 BOMBARDELLI, R.A. SYPERRECK, M. A.; SANCHES, E. A. Situação atual e perspectivas para o consumo, processamento e agregação de valor ao pescado. Arquivos de Ciências Veterinárias e Zoologia, v. 8, p. 181-195, 2005
} 
Tabela 6 - Consumo de tilápia no Brasil por faixa de renda

\begin{tabular}{cc}
\hline Faixa de renda & Participação \% \\
\hline$<R \$ 830,00$ & $21 \%$ \\
$R \$ 830,00$ a $1.245,00$ & $18 \%$ \\
$R \$ 1.245,00$ a $2.490,00$ & $36 \%$ \\
$R \$ 2.490,00$ a $4.150,00$ & $11 \%$ \\
$R \$ 4.150,00$ a $R \$ 6.225,00$ & $7 \%$ \\
$R \$ 6.225,00$ a $10.375,00$ & $5 \%$ \\
$>R \$ 10.375,00$ & $2 \%$ \\
\hline
\end{tabular}

Fonte: POF 2008-09 
Tabela 7 - Consumo de tilápia no Brasil, por tipo de produto, por faixa de renda

\begin{tabular}{|c|c|c|c|c|c|c|c|}
\hline $\begin{array}{l}\text { Consumo de tilápia por tipo de } \\
\text { produto / por faixa de renda }\end{array}$ & $<\mathrm{R} \$ \mathbf{8 3 0 , 0 0}$ & $\begin{array}{c}\mathrm{R} \$ 830,00 \mathrm{a} \\
1.245,00 \\
\end{array}$ & $\begin{array}{c}R 1.245,00 \mathrm{a} \\
2.490,00 \\
\end{array}$ & $\begin{array}{c}\mathrm{R} \$ 2.490,00 \mathrm{a} \\
4.150,00 \\
\end{array}$ & $\begin{array}{c}\mathrm{R} \$ 4.150,00 \mathrm{a} \\
6.225,00 \\
\end{array}$ & $\begin{array}{c}\$ 6.225,00 \mathrm{a} \\
10.375,00 \\
\end{array}$ & $>\mathrm{R} \$ \mathbf{1 0 . 3 7 5 , 0 0}$ \\
\hline Peixe inteiro tilápia & $19,40 \%$ & $16,52 \%$ & $31,78 \%$ & $6,05 \%$ & $1,55 \%$ & $3,66 \%$ & $0,04 \%$ \\
\hline Peixe em postas tilápia & $0,39 \%$ & $0,74 \%$ & $1,38 \%$ & $0,00 \%$ & $0,31 \%$ & $0,00 \%$ & $0,00 \%$ \\
\hline Peixe em filé fresco tilápia & $0,48 \%$ & $0,29 \%$ & $0,88 \%$ & $1,77 \%$ & $0,29 \%$ & $0,74 \%$ & $0,15 \%$ \\
\hline Peixe salgado tilápia & $0,00 \%$ & $0,07 \%$ & $0,55 \%$ & $0,00 \%$ & $0,37 \%$ & $0,13 \%$ & $0,00 \%$ \\
\hline Peixe em filé congelado tilápia & $0,42 \%$ & $0,86 \%$ & $1,14 \%$ & $3,01 \%$ & $4,88 \%$ & $0,48 \%$ & $1,68 \%$ \\
\hline
\end{tabular}

Fonte: POF 2008-09 
Os dados da tabela 7 mostram a preferência por tipo de produto de acordo com a faixa de renda. Os brasileiros compraram tilápia inteira em sua maioria $(67,7 \%$ do total) e, isso é também observado no estado de São Paulo até os dias atuais, segundo os dados apresentados pelo varejo para o ano 2014.

Considerando que a produção do estado é em sua totalidade para suprir a demanda local, esta análise mostra que a comercialização de tilápia é em sua maioria inteira e não em filé como apontado por Sussel (2011).

Nesta mesma tabela pode-se ver que filé fresco representou 4,6\% do total de tilápia consumida no Brasil e, filé congelado, 12,47\%, sendo este último consumido principalmente pela população de renda acima de $R \$ 2.490,00$. Essa análise traz as mesmas conclusões das análises feitas com os dados de preço coletados no varejo em 2015: a tilápia é um peixe que atrai tanto a população de menor renda (com o peixe inteiro) quanto a de maior renda (com o filé).

Interessante notar que o filé congelado predominou nas classes com renda entre $R \$$ 4.150 a $R \$ 6.225,00$ e acima de $R \$ 10.375,00$. Porém, foi o peixe inteiro o mais consumido pelas classes com renda entre $R \$ 6.225,00$ e $R \$ 10.375,00$. As pessoas da faixa de renda entre $R \$ 2.490,00$ e $R \$ 4.150,00$ foram as que mais consumiram filé fresco.

Apesar de, na POF, serem apresentados cinco diferentes tipos de produto, na pesquisa a campo realizada para este trabalho encontraram-se apenas três, não sendo observada a presença de postas de tilápia e tilápia salgada.

\subsubsection{Resultado do questionário para consumidores}

O perfil dos consumidores paulistas que responderam à pesquisa realizada exclusivamente para este estudo pode ser visualizado nos gráficos 13 e 14 abaixo. 
Figura 12 - Idade dos participantes da pesquisa com consumidores no estado de São Paulo.

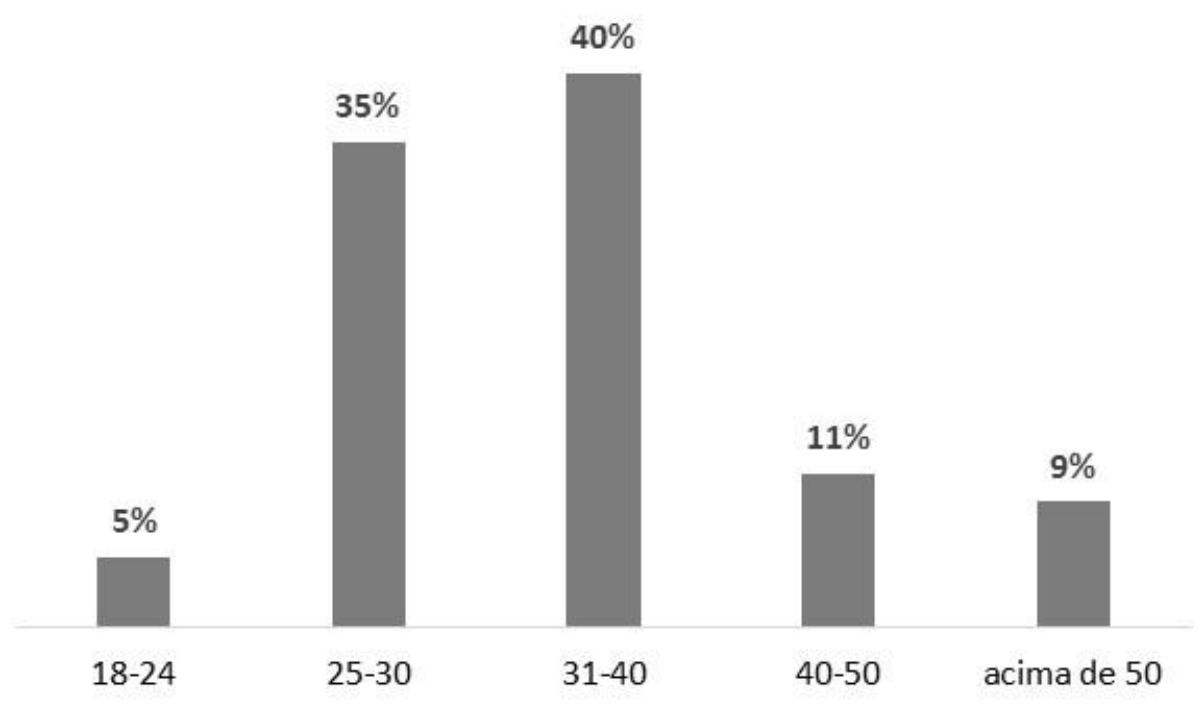

Fonte: da própria autora

Figura 13 - Renda dos participantes da pesquisa com consumidores no estado de São Paulo

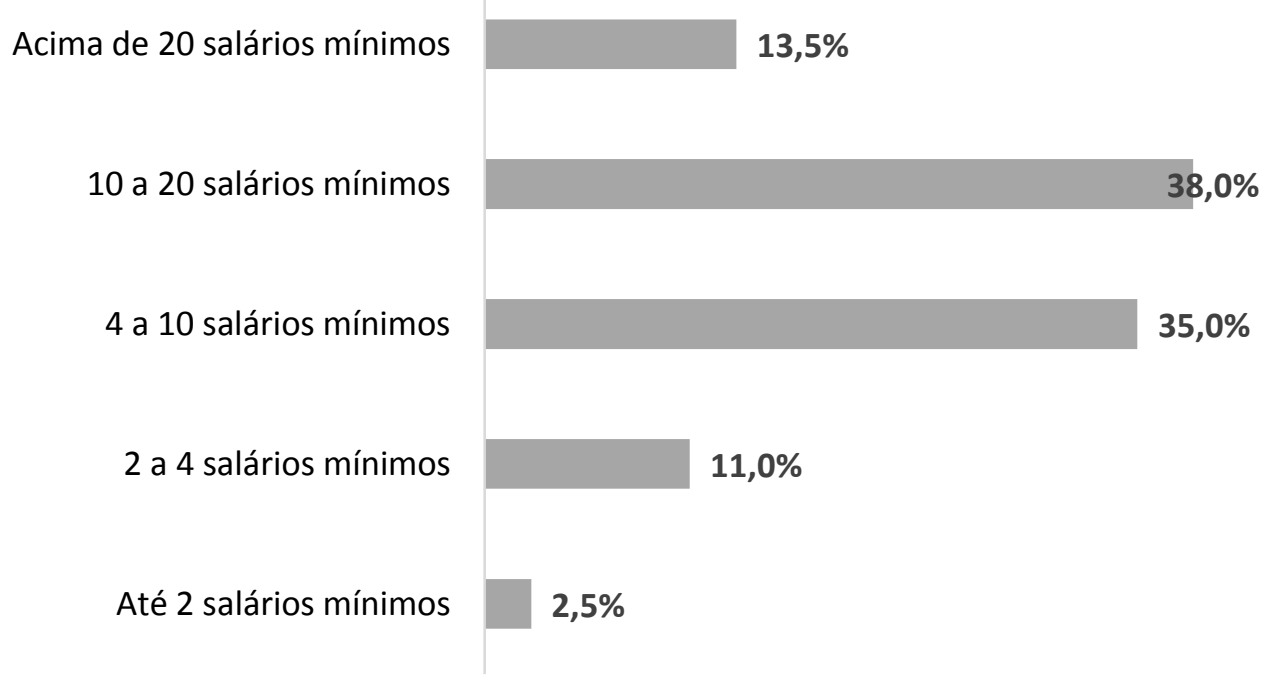

Fonte: da própria autora

Sessenta por cento são moradores de cidades do interior do estado de São Paulo e $40 \%$ de São Paulo capital. $75 \%$ dos que responderam informaram consumir tilápia. 
A carne bovina foi apontada como sendo a proteína mais consumida por $61 \%$ dos participantes da pesquisa para o estudo em questão, seguida da carne de frango (27\%), peixes e frutos do mar $(7 \%)$ e, carne suína (3\%). Em estudo realizado por Tavares (2013) em Belo Horizonte (MG), a carne de peixe foi identificada como a menos consumida na cidade e, a carne bovina, como a mais consumida, seguida pela carne de frango e carne suína.

Quando questionados sobre a proteína que preferem consumir, 40\% responderam que preferem a carne bovina por ter sabor agradável, ser fácil de preparar e ser encontrada com facilidade. Dentre os motivos para a carne vermelha ser citada como a proteína preferida, estão: sabor, praticidade no preparo e facilidade de encontrar no local de compra de alimentos.

$37 \%$ apontaram peixes e frutos do mar como sendo a proteína que preferem consumir, devido ser uma proteína mais saudável e ter bom sabor. Este resultado assemelhouse aos obtidos por KUBITZA (2002) e NETO (2010), nos quais os autores relataram que as principais razões para o consumo de peixe são o prazer em comer carne gostosa e saudável (Tavares, 2013).

Dados de uma pesquisa realizada nos Estados Unidos mostraram que os consumidores americanos faziam compra de alimentos considerando a saúde, conveniência, a preferência das crianças e o preço dos alimentos, respectivamente (PEAVEY, 1994). Quando questionados sobre o peixe, o aspecto nutricional foi o atributo mais importante e, em outros estudos, essa questão foi tratada como sendo um fator motivacional para o consumo de pescado (U. S. Dept. of Commerce, 1991; Egan e Gislason, 1989 apud PEAVEY 1994).

Em pesquisa realizada por Melo (2011) na região do semiárido de Juazeiro (BA) e Petrolina (PE), os consumidores quando questionados sobre os fatores que levariam a aumentar o consumo da carne de peixe, a maioria dos entrevistados $(51,25 \%)$ respondeu que o sabor é o mais importante. Em segundo lugar a questão da saúde, com $33,15 \%$, a qual está relacionada à qualidade nutricional da carne de peixe e, por último, o preço da carne, com $8,70 \%$. 
O mesmo resultado foi encontrado para os consumidores do estado de São Paulo, avaliando-se o consumo de tilápia, que apontaram o sabor suave como o atributo mais importante para o consumo. $\mathrm{O}$ aspecto nutricional foi o segundo mais importante e, outros aspectos citados foram a ausência de espinha e praticidade no preparo, respectivamente, conforme figura 14 .

Figura 14 - Fatores que estimulam o consumo de tilápia

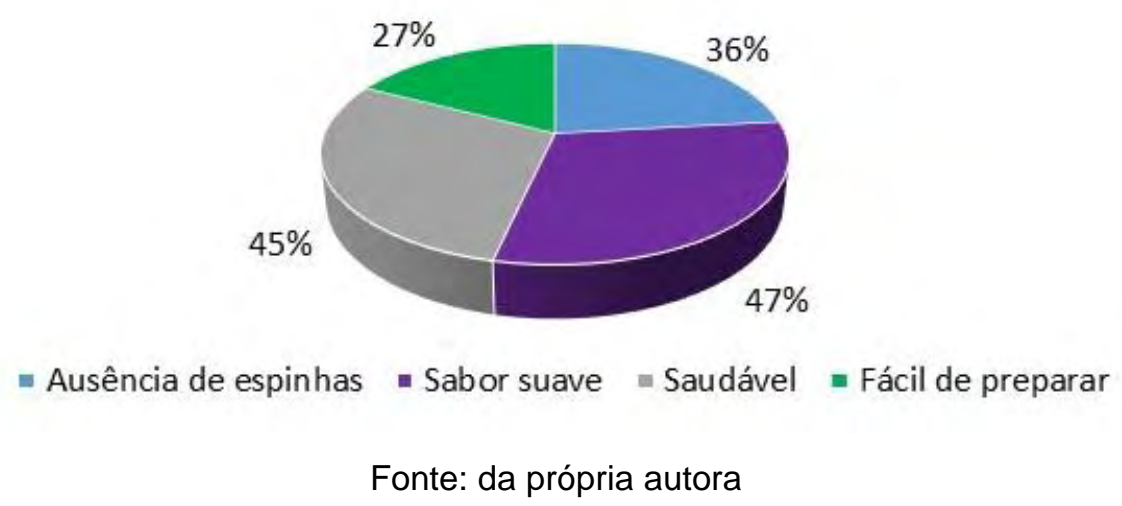

Considerando os aspectos negativos, as espinhas foram mencionadas como o atributo que menos agrada os consumidores em pesquisa nos Estados Unidos (PEAVEY, 1994) e, pode-se dizer que a presença de espinha também é um fator que desagrada os consumidores brasileiros.

Quanto à facilidade no preparo, o mercado consumidor prefere um produto elaborado para facilitar a preparação e consumo do mesmo. Em estudo realizado por Gagleazzi et al. (2002 apud Melo, 2011) ${ }^{5}$, a reduzida frequência de escolha de pescado pelo consumidor se deve principalmente a problemas sanitários e tecnológicos, relacionados à questão de não encontrar os produtos frescos ou com boa aparência no ponto de venda, poucos produtos elaborados, e de difícil preparo.

\footnotetext{
${ }^{5}$ GAGLEAZZI, U. A. et al. Caracterização do consumo de carnes no Brasil. Revista Nacional da Carne, Chapecó, v. 310, p. 152-160, 2002.
} 
O processamento da carne de peixe no Brasil é muito reduzido quando comparado com o de outros animais, principalmente aves (Melo, 2011). De acordo com Ostrensky, Borghetti e Pedini (2000), o processamento fica limitado apenas às formas mais simples e menos elaboradas de transformação como evisceração, filetagem e/ou resfriamento, e/ou congelamento e, isso foi constatado na pesquisa a campo realizada nas quatro principais redes de varejo do estado de São Paulo.

Apesar disso, diversos estudos indicam que muitos consumidores acreditam que os produtos processados, especialmente os congelados, são inferiores, simplesmente porque eles não são frescos (Egan e Gislason, 1989; Pirquet, 1990 apud Peavey, 1994). Este é um dos obstáculos para o sucesso no desenvolvimento de novos produtos no setor de aquicultura e pesca. Entretanto, Melo (2011) sinaliza que o consumo de pescado pode ser estimulado por meio de processamento e industrialização da carne de peixe e também com o marketing. A elaboração de produtos tais como o fishburger, almôndegas, apresuntados, patê, filé in natura, marinados, defumados, picles de peixe, além de outros, propiciam alternativas para o mercado consumidor

Ainda segundo Melo (2011), o sabor da carne de peixe representa uma característica importante e que deveria ser explorada de forma comercial para aumentar o consumo. Os consumidores elegem a carne de peixe pelo aspecto da saúde. O fato da carne de peixe ser um alimento proteico de alto valor biológico para o consumo humano, comparada com outras carnes consumidas (bovina, suína, ovina, caprina, aves e outras), poderia ser mais explorado com intuito de estimular e aumentar o consumo.

A tabela abaixo mostra os tipos de produtos adquiridos pelo consumidor paulista quando compra tilápia: 
Tabela 8 - Tipo de produto adquirido pelo consumidor paulista

\begin{tabular}{cc}
\hline$\%$ & Tipo de produto \\
\hline $46 \%$ & Filé sem pele e congelado \\
$33 \%$ & Filé sem pele e fresco \\
$8 \%$ & Inteira e fresca \\
$6 \%$ & Inteira, eviscerada e fresca \\
$7 \%$ & Outros \\
\hline \multicolumn{2}{c}{ Fonte: da própria autora }
\end{tabular}

Quando analisado o fator preço, este é um indicador que desestimula o consumo (figura 15). Por isso, se faz necessário que o preço da carne de peixe in natura venha competir com o preço da carne de outros animais. Na pesquisa realizada no estado de São Paulo, a alimentação mais balanceada e disponibilidade no ponto de venda foram os dois fatores mais citados pelos entrevistados.

Figura 15 - Fatores que levariam a um maior consumo de tilápia
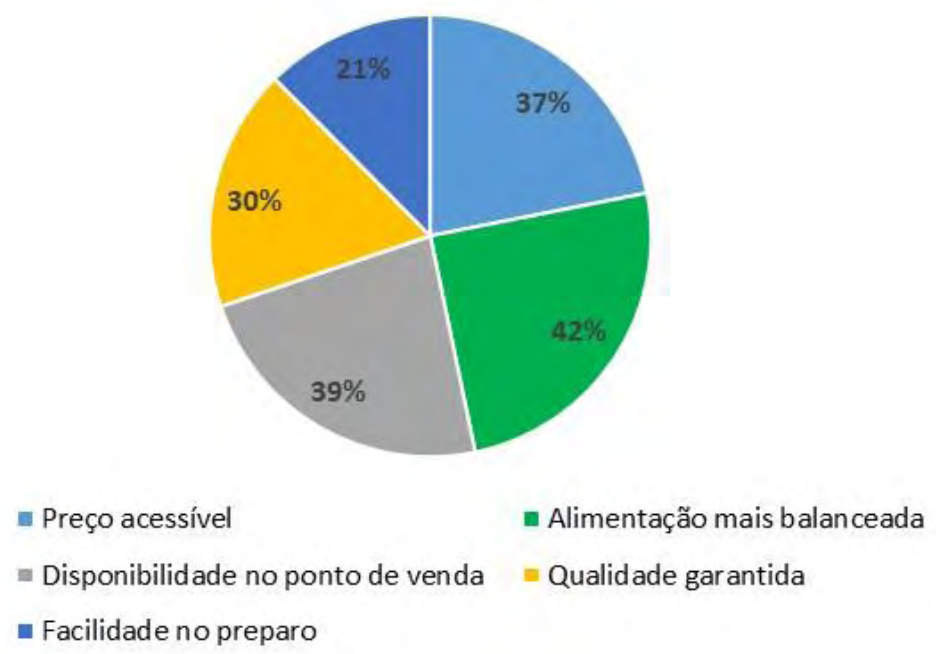

Fonte: da própria autora

Abaixo o valor pago por quilo de tilápia, na última compra realizada pelos consumidores: 
Tabela 9 - Preço do kg de tilápia na última compra realizada por consumidores paulistas

\begin{tabular}{cc}
\hline$\%$ & Valor por kg (R\$) \\
\hline $46 \%$ & não lembro \\
$29 \%$ & $\mathrm{R} \$ 20,00-\mathrm{R} \$ 30,00$ \\
$16 \%$ & $\mathrm{R} \$ 10,00-\mathrm{R} \$ 20,00$ \\
$8 \%$ & $\mathrm{R} \$ 30,00$ ou mais \\
$1 \%$ & $\mathrm{R} \$ 1,00-\mathrm{R} \$ 10,00$ \\
\hline
\end{tabular}

Fonte: da própria autora

O alto preço do peixe em relação a outras opções de proteína foi mencionado em pesquisa norte-americana e, devido aos altos preços, o consumidor tem que escolher não só dentre as espécies que ele prefere, mas dentre àquelas que ele pode pagar (PEAVEY, 1994).

Quanto aos motivos pelos quais os consumidores paulistas não comem mais tilápia, o que mais foi citado - por quase $50 \%$ dos entrevistados - foi a falta do hábito de comprar, seguido por não encontrar o produto no local onde faz compras e, o peixe não ser uma opção nos restaurantes que frequenta (figura 16).

Figura 16 - Motivos que levam o consumidor a não consumir mais tilápia

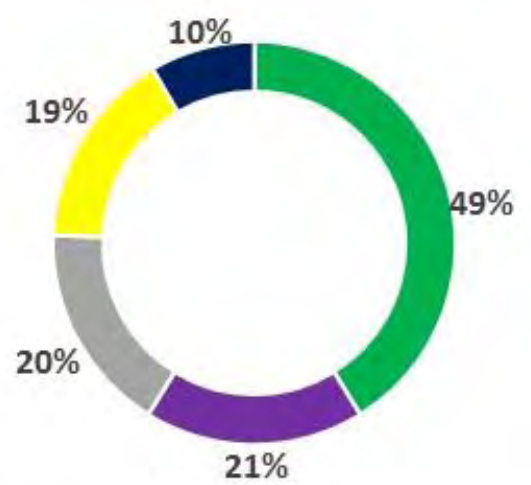

- Não tem o hábito de comprar

- Não encontrar no local em que faz compras

- Não há esta opção no restaurante que frequenta

Preço elevado comparado a outras proteínas anima is

- Acha difícil preparar

Fonte: da própria autora 
Um dos fatores que favoreceria um aumento no consumo de tilápia no estado de São Paulo seria a indústria disponibilizar produtos de mais fácil preparo, mostrando a tendência para os filés de tilápia em comparação ao peixe inteiro. $10 \%$ dos entrevistados apontaram a dificuldade no preparo como um motivo que os levam a não consumir mais tilápia.

De acordo com Souza (2002 apud Melo 2011) ${ }^{6}$, a procura por um alimento de qualidade e de fácil preparo é uma das maiores estratégias de marketing exploradas por indústrias de alimentos. Desta forma, a carne de peixe terá de passar por estas fases da cadeia produtiva para que possa competir no mercado das carnes e estimular o consumo.

Na pesquisa americana, já referenciada anteriormente, metade dos consumidores consideraram o peixe um alimento fácil de preparar. Já a outra metade relatou o oposto, porém, assumindo uma falta de confiança no preparo, ou seja, falta de conhecimento em como preparar bem (PEAVEY, 1994).

Dentre todos os aspectos na hora de comprar pescado, o frescor é a preocupação primordial e, esse atributo é analisado pelos consumidores por meio do odor e aparência. Para estes consumidores, a cor do filé é a marca de frescor (PEAVEY, 1994).

O tamanho do pescado é outra questão importante na hora da compra. Os consumidores nos EUA preferem o filé por ser mais fácil de calcular as porções, além de acreditar que os filés têm menos espinhas, é conveniente por não ter que limpar e tirar pele ou gordura, além de fácil de utilizar em diferentes preparações (PEAVEY, 1994).

Os americanos não gostarem de peixes congelados também tem a ver com a forma de congelamento e como este produto é mantido no supermercado. $O$ peixe congelado pode criar cristais de gelo se descongelado e congelado novamente, pode

${ }^{6}$ SOUZA, L.V. Aquicultura. Revista Panorama da Aquicultura, Laranjeiras, v. 71, n. 1, p. 3-6, 2002. 
ter uma camada de gelo muito grande ao redor do filé diminuindo o rendimento da embalagem), podendo afetar a textura do produto, além de o consumidor não ter certeza do frescor daquele produto embalado e, alguns acreditarem que as melhores partes do pescado não estão congeladas, foram destinadas para outros usos mais nobres, restando no pacote embalado apenas as piores partes do peixe (PEAVEY, 1994).

Interessante notar que alguns consumidores acreditam que o congelamento do pescado causa perda de qualidade e valor nutricional, porém, eles não têm essa mesma crença quando perguntados sobre carne bovina congelada (PEAVEY, 1994).

Quanto às expectativas de consumo, 67\% dos entrevistados em São Paulo disseram pretender comer mais tilápia nos próximos anos e, os fatores que os levariam a consumir mais são: alimentação mais balanceada, disponibilidade nos locais que faz compra de alimentos, preço acessível, qualidade garantida e oferta de produtos mais fáceis de preparar, respectivamente.

Analisando-se a questão da substituição, $65 \%$ disse substituir a tilápia por peixes de outras espécies ou frutos do mar quando não encontra a tilápia no ponto de venda. Dentre as espécies citadas pelos entrevistados como substitutas da tilápia, do mais citado para o menos citado, estão: salmão, pescada, merluza, polaca do alasca, sardinha, panga, bacalhau. Abaixo tabela com dados da substituição de tilápia por outras proteínas.

Tabela 10 - Substituição de tilápia na hora da compra por outras proteínas

\begin{tabular}{cc}
\hline$\%$ & Proteína \\
\hline $65 \%$ & Outro peixe ou fruto do mar \\
$15 \%$ & Carne bovina \\
$13 \%$ & Frango \\
$4 \%$ & Outras \\
$3 \%$ & Carne suína \\
\hline
\end{tabular}

Fonte: da própria autora

A análise de correlação dos preços reais entre as espécies cotadas pelo IPC-Fipe e, o preço da tilápia no atacado, apresentou os seguintes resultados: 
Tabela 11 - Resultados da análise de correlação entre os preços da tilápia e das demais espécies

\begin{tabular}{lc}
\hline Espécie & Coeficiente de correlação \\
\hline Pescada & $-0,13$ \\
Sardinha & 0,11 \\
Cação & $-0,56$ \\
Corvina & 0,09 \\
Camarão & $-0,07$ \\
\hline
\end{tabular}

Fonte: da própria autora

Em geral os coeficientes apresentam baixa correlação com o preço da tilápia, ou seja, isso mostra que dentre essas espécies analisadas, há outros fatores que afetam a substituição entre uma e outra, que não só o preço. Apenas os preços da sardinha e da corvina apresentam correlação positiva com os da tilápia. O coeficiente do cação apresenta moderada correlação, porém, negativa, o que indica que, quando preço do cação aumenta, o preço da tilápia diminui.

Para uma análise mais aprofundada, foi realizada uma regressão linear múltipla, tendo como variável dependente o preço da tilápia e como variáveis explicativas, os preços das outras espécies. Todos os preços foram deflacionados para o mês de dezembro de 2014. Os resultados são apresentados abaixo:

Tabela 12 - Resultados da regressão linear múltipla

\begin{tabular}{lcc}
\hline & $\begin{array}{c}\text { Coeficientes } \\
\text { estimados }\end{array}$ & $\begin{array}{c}\text { Estatística } \\
\text { " } t \text { " }\end{array}$ \\
\hline Intercepto & 6,63 & 4,18 \\
Pescada & 0,00 & 0,00 \\
Sardinha & 0,13 & 1,11 \\
Cação & $-0,34$ & $-6,04$ \\
Corvina & 0,17 & 1,87 \\
Camarão & 0,06 & 1,60 \\
\hline R-quadrado ajustado & $45,7 \%$ & \\
\hline
\end{tabular}

Fonte: da própria autora

Analisando-se o R-quadrado ajustado (45,7\%), pode-se dizer com esta análise que os preços dessas espécies não influenciam muito o preço da tilápia. $O$ único 
parâmetro não-nulo estatisticamente (valor da estatística "t" superior a 1,98, em módulo) foi o do cação, indicando que o preço dessa espécie apresentou efeito significativo sobre o da tilápia, porém, com efeito negativo. Tal resultado alinha-se com o efeito já observado por meio do coeficiente de correlação. Os resultados de tal análise, contudo, muito provavelmente não refletem a realidade. Esta tratou-se apenas de uma tentativa para buscar entender a influência do preço de outras espécies de pescado sobre a tilápia. Análises com uso de séries temporais seriam mais indicadas, porém, devido à falta de dados, não puderam ser realizadas.

\subsection{Preço e fatores que o influenciam}

Os preços são um fator-chave de posicionamento e precisam ser definidos em relação ao mercado-alvo, ao mix de sortimento de produtos e serviços à concorrência (KOTLER, 2006).

Um dos fatores que impacta diretamente o preço da tilápia é o preço da ração, pois trata-se de um insumo importante na produção e pode chegar a $70 \%$ do custo total da produção (Figueiredo Júnior e Valente Júnior, 2008).

\subsubsection{Preço da tilápia no atacado}

Abaixo, o gráfico do preço real, deflacionado para o mês de dezembro de 2014 , para tilápia inteira comercializada no atacado nos últimos quatro anos. 
Figura 17 - Preço real (dez/2014) por kg de tilápia inteira comercializada no atacado de 2011 a 2014

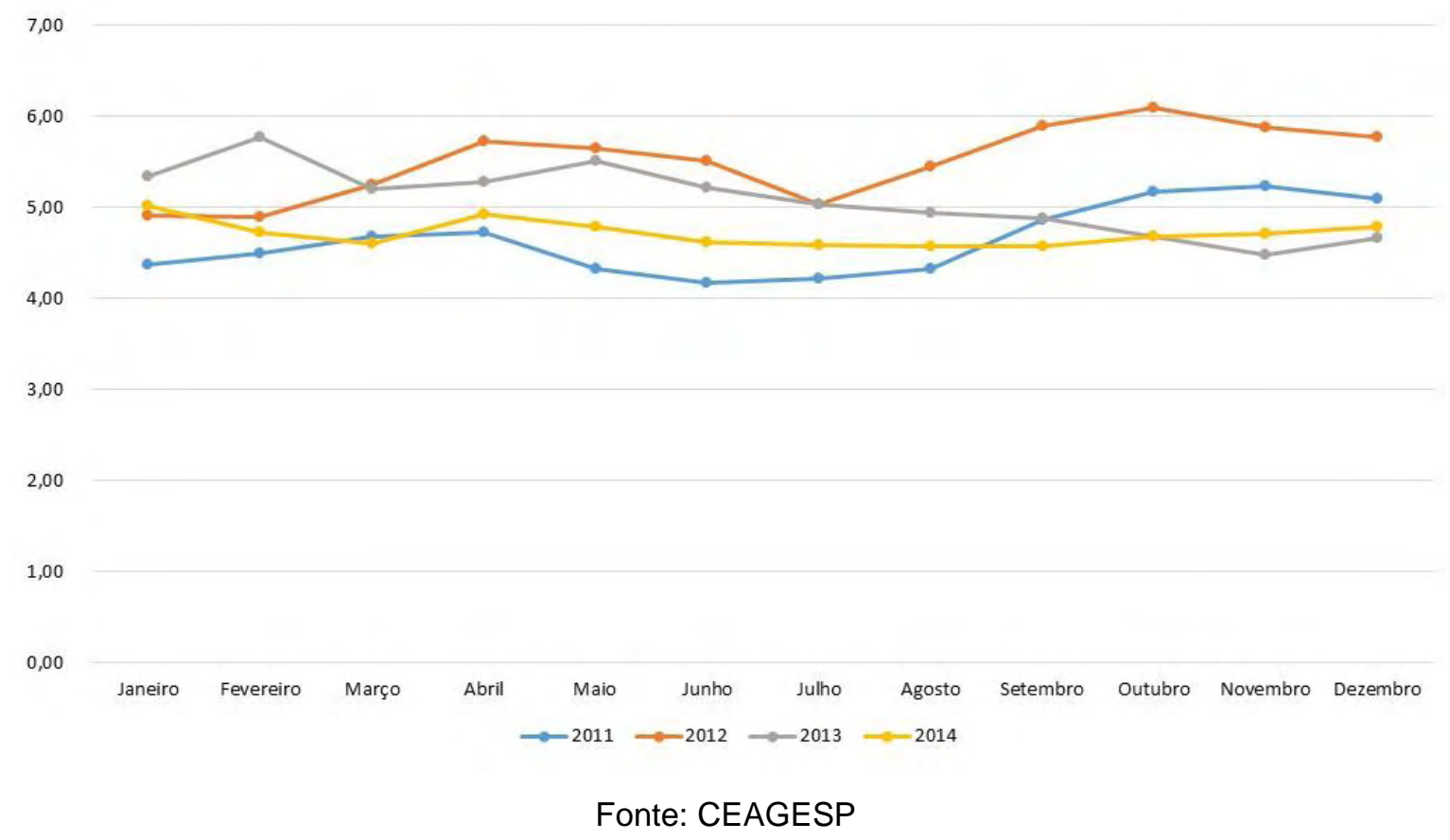

Nota-se que o preço da tilápia em 2014 esteve mais baixo do que em 2012 e 2013. Em 2012 o preço elevou-se a partir de julho, com uma pequena redução em novembro e dezembro, fato contrário ao ocorrido em 2014, em que o preço da tilápia subiu nesses dois meses.

As médias de preço anuais deflacionadas da tilápia no atacado podem ser citadas como sendo: $R \$ 4,64$ em 2011, $R \$ 5,51$ em 2012, $R \$ 5,09$ em 2013 e $R \$ 4,72$ em 2014. De 2011 para 2012 o preço do kg da tilápia inteira aumentou 19\%. Já de 2012 para 2014, o preço reduziu 14\%. Tais fatos podem ser resultantes da variação de volume nesses períodos, conforme figura 9. Quando analisado mês a mês, pode-se dizer que o preço da tilápia no mercado atacadista não oscila muito durante $o$ ano.

Esta questão da oscilação do preço do pescado foi identificada como um dos benefícios para os comerciantes e compradores de peixes de cultivo. Os peixes originados da aquicultura oscilam menos do que os de pesca, devido ao planejamento da produção e, assim, consegue-se programar a compra e fidelizar o cliente. Em 2015, o preço médio mensal no atacado para a tilápia também não variou muito, conforme gráfico abaixo: 
Figura 18 - Preço por kg de tilápia inteira comercializada na CEAGESP de janeiro a abril de 2015

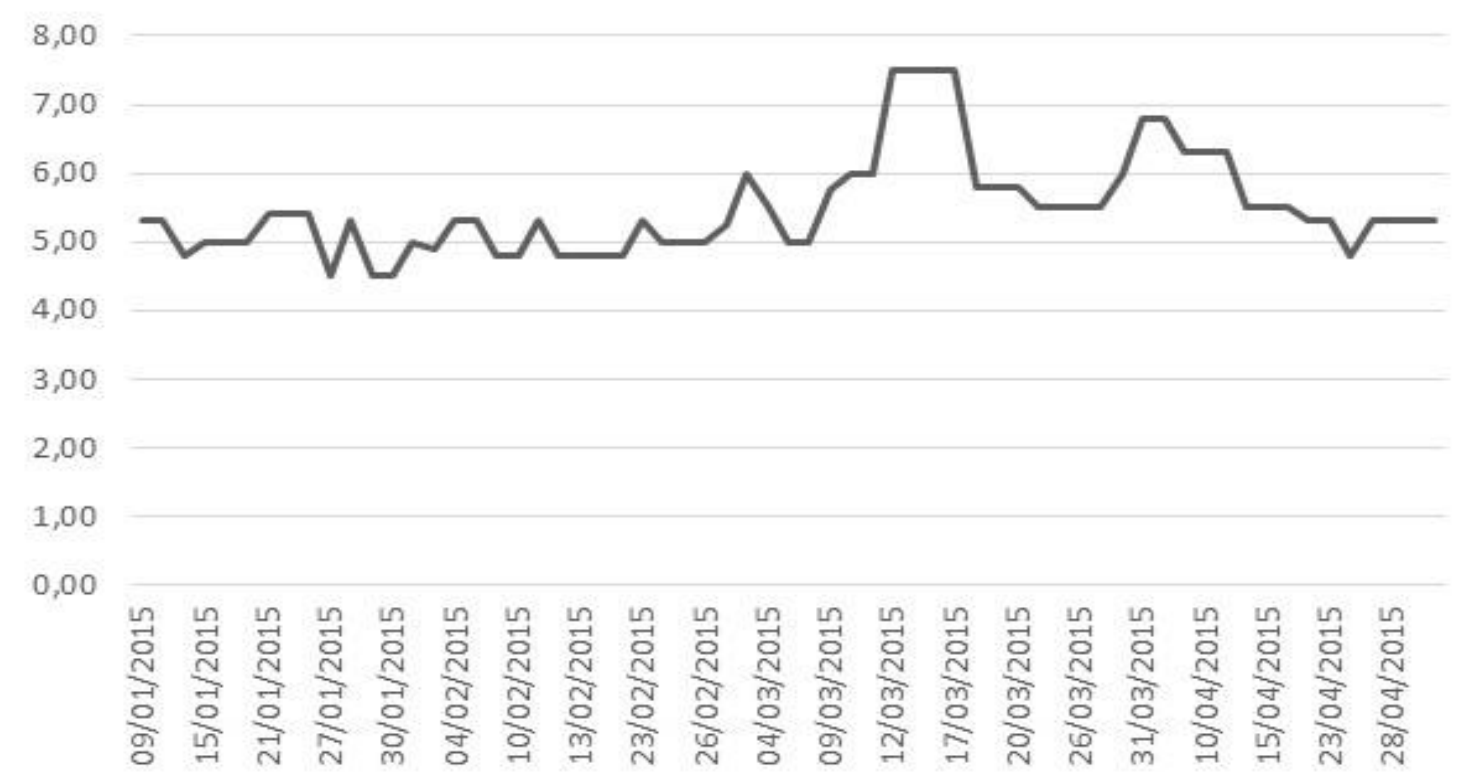

Fonte: CEAGESP

$\mathrm{Na}$ figura acima nota-se claramente o movimento do mercado em aumentar o preço no período que antecede a Páscoa que, em 2015, foi em 05 de abril. Nas primeiras semanas do mês de março, a tilápia saiu de um patamar de $R \$ 5,00 / \mathrm{kg}$ e chegou a $R \$ 7,50 / \mathrm{kg}$, um aumento de $50 \%$. Porém, nota-se que esse preço não se sustentou e, uma semana seguinte, o preço retomou à casa dos $R \$ 5,80 / \mathrm{kg}$.

O preço do filé de tilápia vendido no atacado foi obtido durante visita realizada à CEAGESP, sendo esse entre $R \$ 21,50$ e $R \$ 24,50 / \mathrm{kg}$. O ICMS para o pescado, conforme informado por um comerciante deste mercado é de $8 \%$.

\subsubsection{Preço da tilápia no varejo}

Abaixo um gráfico com o preço da tilápia em filé e inteira comercializada no varejo no período de janeiro a abril de 2015. 
Figura 19 - Preço médio semanal da tilápia no varejo de janeiro a abril de 2015

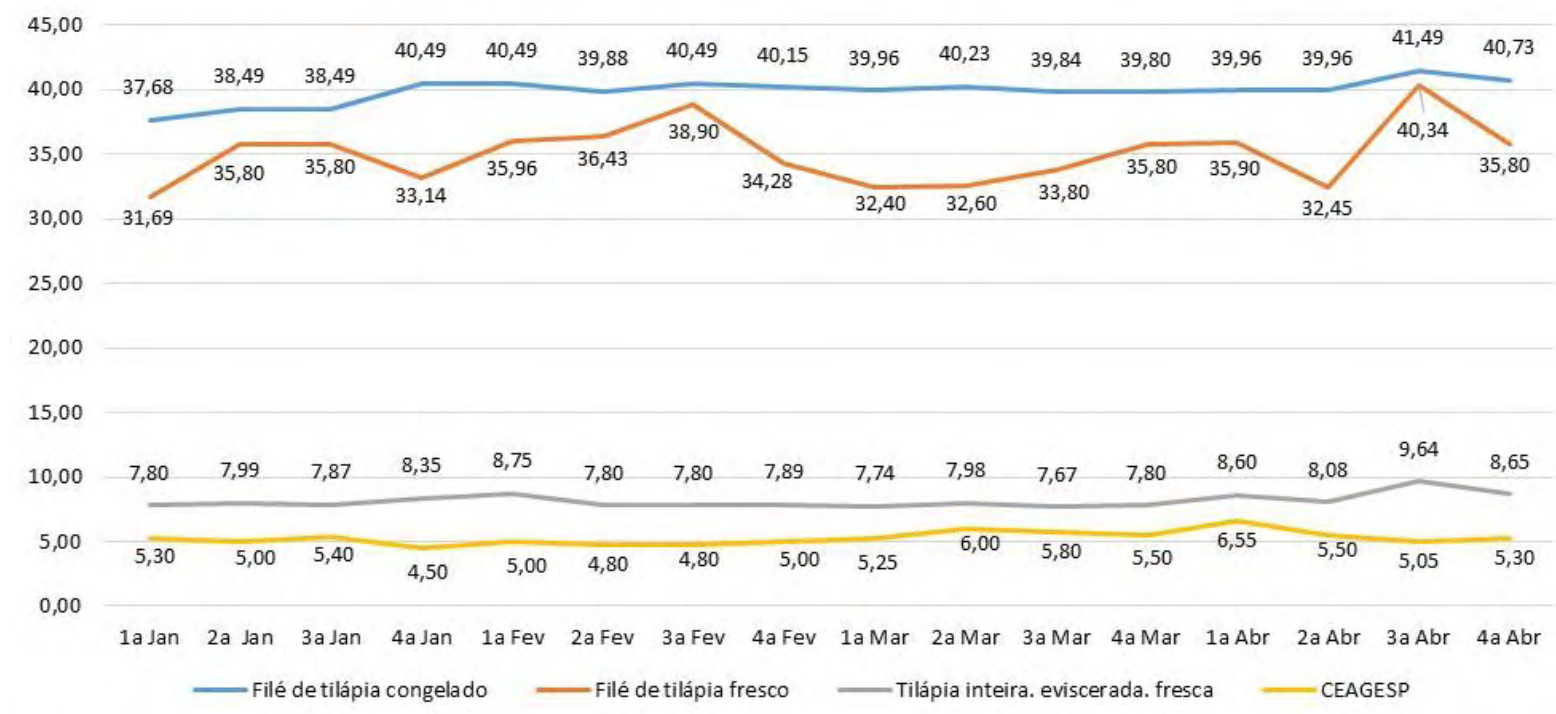

Fonte: da própria autora.

A diferença no preço da tilápia inteira no atacado versus o preço da tilápia inteira e eviscerada comercializada no varejo é de aproximadamente $50 \%$.

Nota-se que o posicionamento do filé de tilápia, seja ele fresco ou congelado, é diferente do peixe inteiro, atingido patamares entre $R \$ 30,00$ e $R \$ 40,00 / \mathrm{kg}$. Um dos motivos para justificar essa questão pode estar no rendimento do pescado que é de aproximadamente $30 \%$ a 33\%. No entanto, analisando-se a questão do rendimento versus o preço e, mantendo-se as margens, o preço da tilápia em filé no ponto de venda equivaleria a $R \$ 25,00$ - $R \$ 28,00$ e, isso não foi observado na maioria das lojas visitadas durante o período da pesquisa.

A tilápia inteira e eviscerada comercializada no varejo tem um dos preços mais baixos quando comparada a outras espécies de peixe também comercializadas inteiras no mesmo ponto de venda. Já o filé, está entre as espécies mais caras, competindo, por exemplo, com o filé de salmão, um peixe tido como nobre. Com este posicionamento de preço, pode-se concluir que o filé de tilápia no varejo fresco ou congelado - está atendendo uma classe social de poder aquisitivo maior do que a tilápia inteira eviscerada, ou seja, uma mesma espécie de peixe, que atinge diferentes classes sociais, com produtos diferentes. 
As espécies de aquicultura conseguem ter uma frequência e regularidade de abastecimento nos pontos de venda de pescado maior e melhor do que os peixes de pesca. Segundo conversa informal com profissionais do setor, esse pode ser tido como um dos benefícios para o consumidor, pois encontra com alta frequência aquela espécie de peixe disponível para compra.

Outra questão que pode ser apontada como favorável aos peixes cultivados é a variação do preço. O preço do peixe de aquicultura sofre menor variação durante o ano do que o peixe de pesca, conforme apresentado na figura 20 abaixo.

Figura 20 - Preço real de espécie de aquicultura x espécie de pesca ao longo do tempo (janeiro a outubro de 2014)

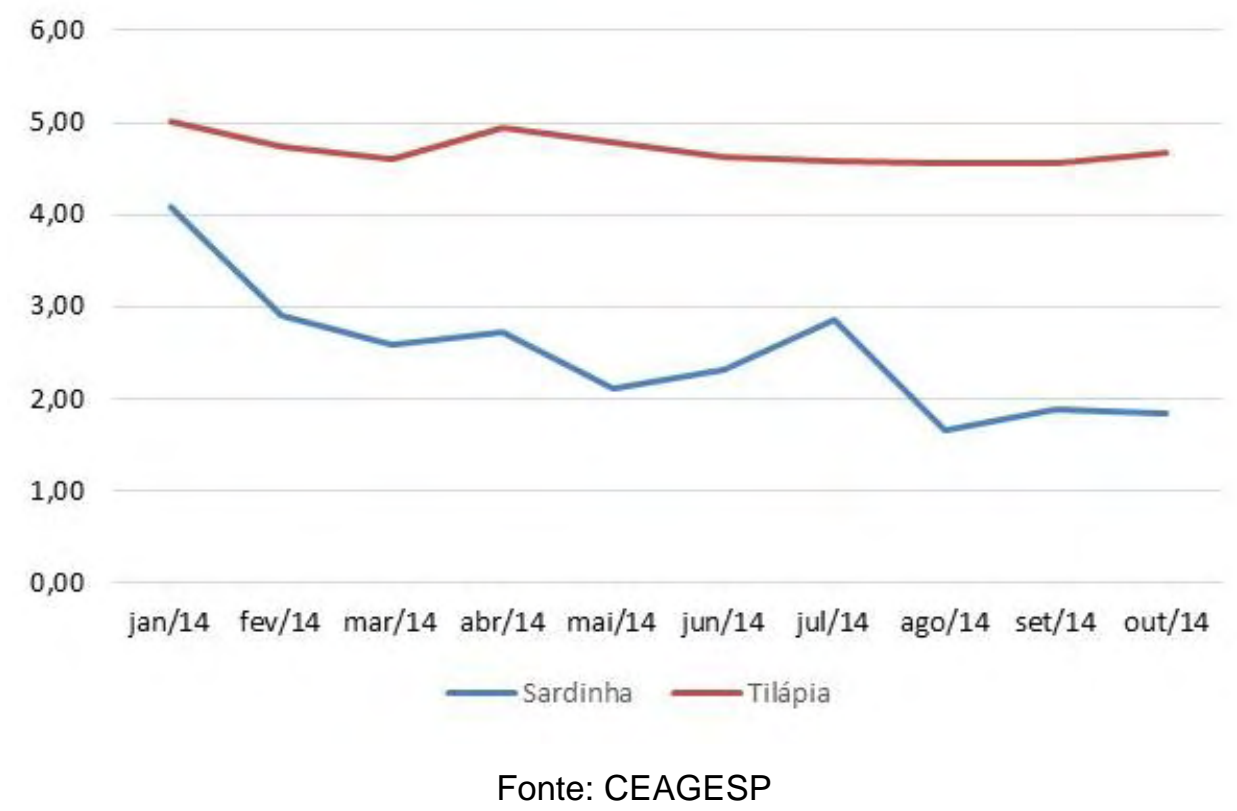

No estudo de Melo (2011) o preço representou o segundo fator que reduz o consumo de peixe, justamente pelo fato que ocorre muita variação no preço ao longo do ano 
em função do extrativismo, o qual é a principal fonte de abastecimento da carne de peixe na região estudada por ele.

Figura 21 - Comportamento dos preços deflacionados médios mensais do filé de tilápia congelado e fresco no varejo na cidade de Piracicaba/SP

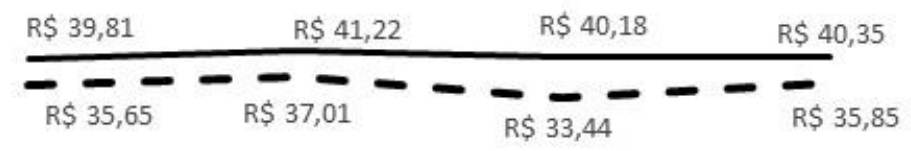

jan/15 fev/15 mar/15 abr/15

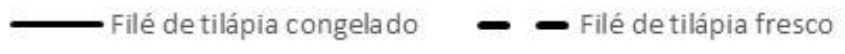

Fonte: da própria autora

O preço do filé de tilápia fresco varia mais durante a semana do que o congelado, devido às promoções e o giro que deve ser forçado devido ao prazo de validade menor do produto, segundo informado pelos varejistas. Essa pode ser uma das razões para o levantamento a campo mostrar o filé fresco com preço abaixo do filé congelado. Com essas variações durante a semana, visa-se uma menor quebra na peixaria, que é atualmente em torno de $2 \%$ a $3 \%$ segundo profissionais do setor. Já o preço do filé congelado mantém-se mais constante por ter um prazo de validade maior.

O filé congelado, por ser de mais fácil manipulação e conservação nas lojas varejistas, é comprado em maiores volumes e, com isso, adquirido a preços melhores. Segundo os varejistas, o filé fresco tem preço mais elevado devido ao custo de operação, envolvendo logística, funcionários, energia, água, construção e equipamentos. Isso impacta diretamente nas margens do varejista, que tem aproximadamente $60 \%$ de margem no filé de tilápia congelado enquanto obtém uma margem média de $40 \%$ no filé de tilápia fresco ${ }^{7}$. Apesar desta informação sobre o preço mais elevado do filé fresco, nas pesquisas a campo realizadas durante quatro meses na cidade de Piracicaba, isso não foi observado (figura 19).

\footnotetext{
${ }^{7}$ Margens médias declaradas por alguns varejistas durante as entrevistas
} 
Os supermercados entrevistados informaram não conhecerem o nível de substitutibilidade entre a tilápia e o salmão, porém, durante as pesquisas a campo verificou-se que o filé de tilápia fresco e o do salmão foram colocados lado a lado em todas as peixarias visitadas. Além disso, o preço do quilo dos dois filés é aproximado em algumas lojas e, segundo a pesquisa realizada para este estudo, o salmão foi o mais apontado como sendo o peixe que o consumidor compraria caso não encontrasse a tilápia à venda.

\subsection{Exportação}

A tilápia é produzida e comercializada em toda a América Latina, exceto em algumas ilhas caribenhas e no Chile. O mercado local para tilápia cresceu muito rápido em diversos países, e no México, mais recentemente. Os Estados Unidos (EUA) são o principal destino da tilápia produzida nesta região, de acordo com Zimmermann (2010).

As importações de tilápia pelos Estados Unidos têm crescido de forma constante ao longo das últimas décadas. Isso se deve à população que se tornou mais familiarizada com $\mathrm{o}$ produto e a espécie que se adaptou às preferências culinárias norteamericanas. Assim como a indústria da tilápia global cresceu, o número de produtos ofertados também aumentou. Atualmente encontram-se no mercado americano, filés frescos ou congelados em diferentes tamanhos e embalagens, com pele ou sem pele, congelados individualmente, defumados e próprios para sashimi. Além destes, subprodutos interessantes surgiram tais como, artigos de couro para vestuário e acessórios, gelatina a partir de peles e ornamentos florais feitos com escamas de peixes secos e coloridos (GLOBEFISH, 2015).

O mercado de importação de tilápia pelos Estados Unidos está dividido em fresco e congelado. $\mathrm{O}$ volume de filé congelado continua crescendo fortemente, enquanto que o produto inteiro congelado permaneceu praticamente constante devido a um mercado limitado. Em 2011, os fornecedores primários de filés congelados para os Estados Unidos eram a China (US\$ 522 milhões) e Indonésia (US\$ 60 milhões). China (US\$ 50 milhões) e Taiwan (US\$26 milhões) foram responsáveis por quase todas as 
importações de peixe inteiro congelado pelo país norte-americano. Quando há declínio de produção nesses países, isso ocorre devido a temperaturas atípicas frias do inverno ou problemas com surtos de doenças e, nesses casos, o abastecimento de produtos congelados para os mercados norte-americanos é reduzido, e os preços geralmente aumentam de acordo (GLOBEFISH, 2015).

O setor de filé fresco, dominado por países latino-americanos, ainda está experimentando um crescimento na demanda, especialmente pelos restaurantes e supermercados. Em 2010, Honduras superou o Equador como o principal fornecedor de filés de tilápia frescos aos EUA. Em 2011, os principais fornecedores de filés de tilápia frescos para o mercado norte-americano foram Honduras (US\$ 62 milhões), Equador (US\$ 50 milhões) e Colômbia (US\$ 18 milhões) (GLOBEFISH, 2015).

A popularidade de tilápia nos Estados Unidos manteve-se inalterada durante a recessão econômica no país em 2008, embora o consumo global de pescado tenha caído 1,3\% em 2009. Para a tilápia, no entanto, o consumo aumentou ligeiramente nesse período. Como controles de qualidade (off-flavour) tornaram-se mais rigorosos nos principais países exportadores, a participação da tilápia provavelmente deverá aumentar naquele país. A tilápia está se tornando cada vez mais popular também em outros países europeus, e uma parte da oferta tradicionalmente destinada ao Estados Unidos pode ser direcionada no futuro para a Europa e outros mercados (GLOBEFISH, 2015).

Segundo dados da Aliceweb, o Brasil não teria exportado tilápia para os Estados Unidos entre os anos 2000 e 2011, porém, constatou-se que houve alteração na nomenclatura da espécie e, por isso, os dados não apareceram para a pesquisa realizada seguindo os novos códigos para a espécie. Contudo, é possível analisar os dados de exportação de tilápia nesses anos, segundo um relatório do USDA (United States Department of Agriculture). Por meio dele, observa-se que o Brasil iniciou exportação em 2000, porém com volumes pequenos, segundo tabela 10. 
Tabela 13 - Histórico de importação de tilápia pelos Estados Unidos (em t)

\begin{tabular}{|c|c|c|c|c|c|c|c|c|c|c|c|c|c|c|c|c|c|}
\hline & 2000 & 2001 & 2002 & 2003 & 2004 & 2005 & 2006 & 2007 & 2008 & 2009 & 2010 & 2011 & 2012 & 2013 & 2014 & Soma & $\%$ \\
\hline $\begin{array}{l}\text { China } \\
\text { (Mainland) }\end{array}$ & 13.492 & 13.590 & 26.486 & 45.480 & 59.932 & 75.037 & 103.814 & 120.151 & 119.253 & 130.420 & 158.521 & 144.378 & 173.398 & 168.283 & 172.664 & 1.524 .900 & $66,8 \%$ \\
\hline $\begin{array}{l}\text { China } \\
\text { (Taiwan) }\end{array}$ & 17.722 & 29.829 & 23.647 & 22.415 & 27.708 & 27.266 & 21.341 & 16.100 & 18.533 & 15.720 & 18.765 & 13.919 & 12.655 & 18.549 & 13.685 & 297.853 & $13,1 \%$ \\
\hline Equador & 3.447 & 5.190 & 6.876 & 9.727 & 10.412 & 10.932 & 11.119 & 12.390 & 9.149 & 10.178 & 8.497 & 8.159 & 8.381 & 5.667 & 2.519 & 122.643 & $5,4 \%$ \\
\hline Indonésia & 1.221 & 2.218 & 2.575 & 3.588 & 4.253 & 6.638 & 7.392 & 8.646 & 9.793 & 8.769 & 10.224 & 9.227 & 11.967 & 11.828 & 11.608 & 109.947 & $4,8 \%$ \\
\hline Honduras & 1.046 & 1.437 & 2.879 & 2.851 & 4.042 & 6.572 & 7.252 & 8.589 & 8.491 & 7.116 & 7.354 & 8.133 & 7.992 & 8.263 & 10.331 & 92.348 & $4,0 \%$ \\
\hline $\begin{array}{l}\text { Costa } \\
\text { Rica }\end{array}$ & 2.684 & 3.109 & 3.208 & 4.000 & 4.107 & 3.849 & 2.678 & 4.984 & 5.576 & 5.817 & 5.978 & 5.420 & 5.704 & 6.792 & 5.455 & 69.360 & $3,0 \%$ \\
\hline Tailândia & 198 & 260 & 617 & 1.068 & 878 & 1.032 & 786 & 183 & 3.790 & 1.601 & 2.241 & 1.888 & 2.945 & 1.933 & 2.455 & 21.874 & $1,0 \%$ \\
\hline Colômbia & 29 & 32 & 12 & 3 & 1 & 173 & 570 & 742 & 1.695 & 1.725 & 1.845 & 2.387 & 2.904 & 3.877 & 4.141 & 20.135 & $0,9 \%$ \\
\hline Panamá & 161 & 353 & 345 & 241 & 289 & 721 & 720 & 382 & 684 & 340 & 356 & 268 & 443 & 738 & 282 & 6.321 & $0,3 \%$ \\
\hline Vietnã & 80 & 60 & 109 & 132 & 43 & 925 & 325 & 144 & 223 & 288 & 337 & 314 & 347 & 215 & 2.459 & 6.000 & $0,3 \%$ \\
\hline México & 0 & 0 & 0 & 0 & 0 & 0 & 12 & 2 & 0 & 0 & 0 & 118 & 6 & 1.611 & 4.057 & 5.806 & $0,3 \%$ \\
\hline Brasil & 2 & 8 & 161 & 235 & 323 & 973 & 1.042 & 229 & 511 & 264 & 332 & 73 & 11 & 67 & 56 & 4.288 & $0,2 \%$ \\
\hline Total & 40.081 & 56.084 & 66.914 & 89.739 & 111.986 & 134.119 & 157.051 & 172.541 & 177.697 & 182.239 & 214.450 & 194.283 & 226.754 & 227.824 & 229.713 & 2.281 .475 & $100,0 \%$ \\
\hline
\end{tabular}

Fonte: USDA, 2015 
Os países que abastecem o mercado americano com tal espécie ficam localizados na Ásia, América Central e Sul (NORMAN-LÓPEZ; BJøRNDAL, 2009). As exportações brasileiras de tilápia para os Estados Unidos foram aumentando ano a ano desde a abertura desse mercado. Porém, nos últimos quatro anos a exportação média foi de 52 toneladas anuais. $O$ total em valor de tilápia importado pelo mercado americano em 2013 foi mais de US\$1 bilhão - 7\% a mais do que em 2012 (GLOBEFISH, 2015).

Das 229 mil toneladas de tilápia importadas pelos Estados Unidos em 2014, 72\% foi na forma de filé congelado (principalmente da China), 17\% inteira e congelada e, 11\% de filé refrigerado, sendo Honduras, Costa Rica, Colômbia e México os principais exportadores, tendo, os dois últimos, aumentado a participação em filés frescos em $6 \%$ e $49 \%$ respectivamente, de um ano para o outro (USDA, 2015). O Brasil tem potencial de atender o mercado americano com filé refrigerado devido sua proximidade logística. Tanto é que, as exportações realizadas pelo Brasil ao país da América do Norte foram apenas de filé fresco, conforme tabela 11. 
Tabela 14 - Exportação de tilápia do Brasil para os Estados Unidos, por produto, por ano, em t

\begin{tabular}{|c|c|c|c|c|c|c|c|c|c|c|c|c|c|c|c|}
\hline Brasil & 2000 & 2001 & 2002 & 2003 & 2004 & 2005 & 2006 & 2007 & 2008 & 2009 & 2010 & 2011 & 2012 & 2013 & 2014 \\
\hline $\begin{array}{l}\text { Inteira e } \\
\text { Congelada }\end{array}$ & 0,0 & 0,0 & 0,0 & 0,0 & 0,0 & 8,3 & 30,6 & 0,0 & 0,0 & 0,0 & 0,0 & 0,0 & 0,0 & 0,0 & 0,0 \\
\hline Filé Congelado & 1,8 & 0,0 & 111,8 & 208,3 & 323,1 & 962,6 & 1011,8 & 219,5 & 509,1 & 264,2 & 332,5 & 73,5 & 11,0 & 67,4 & 56,2 \\
\hline Filé Fresco & 0,0 & 8,0 & 49,0 & 26,9 & 0,0 & 1,7 & 0,0 & 9,1 & 1,8 & 0,0 & 0,0 & 0,0 & 0,0 & 0,0 & 0,0 \\
\hline Total & 0,0 & 0,0 & 0,0 & 0,0 & 0,0 & 0,0 & 0,0 & 0,0 & 0,0 & 0,0 & 0,0 & 0,0 & 0,0 & 0,0 & 0,0 \\
\hline
\end{tabular}

Fonte: USDA, 2015 
Deve-se ressaltar que a produção brasileira de pescado ainda não é suficiente para atender a demanda interna. De acordo com dados do Ministério do Desenvolvimento, em 2012 o déficit da balança comercial de pescado foi de US\$1 bilhão. Apesar de Sussel (2013) afirmar que toda a tilápia produzida fica no mercado interno, nota-se, ainda que pequeno, um volume de filé fresco exportado aos Estados Unidos.

Unindo-se as projeções da FAO para 2030 às perspectivas do Rabobank - de o Brasil fornecer 1 milhão de toneladas de tilápia para o mercado externo - e, às previsões de aumento da demanda pela espécie nos EUA e Europa, têm-se um cenário que representa um bom indicador da demanda internacional.

Para usufruir dessa oportunidade, a indústria paulista da tilápia pode, assim como outras cadeias de pescado fizeram, planejar sua produção e focar em um mercado específico, como é o caso da indústria europeia de salmão e truta salmonada para atender o Japão. Essas espécies atendem o mercado japonês por terem carne vermelha. Até 1994, o market share dessas espécies no país era de 14\% para a truta salmonada, $11 \%$ para o salmão (coho) de cultivo e $8 \%$ para o salmão (coho) capturado. Em 2000, essas espécies já apresentavam participações muito mais significativas nesse mercado: 32\%, 37\% e 1\% respectivamente (Asche et al., 2005), o que mostra também a importância que ganhou o mercado de peixe cultivado naquele país.

Contudo, para o Brasil tornar-se um país exportador de tilápia, é preciso que seu produto tenha qualidade, regularidade, cadeia de frio e certificações para atender, satisfazer e fidelizar os clientes internacionais.

5.6 Oportunidades de melhoria na comercialização de tilápia

Segundo Bertolini (2004, apud Schlickmann, 2008), os diversos segmentos agroindustriais vêm se transformando de forma significativa nas últimas décadas. Devido ao mercado mais competitivo, as exigências à modernização fazem com que as empresas se voltem para a busca pelo aumento da produção e agregação 
de valor a produtos. Nesse sentido, abrem-se possibilidades de estas empresas interagirem através da coordenação das etapas produtivas (Pereira, 2010).

Uma coordenação mais eficiente, para Schlickmann (2008), poderá também proporcionar vantagens, uma vez que a integração entre as empresas permite um fluxo de informações que podem agregar valor ao produto, adequando-se aos padrões de competitividade. Consequentemente, a proximidade entre os agentes pode resultar em diminuição do custo de transação, o que pode resultar em vantagem competitiva (FROTA, 2006).

Um ponto importante observado durante este trabalho que pode ser apontado como uma oportunidade de melhoria é a questão dos custos de produção do filé da tilápia. Uma vez observado aumento do consumo de salmão no mercado brasileiro, especialmente pelo paulista e, considerando que o consumidor deste estado indicou em pesquisa substituir tilápia por salmão, têm-se aí uma oportunidade identificada.

Interessante, contudo, é que se trata de um produto nacional (tilápia) concorrendo com um produto importado (salmão) e, quando analisado o preço de venda para o varejo (ou seja, o custo para o varejo adquirir o produto) de ambas as espécies, é curioso notar que, analisando-se as médias para o ano de 2014, o custo do filé congelado de salmão para as redes varejistas foi mais baixo do que o do filé de tilápia congelado e, o filé de tilápia fresco, ficou pouco abaixo do filé fresco de salmão.

Tabela 15 - Análise do preço de aquisição do salmão e da tilápia pelo varejo em 2014.

\begin{tabular}{|l|cr|cr|}
\hline & \multicolumn{2}{|c|}{ Preço kg salmão } & \multicolumn{2}{c|}{ Preço kg tilápia } \\
\hline Filé Congelado & $\mathrm{R} \$$ & 17,89 & $\mathrm{R} \$$ & 20,05 \\
\hline Filé Fresco & $\mathrm{R} \$$ & 23,63 & $\mathrm{R} \$$ & 22,80 \\
\hline Inteiro & $\mathrm{R} \$$ & 16,17 & $\mathrm{R} \$$ & 6,58 \\
\hline
\end{tabular}

Fontes: Aliceweb e especialistas do mercado. Dados gerados pela autora

Isso é um dos fatores que causam um posicionamento parecido dos dois peixes na gôndola para o consumidor final. E, conforme literatura internacional, salmão é tido como um peixe de alto valor agregado e, a tilápia, de baixo valor agregado. 
Conclui-se então que há oportunidades de melhoria na produção e processamento da tilápia no mercado brasileiro, de forma que este peixe concorra no mercado nacional com outras espécies de baixo valor agregado.

Uma produção focada para o mercado externo poderia favorecer uma maior oferta de tilápia no mercado interno, reduzir o preço por quilo, aumentar a rentabilidade dos produtores - especialmente nos momentos em que o câmbio é favorável para este tipo de comercialização - tornando, acima de tudo, a tilápia uma commodity de importância econômica para o país, assim como outras no Brasil.

Outra oportunidade está na utilização dos subprodutos da indústria de forma que isso ajude na composição do rendimento do produtor, diminuindo a importância no filé e, rentabilizando via outras partes que podem ser aproveitadas do peixe, principalmente devido ao alto valor nutricional.

Do ponto de vista do consumidor paulista, uma vez identificado que a maioria não tem o hábito de comprar tilápia, dispor o peixe próximo à carne bovina e de frango, que foram apontadas como as mais consumidas por estes consumidores, poderia favorecer com que o paulista lembrasse e considerasse o pescado na hora da compra de alimentos.

Além disso, a oferta de produtos em mais pontos de venda, uma campanha para aumento do consumo médio semanal e, produtos convenientes com preço acessível, poderiam atingir um maior número de consumidores.

Este estudo possibilitou o levantamento de informações recentes sobre o mercado de tilápia e, além disso, com os dados obtidos, foi possível analisar os pontos fortes e fracos dessa cadeia agroindustrial. A não contribuição de alguns agentes da cadeia prejudicou a identificação de alguns pontos importantes para o atingimento de um relato mais completo sobre a tilapicultura paulista. Este fato é reflexo de um setor ainda muito fechado e não colaborativo com a pesquisa. A falta de dados sobre o setor, criticada por muitos, também é resultado desse comportamento e visão de muitos agentes desse setor. 
Para isso, trabalhos mais focados em mercado e, em uma única espécie, se fazem necessários para a identificação das oportunidades e gargalos no desenvolvimento das cadeias produtivas de pescado no Brasil sendo este, uma contribuição adicional às pesquisas já realizadas.

\section{Conclusões}

O foco em desenvolver políticas e estratégias para uma única espécie de peixe, no caso a tilápia, parece ser a melhor forma para se atingir os resultados pretendidos para a tilapicultura brasileira. Essa forma de atuação já é praticada em outros países como Chile (grande produtor de salmão) e Noruega (grande produtor de bacalhau). Nota-se que a competitividade destes países no cenário internacional não se dá por serem grandes produtores de diferentes espécies de pescado, mas apenas uma, bem estruturada, ou seja, uma espécie que é uma commodity de valor e importância econômica para o país.

O consumidor do estado de São Paulo considera o pescado uma proteína animal saudável, a tilápia como uma boa opção dentre as espécies por não ter espinha e ter sabor suave, porém, a média de consumo é de menos de $100 \mathrm{~g}$ por semana. As causas desse baixo consumo podem ser resumidas em o consumidor não ter o hábito de comprar tilápia, o preço ser mais elevado do que outras proteínas animais, o consumidor buscar por produtos de mais fácil preparo e, muitos ainda terem dificuldade de encontrar o produto nos locais em fazem compras de alimentos.

O aumento de investimentos no setor visando aproveitamento integral do pescado e redução do custo de produção, uma maior produção para atender a demanda do mercado nacional e internacional, melhor distribuição e disponibilidade do produto no ponto de venda, redução no preço do produto final e oferta de produtos processados - visando a praticidade no preparo - são algumas das oportunidades identificadas por meio deste estudo.

Aumento do investimento na produção em escala e com tecnologia, para atender um mercado externo crescente e exigente, é uma outra oportunidade aos produtores já 
participantes dessa cadeia e a novos entrantes. Contudo, a questão da regularidade de volume, qualidade, segurança alimentar e certificações são requisitos indispensáveis a esses fornecedores.

O estado de São Paulo tem potencial para se tornar o maior estado brasileiro produtor de tilápia, desde que regulamentações e licenças sejam menos burocratizadas, que os impostos incidentes sobre a ração sejam reduzidos ou abatidos, que o produtor invista mais em tecnologia de produção e processamento, que mais estudos sobre consumo e demandas sejam realizados e, finalmente, que a logística seja feita de forma que a qualidade da tilápia seja mantida do produtor ao varejo e, consiga atingir um número maior de consumidores com preço competitivo.

Finalmente, a geração de dados estatísticos com maior periodicidade e confiáveis é um dos maiores gargalos para que as pesquisas e as análises de viabilidade e investimento em negócios de tilápia sejam possíveis de serem realizados, permitindo projeções mais plausíveis e dando mais segurança aos produtores, empresários e investidores.

Esta questão já foi constatada por outros pesquisadores e reforçada com a realização desta pesquisa. Diante dos fundamentos obtidos pode-se concluir que os dados disponíveis não refletem necessariamente a realidade apresentada pelos especialistas e profissionais do setor. Os motivos para esta questão podem ser diversos, mas um dos que se pode destacar, é a falta de periodicidade e confiabilidade no levantamento e disponibilização de dados de preço, produção e consumo. 


\section{APÊNDICE}

\section{APÊNDICE I - Questionário - Supermercado/Varejo}

Nome completo:

\section{Empresa:}

Cargo:

Dados para contato:

1- Qual o volume de pescado vendido anualmente por esta rede?

2 - Qual o atual volume de tilápia comercializado no ano?

3 - Quais são os produtos com os quais você trabalha (compra e vende):

Tilápia inteira - volume: // \% do total comercializado:

Tilápia inteira e eviscerada - volume: // \% do total comercializado:

$\square$ Filé de tilápia fresco - volume: $/ / \%$ do total comercializado:

$\square$ Filé de tilápia congelado - volume: // \% do total comercializado:

$\square$ Outro-especificar: // volume: // \% do total comercializado:

4 - Aonde do estado vocês mais vendem tilápia? Sabe dizer o motivo?

5 - Quem são os seus fornecedores? Onde estão localizados e quanto paga a eles?

6 - Por quanto vende cada um desses produtos?

7 - Quais são os fatores que influenciam o preço da tilápia?

8 - Como foi a evolução das vendas desses produtos desde 2003 ?

9 - Há meses em que a tilápia é mais ofertada? Se sim, quais?

10 - Há meses em que a tilápia é mais demandada? Se sim, quais?

11 - Quantas lojas que comercializam pescado vocês têm no Estado de SP? Todas vendem tilápia? Quantas dessas têm peixaria (peixe fresco)?

12 - Qual é o percentual de quebra de tilápia?

13 - Já aconteceu de faltar tilápia em alguma das suas lojas? Quando e por quê?

14 - O que você gostaria que melhorasse no fornecimento de tilápia a vocês? O volume fornecido hoje atende a sua demanda? 
15 - O que você espera das vendas de tilápia nos próximos 5 anos? Você espera aumentar a compra de tilápia para oferecer aos clientes?

16 - A peixaria é um negócio rentável para vocês? É melhor vender peixe congelado ou peixe fresco? Qual vende mais?

17 - A precificação do pescado é feita maneira igual a todas as espécies com as quais vocês trabalham? Se não, qual é a forma de precificação da tilápia?

18 - Quais são as tecnologias empregadas no seu negócio para a conservação e exposição do pescado nas lojas?

19 - Você saberia descrever o consumidor de tilápia que compra nas suas lojas?

\section{APÊNDICE II - Questionário - Consumidor final}

\section{Pesquisa - consumo de tilápia no estado de São Paulo}

Esta pesquisa faz parte de um estudo realizado pela FZEA/USP no programa de mestrado profissional Gestão e Inovação na Indústria Animal. A proposta deste trabalho é estudar o mercado da tilápia para o consumidor final no Estado de São Paulo. Para tanto, gostaria de contar com a sua participação respondendo às perguntas abaixo (tempo aproximado: 5 minutos). Para responder leve em consideração os seus comportamentos, preferências e expectativas de consumo. Lembre-se que para participar você precisa morar no Estado de São Paulo (escopo desta pesquisa).

Desde já agradeço a sua contribuição para os resultados deste trabalho.

\section{Débora}

Você mora no estado de São Paulo? *

$\begin{array}{lll}- & \text { Sim } \\ - & C & \text { Não }\end{array}$

Em qual cidade você mora? *

\section{Qual sua idade?*}

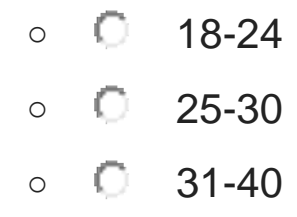


$\begin{array}{lll}\circ & \text { C } & 40-50 \\ & C & 50 \text { ou mais } \\ & \text { Qual a faixa de renda bruta da sua } \\ & C & \text { até } 2 \text { salários mínimos } \\ & - & \text { de } 2 \text { a } 4 \text { salários mínimos } \\ - & \text { de } 4 \text { a } 10 \text { salários mínimos } \\ - & \text { de } 10 \text { a } 20 \text { salários mínimos } \\ & - & \text { acima de } 20 \text { salários mínimos }\end{array}$

Qual proteína animal você mais consome nas suas refeições? *

- $\mathrm{B}$ Bovina

- C Suína

- $\mathrm{F}$ Frango

- $\mathrm{P}$ Peixes e frutos do mar

- $C$ Outro:

Desta, qual a quantidade que consome semanalmente? *

Dica: 1 filé de peito ou bife = aprox. $100 \mathrm{~g}$

- $C$ Menos de $100 \mathrm{~g}$

- C $100 \mathrm{~g}-200 \mathrm{~g}$

- C $200 \mathrm{~g}-300 \mathrm{~g}$

- C $300 \mathrm{~g}-400 \mathrm{~g}$

- $\quad$ acima de $400 \mathrm{~g}$

Quanto você pagou no $\mathrm{kg}$ desta proteína na última vez que você comprou? *

- $\mathrm{R} \$ 1,00-\mathrm{R} \$ 10,00$

- $\mathrm{R} \$ 10,00-\mathrm{R} \$ 20,00$

- C $R \$ 20,00-R \$ 30,00$

- $\mathrm{R} \$ 30,00$ ou mais

- C Não lembro

Qual proteína animal você prefere consumir? *

- C Bovina

- C Suína

$\circ$ Frango 
- $C$ Peixes e frutos do mar

- C Outro:

Por quê? *

- Г Gosto do sabor

- 「 É fácil de preparar

- Г Tem um preço acessível

- $\square$ Encontro com facilidade nos supermercados

- Г Confio na qualidade do produto/fabricante

- Г É mais saudável

- Г Outro:

Você consome tilápia? *

- $C \mathrm{Sim}$

- C Não

Por que você come tilápia? *

(selecione todos os motivos que forem compatíveis)

- Г Procuro ter uma alimentação saudável e balanceada

○ Г Não como carne vermelha

- $\Gamma$ Tem sabor suave

○ Г Não tem espinhos

- $\quad$ Acho prático de preparar

- ᄃ É fácil de encontrar para comprar

- Г Outro:

Quanto você consome de tilápia semanalmente? *

Dica: 1 filé = aprox. $100 \mathrm{~g}$
- C Menos de $100 \mathrm{~g}$
- C $100 \mathrm{~g}-200 \mathrm{~g}$
- C $200 \mathrm{~g}-300 \mathrm{~g}$
- C 300g-400g
- $C$ acima de $400 \mathrm{~g}$

Por quais motivos você não consome mais tilápia? *

(pode ser um ou mais motivos) 
- ᄃ Não encontro produto aonde faço compras

- ᄃ Acho difícil preparar

- ᄃ O preço é elevado comparado com outras proteínas

- ᄃ A quantidade que eu como já é suficiente

- ᄃ Não tenho o hábito de comprar

- ᄃ Não há esta opção nos restaurantes que eu frequento

- $\square$ Outro:

Aonde você compra tilápia? *

(pode ser mais de um lugar)

- Г Peixaria

- $\square$ Supermercado

- ᄃ Direto com o produtor

- $ᄃ$ Pesque-pague

- ᄃ Feira

- $\square$ Açougue

- Outro:

Se você fosse ao supermercado com a intenção de comprar tilápia e não encontrasse, o que faria? Compraria: *

- C Carne Bovina

- C Carne Suína

- $\mathrm{C}$ Frango

- C Outro peixe ou frutos do mar

- $C$ Outro:

Se a sua resposta anterior foi "outro peixe ou frutos do mar", por qual ou quais espécies de peixe você substitui a compra da tilápia?

○ ᄃ Salmão

- ᄃ Merluza

- ᄃ Polaca do Alasca

- $\square$ Sardinha

- ᄃ Pescada

- $\ulcorner$ Panga

- $ᄃ$ Outro:

Quando você compra tilápia, normalmente ela é: * 


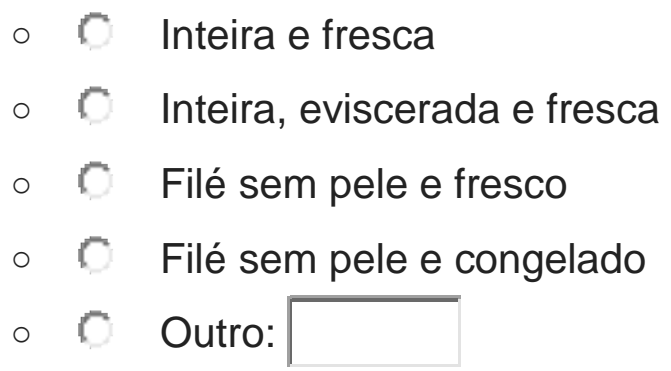

Quanto você pagou no $\mathrm{kg}$ da tilápia na última vez que você comprou? *

$\begin{array}{lll}\circ & \mathrm{R} & \mathrm{R} \$ 1,00-\mathrm{R} \$ 10,00 \\ \circ & \mathrm{C} & \mathrm{R} \$ 10,00-\mathrm{R} \$ 20,00 \\ \circ & \mathrm{C} & \mathrm{R} \$ 20,00-\mathrm{R} \$ 30,00 \\ \circ & \mathrm{C} & \mathrm{R} \$ 30,00 \text { ou mais } \\ \circ & \mathrm{C} & \mathrm{Não} \text { lembro }\end{array}$

Se o $\mathrm{kg}$ do preço da tilápia fosse igual ao preço do $\mathrm{kg}$ da proteína que você prefere, você substituiria a compra por tilápia? *

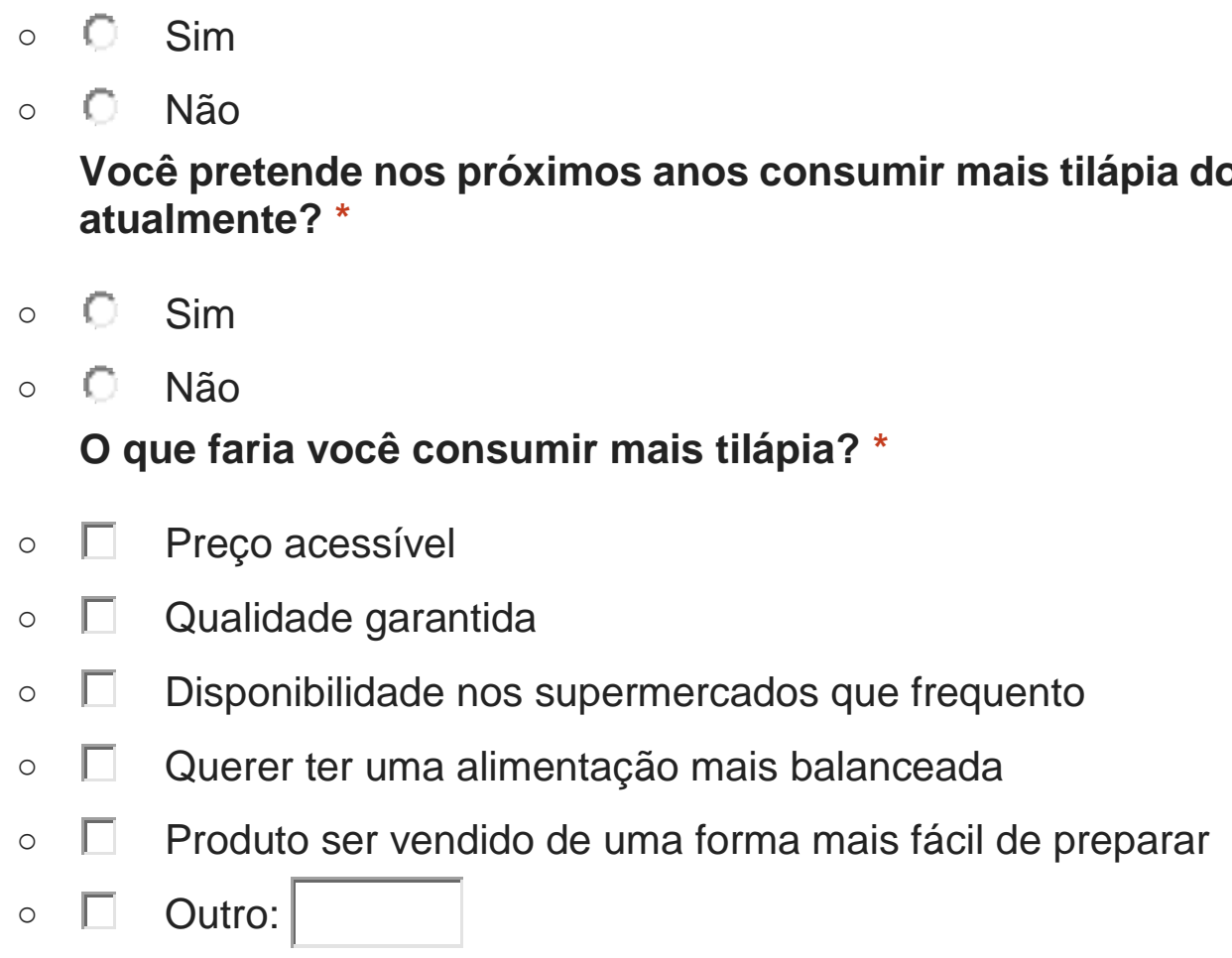




\section{Referências}

\section{1ํANUÁRIO BRASILEIRO DE PESCA E AQUICULTURA. 2014}

2 ONGRESSO MUNDIAL DE TILÁPIA. 2013. Os supermercados como principal canal de distribuição. Por Meg Felippe, Rio de Janeiro. 2013.

Angelini, M.F.C.; Savay-da-Silva, L. K., Oetterer, M. Minced e surimi de tilápia congelados atraem consumidor. Visão Agrícola, Piracicaba, v.8, v.11, p.118-119, JulDez 2012.

Asche, F., A. G. Guttormsen, T. Sebulonsen; E. H. Sissener, 2005, Competition between farmed and wild salmon: the Japanese salmon market: Agricultural Economics, v. 33, p. 333-340.

Asche, F., K. H. Roll, H. N. Sandvold, A. Sørvig; D. Zhang, 2013, Salmon aquaculture: Larger companies and increased production: Aquaculture Economics ; Management, v. 17, p. 322-339.

Asche, F., and T. Bjorndal, 2011, The economics of salmon aquaculture, v. 10, John Wiley \& Sons.

Bell, F.W. 1968. The Pope and the Price of Fish. American Economic Review 63:134650.

CARLTON, D. W., PERLOFF, J.M. Modern industrial organization. New York. 2nd ed. 973p. 1994.

Coase, R. H. (1972). "Industrial Organization: a proposal for research". The firm, The Market and The Law. The University of Chicago Press, 1988, parte III, p. 57-74.

Costa Nogueira, S., 2008, O Sistema Agroindustrial de Tilápias na Região Noroeste do Estado de São Paulo: características das transações e formas de coordenação.

DAYAN, A. 2004. Les études de marché. Paris: Presses Universitaires de France, 2004. $127 \mathrm{p}$

Duan, Z.-h., L.-n. Jiang, J.-I. Wang, X.-y. Yu, T. Wang, 2011, Drying and quality characteristics of tilapia fish fillets dried with hot air-microwave heating: Food and Bioproducts processing, v. 89, p. 472-476.

Embrapa, Reaproveitamento de resíduos sólidos na cadeia agroindustrial do pescado. Julho, 2013.

Fabinyi, M., 2012, Historical, cultural and social perspectives on luxury seafood consumption in China: Environmental Conservation, v. 39, p. 83-92. 
FARINA, E.M.M.Q. Reflexões sobre desregulamentação e sistemas agroindustriais: a experiência brasileira. 1996. 156p. Tese (Livre-Doc encia). Universidade de São Paulo. São Paulo, 1996.

FAO. Fish to 2030 - Prospects for fisheries and aquaculture, 2013. Disponível em: http://www.fao.org/docrep/019/i3640e/i3640e.pdf. Acesso em Out. 2014.

FAO. The State of World Fisheries and Aquaculture 2014. Disponível em: http://www.fao.org/3/a-i3720e.pdf. Acesso em: Jun.2014.

FERGUSON, C. E. "Microeconomia, Ed." Forense, Rio de Janeiro: 20ª Edição(1999). Cap. 4, p. 103-145

Ferraz de Arruda, L.; Borghesi, R.; Oetterer, M. Aproveitamento de resíduos reduz desperdícios e poluição ambiental. Visão Agrícola, Piracicaba, v.8, n.11, p.150-151, Jul-Dez 2012.

FIGUEIREDO JÚNIOR CA, VALENTE JÚNIOR AS. Cultivo de tilápia no Brasil: origens e cenário atual. In: Congresso da Sociedade Brasileira de Economia, Administração e Sociologia Rural. 2008; 41. Rio Branco.

FROTA, I. L. N. Desenvolvimento regional por meio dos clusters: o caso da indústria do camarão no nordeste. In: SIMPÓSIO DE ENGENHARIA E PRODUÇÃO, 13., 2006. Bauru. Anais... Bauru: UNESP, Brasil, 2006.

GIL, C. A. Métodos e técnicas de pesquisa social. 6. ed. São Paulo: Editora Atlas, 2009. 200 p.

GLOBEFISH. FAO Fisheries and Aquaculture Department. Disponível em: http://www.agmrc.org/commodities_products/aquaculture/tilapia-profile/. Acesso em: Abr.2015. (a)

GLOBEFISH. FAO Fisheries and Aquaculture Department. Disponível em: http://www.globefish.org/tilapia-dec-2014.html. Acesso em: Abr.2015. (b)

Graddy, K., 2006, Markets: the Fulton fish market: The Journal of Economic Perspectives, p. 207-220.

GRAY, D. E. Pesquisa no mundo real. 2. ed. Porto Alegre: Penso, 2012. 488 p.

HEINHUIS, L.; NIKOLIK, G. The rise of the aquatic chicken. Rabobank Industry Note. v.471. 6p. 2015.

Igarashi, M. A., J. M. Penafort, and R. A. L. De Souza, Aspectos básicos do desenvolvimento da aqüicultura no Brasil. PUBVET, v. 3, n. 3, 2009.

Jory, D., C. Alceste; T. Cabrera, 2000, Mercado y comercialización de tilapia en los Estados Unidos de Norteamérica: Panorama Acuícola, v. 5. 
Kite-Powell, H. L., M. C. Rubino; B. Morehead, 2013, THE FUTURE OF US SEAFOOD SUPPLY: Aquaculture Economics ; Management, v. 17, p. 228-250.

KOTLER, P., KELLER, K. L. Administração de marketing: Tradução Mônica Rosenberg, Brasil Ramos Fernandes, Cláudia Freire. 12. Ed. Pearson Prentice Hall. São Paulo, 2006.

KUBITZA, F. Com a palavra os consumidores. Panorama da Aquicultura, v. 69, p. 48$53,2002$.

Kupfer, D., Hasenclever L. Economia industrial: fundamentos teóricos e práticas no Brasil. 2ed. Rio de Janeiro: Elsevier, 2013.

MANKIW, N. G.. As forças de mercado da oferta e da demanda. In: Introdução à economia. São Paulo: Cengage Learning, 2008. p. 63-75.

MANKIW, L., 2010, NG Introdução à economia: Tradução da $5^{\mathbf{a}}$ edição norte americana. São Paulo: Cengage Learning.

MARSHALL, A. Princípios de economia: tratado introdutório/Alfred Marshall; tradução revista Rômulo Almeida e Ottolmy Strauch. 1985.

MELO, G.; NIKOLIK, G. Brazilian Aquaculture - a Seafood Industry Giant in the Making. Rabobank Industry Note. v.362. 11p. 2013.

Melo, Jose Fernando Bibiano, Andre Sampaio dos Santos, and Alvoneide Assis Damasceno. "COMERCIALIZAÇÃO E PERFIL DO CONSUMIDOR DA CARNE DE PEIXE NA REGIÃO DO SEMIÁRIDO DE JUAZEIRO (BA) E PETROLINA (PE)." 2011.

Melo, Givaldo Oliveira, et al. "BIODIESEL DE ÓLEO DE PEIXE UMA ALTERNATIVA PARA REGIÕES SEMI-ÁRIDAS." Embrapa Algodão-Artigo em anais de congresso (ALICE). In: CONGRESSO BRASILEIRO DE MAMONA, 4.; SIMPÓSIO INTERNACIONAL DE OLEAGINOSAS ENERGÉTICAS, 1., 2010, João Pessoa. Inclusão social e energia: anais. Campina Grande: Embrapa Algodão, 2010.

MPA. Ministério da Pesca e Aquicultura. Boletim Estatístico de Pesca e Aquicultura $2010 . \quad$ Disponível em: http://www.mpa.gov.br/images/Docs/Informacoes e Estatisticas/Boletim\%20Estat\% C3\%ADstico\%20MPA\%202010.pdf. Acesso em: abr. 2013

MPA. Ministério da Pesca e Aquicultura. Boletim Estatístico de Pesca e Aquicultura $2011 . \quad$ Disponível em: http://www.mpa.gov.br/images/Docs/Informacoes e Estatisticas/Boletim\%20MPA\%2 02011FINAL.pdf. Acesso em: Jun.2014.

NETO, A. P. R. Fatores que influenciam na decisão de compra de pescado nas feiras livres de Macapá AP. 2010. 38 f. Monografia (TCC em Extensão Pesqueira). Coordenação do Curso de Engenharia de Pesca, Universidade do Estado do Amapá, 2010 
NOGUEIRA, S. C. O sistema agroindustrial de tilápias na região noroeste no Estado de São Paulo: características das transações e formas de coordenação. 2008. 138p. Tese (Doutorado). Universidade Federal Rural do Rio de Janeiro. Rio de Janeiro, 2008.

Norman-López, A.,T. Bjørndal, 2009, Is tilapia the same product worldwide or are markets segmented?: Aquaculture Economics ; Management, v. 13, p. 138-154.

OETTERER, M. Tecnologias emergentes para 0 processamento do pescado. Universidade de São Paulo. Escola Superior de Agricultura Luiz de Queiroz. Piracicaba- SP (2006).

Oetterer, M.; Savay-da-Silva, L. K., Galvão, J. A. Tecnologias emergentes prolongam características do pescado in natura. Visão Agrícola, Piracicaba, v.8, n.11, p.142-144, Jul-Dez 2012.

Oglend, A., 2013, Recent trends in salmon price volatility: Aquaculture Economics ; Management, v. 17, p. 281-299.

Oken, E., A. L. Choi, M. R. Karagas, K. Mariën, C. M. Rheinberger, R. Schoeny, E. Sunderland, S. Korrick, 2012, Which fish should I eat? Perspectives influencing fish consumption choices: Environmental health perspectives, v. 120, p. 790.

Osaki, M., 2003, Determinantes da oferta e da demanda por cebola argentina no Brasil nos anos 90, Universidade de São Paulo.

OSTRENSKY, A.; BORGHETTI, J. R.; SOTO, D. (EDITORES). Estudo setorial para consolidação de uma aquicultura sustentável no Brasil. FAO/SEAP, Curitiba, 2007. $279 p$.

PASSOS, C. R. M; NOGAMI, Noções Gerais de Economia; Demanda, Oferta e Equilíbrio de Mercado. In: O. Princípios de Economia. 5 ed. rev. Cencage Learning, 2011 , p. $10-17,75-96$

Peavey, S.; Work, T.; Riley, J. Consumer Attitudes Toward Fresh and Frozen Fish. Journal of aquatic food product technology. Volume 3, Number 2, p. 71-87. 1994.

PEREIRA, M.; TELLES, E.; DIAS, R.; BALIAN, S. Descrição do sistema agroindustrial brasileiro de pescado. Tese (Mestrado) Faculdade de Medicina Veterinária e Zootecnia - Universidade de São Paulo. Pirassununga, 2010.

Piedade, B. M. R., S. H. F. Silva, 2002, Income-elasticity of poultry meat consumption in metropolitan areas of Brazil: Scientia Agricola.

Portal Brasil. Sistema Nacional de Preços ao Consumidor (INPC/IBGE). Disponível em: http://www.portalbrasil.net/inpc.htm. Acesso em: Mai.2015

Raupp, F. M., I. M. Beuren, 2003, Metodologia da pesquisa aplicável às ciências sociais: Como elaborar trabalhos monográficos em contabilidade: teoria e prática, v. 3, p. 76-97. 
ROSSETTI, J. P. O Mercado: Conceito, Tipologia e Estruturas. In: Introdução à economia. Editora Atlas. 17ª edição (1997). São Paulo. Cap. 8. p. 395-428.

SAMPIERI, R. H.; COLLADO, C. F.; LUCIO, P. B. Metodologia de pesquisa. 3. ed. São Paulo: McGraw-Hill, 2006. 583 p.

Scherer, F. M. (1990) Industrial Market Structure and Economic Performance. USA: Houghton Mifflin Company, 2a ed.

Scherer, F.M. \& Ross, D. (1990) Industrial Market Structure and Economic Performance. USA: Houghton Mifflin Company.

SILVA, NAPIE GALVÊ ARAÚJO, et al. "Avaliação socioeconômica e mercadológica da tilapicultura brasileira: o projeto produtivo Curupati-Peixe." Congresso da Sociedade Brasileira de Economia, Administração e Sociologia Rural. Vol. 45. 2007.

Soares, N. S., M. L. da Silva, S. R. Valverde, J. E. de Lima, U. R. de Souza, 2009, Análise do mercado brasileiro de celulose, 1969-2005: Revista Árvore, v. 33, p. 563573.

Sonoda, D. Y., 2002, Análise econômica de sistemas alternativos de produção de tilápias em tanques rede para diferentes mercados, Universidade de São Paulo.

Souza Barros, M., M. E. B. Junqueira, M. N. de Camargo, V. d. P. M. Figueiredo, W. P. de Camargo Filho; D. D. NetÇi, MERCADO VAREJISTA DE GÉNEROS ALIMENTICIOS DA GRANDE SAO PAULO-UMA ABORDAGEM ESTRUTURAL. Brasil, 1978.

Sussel, F. R. Tilapicultura no Brasil e Entraves na Produção. Agência Paulista de Tecnologia dos Agronegócios. 6p. Pirassununga, 2013.

Sussel, F. R. Criação de tilápias cresce vigorosamente no Brasil. Agência Paulista de Tecnologia dos Agronegócios. Pirassununga, 2011a. 5p.

. Tilapicultura no estado de São Paulo. Agência Paulista de Tecnologia dos Agronegócios, Pirassununga, 2011b. 4p.

Tofanelli, M. B., M. Fernandes, O. B. Martins Filho, N. S. Carrijo, 2007, Mercado de hortaliças frescas no município de Mineiros-GO: Horticultura Brasileira, v. 25, p. 475478.

SCHLICKMANN, F. Estudo das relações entre os produtores e comercializadores da carcinicultura na região de Laguna e grande Florianópolis. 2008, 76 p. Dissertação (Mestrado) - Universidade Federal de Santa Catarina, Florianópolis, 2008

SHY, O. Industrial Organization: theory and applications. The MIT Press, London, 1995. P.169-186.

Tavares, G. C. Aquino, R. M. A., Palhares, M. M., Santos, R. R. D., Bonfim, L. M., Teixeira, L.V., PERFIL DO CONSUMO DE PESCADO NA CIDADE DE BELO 
HORIZONTE, MG. 2013, Universidade Federal de Minas Gerais (EV-UFMG). Belo Horizonte, MG.

TURRA, E.M. et al. Aquacultura Brasileira: o foco disperso em muitas espécies. PUBVET, Londrina, V. 3, N. 27, Ed. 88, Art. 632, 2009

USDA. United States Department of Agriculture Economic Research Service. Disponível em: http://www.ers.usda.gov/dataproducts/aquaculture-data.aspx\#.U-Dwx2PZcwl. Acesso em: Abr.2015

Vannuccini, S., 2001, Global markets for tilapia: INFOFISH INTERNATIONAL, p. 1621.

VARIAN, H. R., 2006, Microeconomia-princípios básicos, Elsevier Brasil.

VASCONCELLOS, M. A. d. S.; D. B. PINHO, 2002, Manual de economia: Equipe de Professores da USP. Cap. 2, p. 101-134.

VIAN, C. E. de Freitas, 2009, Introdução à Economia. Ed. Alínea, Campinas. Cap. 5, p. 97-118.

Vidotti, Rose Meire. "TECNOLOGIAS PARA O APROVEITAMENTO INTEGRAL DE PEIXES." Curso Técnica de Manejo em Piscicultura Intensiva, n. 01, p. 01-22.Macapá, 2011.

Vieira, V. A., 2002, As tipologias, variações e características da pesquisa de marketing: Revista da FAE, Curitiba, v. 5, p. 61-70.

WILDE, O. Elementos Básicos de Oferta e Demanda. In: NORDHAUS, W. D.;

SAMUELSON, P. A. Economia. Rio de janeiro: McGraw-Hill, 2006. cap 3, p. 37-50.

Zylbersztajn, D. Economia das Organizações (capítulo 2). In.: Zylbersztajn, D.; Neves, M.F. (org.) Economia e Gestão dos Negócios Agroalimentares. São Paulo: Pioneira, 2000.

Zimmermann, S., 2010, Recent developments of the tilapia production in Latin America and commercialization and market potentials: Revista Colombiana de Ciencias Pecuarias, v. 21, p. 465-466. 